




FOUR STAGES OF

GREEK RELIGION 



\section{FOUR STAGES OF}

\section{GREEK RELIGION}

STUDIES BASED ON A COURSE OF LECTURES

DELIVERED IN APRIL 1912

AT COLUMBIA UNIVERSITY

\section{BY \\ GILBERT MURRAY}

REGIUS PROFESSOR OF GREEK IN THE UNIVERSITY OF OXFORD

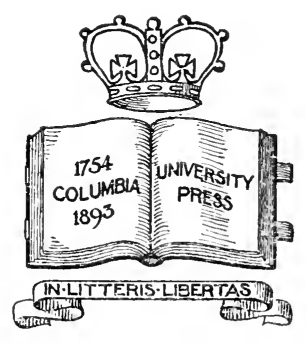

NEW YORK

COLUMBIA UNIVERSITY PRESS 
PRINTED BY HORACE HART M.A. AT THE CLARENDON PRESS OXFORD, ENGLAND 


\section{PREFACE}

This small book has taken a long time in growing. Though the first two essays were only put in writing this year for a course of lectures which I had the honour of delivering at Columbia University, the third, which was also used at Columbia, had in its main features appeared in the Hibbert Fournal in I9ro, the fourth in part in the English Review in 1908 ; the translation of Sallustius was made in 1907 for use with a small class at Oxford. Much of the material is much older in conception, and all has been reconsidered. I must thank the editors of both the above-named periodicals for their kind permission to reprint.

I think it was the writings of my friend Mr. Andrew Lang that first awoke me, in my undergraduate days, to the importance of anthropology and primitive religion to a Greek scholar. Certainly I began then to feel that the great works of the ancient Greek imagination are penetrated habitually by religious conceptions and postulates which literary scholars like myself had not observed or understood. In the meantime the situation has changed. Greek religion is being studied right and left, and has revealed itself 
as a surprisingly rich and attractive, though somewhat controversial, subject. It used to be a deserted territory; now it is at least a battle-ground. If ever the present differences resolved themselves into a simple fight with shillelaghs between the scholars and the anthropologists, I should without doubt wield my reluctant weapon on the side of the scholars. Scholarship is the rarer, harder, iess popular and perhaps the more permanently valuable work, and it certainly stands more in need of defence at the moment. But in the meantime I can hardly understand how the purest of ' pure scholars' can fail to feel his knowledge enriched by the savants who have compelled us to dig below the surface of our classical tradition and to realize the imaginative and historical problems which so often lie concealed beneath the smooth security of a verbal 'construe'. My own essays do not for a moment claim to speak with authority on a subject which is still changing and showing new facets year by year. They only claim to represent the way of regarding certain large issues of Greek Religion which has gradually taken shape, and has proved practically helpful and consistent with facts, in the mind of a very constant, though unsystematic, reader of many various periods of Greek literature.

In the first essay my debt to Miss Harrison is great and obvious. My statement of one or two points is 
probably different from hers, but in the main I follow her lead. And in either case I cannot adequately describe the advantage I have derived from many years of frequent discussion and comparison of results with a Hellenist whose learning and originality of mind are only equalled by her vivid generosity towards her fellow-workers.

The second may also be said to have grown out of Miss Harrison's writings. She has by now made the title of 'Olympian' almost a term of reproach, and thrown down so many a scornful challenge to the canonical gods of Greece, that I have ventured on this attempt to explain their historical origin and plead for their religious value. When the essay was already written I read Mr. Chadwick's impressive book on The Heroic Age (Cambridge, I912), and was delighted to find in an author whose standpoint and equipment are so different from mine so much that confirmed or clarified my own view.

The title of the third essay I owe to a conversation with Professor J. B. Bury. We were discussing the change that took place in Greek thought between, say, Plato and the Neo-Platonists, or even between Aristotle and Posidonius, and which is seen at its highest power in the Gnostics. I had been calling it a rise of asceticism, or mysticism, or religious passion, or the like, when my friend corrected me. 'It is not 
a rise; it is a fall or failure of something, a sort of failure of nerve.'-We are treading here upon somewhat firmer ground than in the first two essays. The field for mere conjecture is less: we are supported more continuously by explicit documents. Yet the subject is a very difficult one owing to the scattered and chaotic nature of the sources, and even where we get away from fragments and reconstructions and reach definite treatises with or without authors' names, I cannot pretend to feel anything like the same clearness about the true meaning of a passage in Philo or the Corpus Hermeticum that one normally feels in a writer of the classical period. Consequently in this essay I think I have hugged my modern authorities rather close, and seldom expressed an opinion for which I could not find some fairly authoritative backing, my debt being particularly great to Reitzenstein, Bousset, and the brilliant Hellenistiscb-Römiscbe Kultur of P. Wendland. I must also thank my old pupil, Mr. Edwyn Bevan, who was kind enough to read this book in proof, for some valuable criticisms. The subject is one of such extraordinary interest that I offer no apology for calling further attention to it.

A word or two about the last brief revival of the ancient religion under 'Julian the Apostate' forms the natural close to this series of studies. But here our material, both historical and literary, is so abundant 
that I have followed a different method. After a short historical introduction I have translated in full a very curious and little-known ancient text, which may be said to constitute something like an authoritative Pagan creed. Some readers may regret that I do not give the Greek as well as the English. I am reluctant, however, to publish a text which I have not examined in the MSS., and I feel also that, while an edition of Sallustius is rather urgently needed, it ought to be an edition with a full commentary.

I was first led to these studies by the wish to fill up certain puzzling blanks of ignorance in my own mind, and doubtless the little book bears marks of this origin. It aims largely at the filling of interstices. It avoids the great illuminated places, and gives its mind to the stretches of intervening twilight. It deals little with the harvest of flowers or fruit, but watches the inconspicuous seasons when the soil is beginning to stir, the seeds are falling or ripening.

G. M. 



\section{CONTEN'TS}

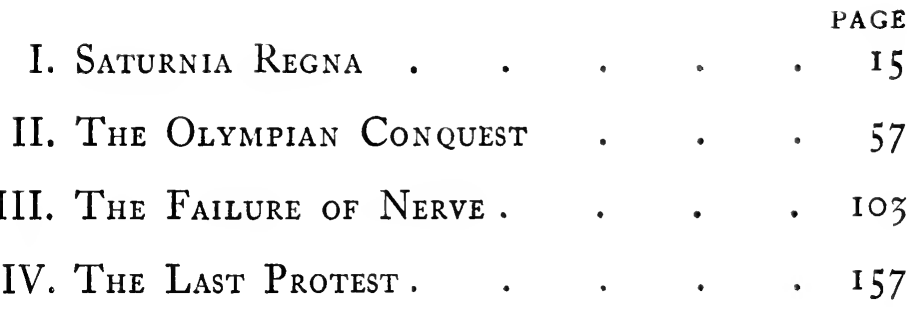

Appendix: Translation of the Treatise of Sallustius, $\pi \epsilon \rho \grave{\imath} \Theta \epsilon \hat{\omega} \nu$ каi Kó $\sigma \mu o v$. . $\quad$ I87

INDEX . . . . . . . 215 


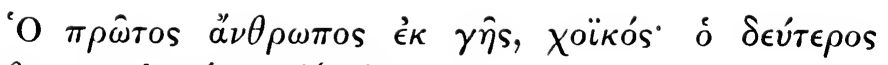

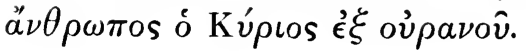

'The first man is of the earth, earthy; the second man is the Lord from heaven.' 


\section{I}

SATURNIA REGNA 



\section{I \\ SATURNIA REGNA}

Many persons who are quite prepared to admit the importance to the world of Greek poetry, Greek art, and Greek philosophy, may still feel it rather a paradox to be told that Greek religion specially repays our study at the present day. Greek religion, associated with a romantic, trivial, and not very edifying mythology, has generally seemed one of the weakest spots in the armour of those giants of the old world. Yet I will venture to make for Greek religion almost as great a claim as for the thought and the literature, not only because the whole mass of it is shot through by those strange lights of feeling and imagination, and the details of it constantly wrought into beauty by that instinctive sense of artistic form, which we specially associate with Classical Greece, but also for two definite historical reasons. In the first place, the student of that dark and fascinating department of the human mind which we may call Religious Origins, will find in Greece an extraordinary mass of material belonging to a very early date. For detail and variety the primitive Greek evidence has no equal. And, secondly, in this department as in others, ancient Greece has the triumphant if tragic distinction of beginning at the very bottom and struggling, however 
precariously, to the very summits. There is hardly any horror of primitive superstition of which we cannot find some distant traces in our Greek record. There is hardly any height of spiritual thought attained in the world that has not its archetype or its echo in the stretch of Greek literature that lies between Thales and St. Paul.

The progress of Greek religion falls naturally into three stages, all of them historically important. First there is the primitive Euetheia or Age of Ignorance, before Zeus came to trouble men's minds, a stage to which our anthropologists and explorers have found parallels in every part of the world. Dr. Preuss applies to it the charming word 'Urdummheit', or 'Primal Stupidity'. In some ways characteristically Greek, in others it is so typical of similar stages of thought elsewhere that one is tempted to regard it as the normal beginning of all religion, or almost as the normal raw material out of which religion is made. There is certainly some repulsiveness, but I confess that to me there is also an element of fascination in the study of these 'beastly devices of the heathen', at any rate as they appear in early Greece, where each single 'beastly device' as it passes is somehow touched with beauty and transformed by some spirit of upward striving.

Secondly there is the Olympian or classical stage, a stage in which, for good or ill, blunderingly or successfully, this primitive vagueness was reduced to a kirid of order. This is the stage of the great Olympian gods, who dominated art and poetry, ruled the 
imagination of Rome, and extended a kind of romantic dominion even over the Middle Ages. It is the stage that we know from the statues and the hand-books of mythology. Brilliant critics have said that this Olympian stage has value only as art and not as religion. That is just one of the points into which we shall inquire.

Thirdly there is the Hellenistic period, reaching roughly from Plato to St. Paul or the earlier Gnostics, a period based on the consciousness of manifold failure, and consequently touched both with morbidness and with that spiritual exaltation which is so often the companion of morbidness. It had behind it the failure of the Olympian theology, the failure of the free city-state, now crushed by semi-barbarous military monarchies; it lived through the gradual realization of two other failures-the failure of human government, even when backed by the power of Rome or the wealth of Egypt, to achieve a good life for man; and lastly the failure of the great propaganda of Hellenism, in which the long-drawn effort of Greece to educate a corrupt and barbaric world seemed only to lead to the corruption or barbarization of the very ideals which it sought to spread. This sense of failure, this progressive loss of hope in the world, in sober calculation, and in organized human effort, threw the later Greek back upon his own soul, upon emotion, upon the pursuit of personal holiness, upon emotions mysteries and revelations, upon the comparative neglect of this transitory and imperfect life for the sake of some dream-world far off, which shall subsist without sin or corruption, the same 
yesterday, to-day, and for ever. These three are the really significant and formative periods of Greek religious thought; but we may well cast our eyes also on a fourth stage, not historically influential perhaps, but at least romantic and interesting and worthy of considerable respect, when the old religion in the time of Julian roused itself for a last spiritual protest against the all-conquering ' atheism' of the Christians. The tendencies of the third stage are here accentuated by an increased demand for definite dogma and a still deeper consciousness of worldly defeat.

I shall not start with any definition of religion. Religion, like poetry and most other living things, cannot be defined. But some description of it perhaps may be useful, or at least some characteristic marks. In the first place, religion essentially deals with the uncharted region of human experience. A large part of human life has been thoroughly surveyed and explored; we understand the causes at work; and we are not bewildered by the problems. That is the domain of positive knowledge. But all round us on every side there is an uncharted region, just fragments of the fringe of it explored, and those imperfectly; it is with this that religion deals. And secondly we may note that religion deals with its own province not tentatively, by the normal methods of patient intellectual research, but directly, and by methods of emotion or sub-conscious apprehension. Agriculture, for instance, used to be entirely a question of religion; now it is almost entirely a question of science. In antiquity, if a field was barren, 
the owner of it would probably assume that the barrenness was due to 'pollution', or offence somewhere. He would run through all his own possible offences, or at any rate those of his neighbours and ancestors, and when he eventually decided the cause of the trouble, the steps that he would take would all be of a kind calculated not to affect the chemical constitution of the soil, but to satisfy his own emotions of guilt and terror, or the imaginary emotions of the imaginary being he had offended. A modern man in the same predicament would probably not think of religion at all, at any rate in the earlier stages; he would say it was a case for deeper ploughing or for basic slag. Later on, if disaster followed disaster till he began to feel himself a marked man, even the average modern would, I think, begin instinctively to reflect upon his sins. A third characteristic flows from the first. The uncharted region surrounds us on every side and is apparently infinite; consequently, when once the things of the uncharted region are admitted as factors in our ordinary conduct of life they are apt to be infinite factors, overruling and swamping all others. The thing that religion forbids is a thing never to be done; not all the inducements that this life can offer weigh at all in the balance. Indeed there is no balance. The man who makes terms with his conscience is essentially non-religious; the religious man knows that it will profit him nothing if he gain all this finite world and lose his stake in the infinite and eternal. ${ }^{1}$

1 Professor Émile Durkheim in his famous analysis of the religious emotions argues that when a man feels the belief and the command 
Am I going to draw no distinction then between religion and mere superstition? Not at present. Later on we may perhaps see some way to it. Superstition is the name given to a low or bad form of religion, to the kind of religion we disapprove. The line of division, if we made one, would be only an arbitrary bar thrust across a highly complex and continuous process.

Does this amount to an implication that all the as something coming from without, superior, authoritative, of infinite import, it is because religion is the work of the tribe and, as such, superior to the individual. The voice of God is the imagined voice of the whole tribe, heard or imagined by him who is going to break its laws. I have some difficulty about the psychology implied in this doctrine : surely the apparent externality of the religious command seems to belong to a fairly common type of experience, in which the personality is divided, so that first one part of it and then another emerges into consciousness. If you forget an engagement, sometimes your peace is disturbed for quite a long time by a vague external annoyance or condemnation, which at last grows to be a distinct judgement-- Heavens! I ought to be at the Committee on So-andso.' But apart from this criticism, there is obviously much historical truth in Professor Durkheim's theory, and it is not so different as it seems at first sight from the ordinary beliefs of religious men. The tribe to primitive man is not a mere group of human beings. It is his whole world. The savage who is breaking the laws of his tribe has all his world-totems, tabus, earth, sky and all-against him. He cannot be at peace with God.

The position of the hero or martyr who defies his tribe for the sake of what he thinks the truth or the right can easily be thought out on these lines. If you take the tribe as merely the human group it presents difficulties.

See Durkheim, 'Les Formes élémentaires de la vie religieuse,' in Travaux de l'Année Sociologique, 19I2; or G. Davy, 'La Sociologie de M. Durkheim,' in Rev. Philosopbique, xxxvi, pp. 42-71 and 160-85. 
religions that have existed in the world are false? Not so. It is obvious indeed that most, if analysed into intellectual beliefs, are false; and I suppose that a thoroughly orthodox member of any one of the million religious bodies that exist in the world must be clear in his mind that the other million minus one are wrong, if not wickedly wrong. That, I think, we must be clear about. Yet the fact remains that man must have some relation towards the uncharted, the mysterious, tracts of life which surround him on every side. And for my own part I am content to say that his method must be to a large extent very much what St. Paul calls $\pi i \sigma \tau \iota s$ or faith: that is, some attitude not of the conscious intellect but of the whole being, using all its powers of sensitiveness, all its feeblest and most inarticulate feelers and tentacles, in the effort somehow to touch by these that which cannot be grasped by the definite senses or analysed by the conscious reason. What we gain thus is an insecure but a precious possession. We gain no dogma, at least no safe dogma, but we gain much more. We gain something hard to define, which lies at the heart not only of religion, but of art and poetry and all the higher strivings of human emotion. I believe that at times we actually gain practical guidance in some questions where experience and argument fail. ${ }^{1}$ That

1 I suspect that most reforms pass through this stage. A man somehow feels clear that some new course is, for him, right, though he cannot marshal the arguments convincingly in favour of it, and may even admit that the weight of obvious evidence is on the other side. We read of judges in the seventeenth century who 
is a great work left for religion, but we must always remember two things about it: first, that the liability to error is enormous, indeed almost infinite; and second, that the results of confident error are very terrible. Probably throughout history the worst things ever done in the world on a large scale by decent people have been done in the name of religion, and I do not think that has entirely ceased to be true at the present day. All the Middle Ages held the strange and, to our judgement, the obviously insane belief that the normal result of religious error was eternal punishment. And yet by the crimes to which that false belief led them they almost proved the truth of something very like it. The record of early Christian and mediaeval persecutions which were the direct result of that one confident religious error comes curiously near to one's conception of the wickedness of the damned.

To turn to our immediate subject, I wish to put forward here what is still a rather new and unauthorized view of the development of Greek religion; readers will

believed that witches ought to be burned and that the persons before them were witches, and yet would not burn them-evidently under the influence of vague half-realized feelings. I know a vegetarian who thinks that, as far as he can see, carnivorous habits are not bad for human health and actually tend to increase the happiness of the species of animals eaten-as the adoption of Swift's Modest Proposal would doubtless relieve the economic troubles of the human race, and yet feels clear that for him the ordinary flesh meal (or 'rejoicing over corpses') would 'partake of the nature of sin'. The path of progress is paved with inconsistencies, though it would be an error to imagine that the people who habitually reject any higher promptings that come to them are really any more consistent. 
forgive me if, in treating so vast a subject, I draw my outline very broadly, leaving out many qualifications, and quoting only a fragment of the evidence.

The things that have misled us moderns in our efforts towards understanding the primitive stage in Greek religion, have been first the widespread and almost ineradicable error of treating Homer as primitive, and more generally our unconscious insistence on starting with the notion of 'Gods'. Mr. Hartland, in his address as president of one of the sections of the recent International Congress of Religions at Oxford, ${ }^{1}$ dwelt on the significant fact about savage religions that wherever the word ' God' is used our trustiest witnesses tend to contradict one another. Among the best observers of the Arunta tribes, for instance, some hold that they have no conception of God, others that they are constantly thinking about God. The truth is that this idea of a god far away in the sky-I do not say merely a First Cause who is "without body parts or passions', but almost any being that we should naturally call a ' god'-is an idea not easy for primitive man to grasp. It is a subtle and rarefied idea, saturated with ages of philosophy and speculation. And we must always remember that one of the chief religions of the world, Buddhism, has risen to great moral and intellectual heights without using the conception of God at all ; in his stead it has Dharma, the Eternal Law. ${ }^{2}$

Apart from some few philosophers, both Christian and Moslem, the gods of the ordinary man have as

1 Transactions of the Third International Congress of Religions, Oxford, 1908, pp. 26-7. $\quad 2$ The Buddhist Dharma, by Mrs. Rhys Davids. 
a rule been as a matter of course anthropomorphic. Men did not take the trouble to try to conceive them otherwise. In many cases they have had the actual bodily shape of man; in almost all they have possessed-of course in their highest developmenthis mind and reason and his mental attributes. It causes most of us even now something of a shock to be told by a mediaeval Arab philosopher that to call God benevolent or righteous or io predicate of him any other human quality is just as Pagan and degraded as to say that he has a beard. ${ }^{1}$ Now the Greek gods seem at first sight quite particularly solid and anthropomorphic. The statues and vases speak clearly, and they are mostly borne out by the literature. Of course we must discount the kind of evidence that misled Winckelmann, the mere Roman and Alexandrian art and mythology; but even if we go back to the fifth century B. c. we shall find the ruling conceptions far nobler indeed, but still anthropomorphic. We find firmly established the Olympian patriarchal family, Zeus the Father of gods and men, his wife Hera, his son Apollo, his daughter Athena, his brothers Poseidon and Hades, and the rest. We probably think of each figure more or less as like a statue, a habit of mind obviously wrong and indeed absurd, as if one thought of ' Labour' and ' Grief' as statues because Rodin or St. Gaudens has so represented them. And yet it was a habit into which the late Greeks themselves sometimes fell; ${ }^{2}$ their arts of

1 See Die Mutaziliten, oder die Freidenker im Islam, von H. Steiner. 1865.

2 Cf. E. Reisch, Entstebung und $W$ andel griecbischer Göttergestalten. Vienna, 1909. 
sculpture and painting as applied to religion had been so dangerously successful: they sharpened and made vivid an anthropomorphism which in its origin had been mostly the result of normal human laziness. The process of making winds and rivers into anthropomorphic gods is, for the most part, not the result of using the imagination with special vigour. It is the result of not doing so. The wind is obviously alive; any fool can see that. Being alive, it blows; how? why, naturally; just as you and I blow. It knocks things down, it shouts and dances, it whispers and talks. And, unless we are going to make a great effort of the imagination and try to realize, like a scientific man, just what really happens, we naturally assume that it does these things in the normal way, in the only way we know. Even when you worship a beast or a stone, you practically anthropomorphize it. It happens indeed to have a perfectly clear shape, so you accept that. But it talks, acts, and fights just like a man-as you can see from the Australian Folk Tales published by Mrs. Langloh Parker-because you do not take the trouble to think out any other way of behaving. This kind of anthropomorphism-or as Mr. Gladstone used to call it, 'anthropophuism'-' humanity of nature'-is primitive and inevitable: the sharp-cut statue type of god is different, and is due in Greece directly to the work of the artists.

We must get back behind these gods of the artist's workshop and the romance-maker's imagination, and see if the religious thinkers of the great period use, or imply, the same highly human conceptions. We shall find Parmenides telling us that God is One, and coin- 
cides with the universe, which is a sphere and immovable ${ }^{1}$ Xenophanes, that God is all-seeing, all-hearing, and all mind; ${ }^{2}$ and as for his supposed human shape, why, if bulls and lions were to speak about God they would doubtless tell us that he was a bull or a lion. ${ }^{3}$ We must notice the instinctive language of the poets, using the word $\theta$ cós in many subtle senses for which our word 'God' is too stiff, too personal, and too anthropomorphic. Tò $\epsilon \dot{v} \tau v \chi \epsilon \hat{\imath} \nu$, ' the fact of success,'

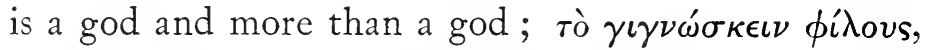
' to recognize a friend' after long absence, is a 'god'; wine is a 'god' whose body is poured out in libation to gods; and in the unwritten law of the human conscience 'a great god liveth and groweth not old'. You will say that is mere poetry or philosophy: it represents a particular theory or a particular metaphor. I think not. Language of this sort is used widely and without any explanation or apology. It was evidently understood and felt to be natural by the audience. If it is metaphorical, all metaphors have grown from the

1 Parm. Fr. 8, 3-7 (Diels $\left.{ }^{2}\right)$.

2 Xen. Fr. 24 (Diels $\left.{ }^{2}\right)$.

${ }^{3}$ Xen. Fr 15.

${ }^{4}$ Aesch. Cho. 60; Eur. Hel. 560; Bac. 284; Soph. O.T. 871 .

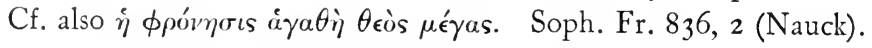

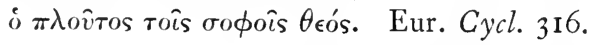

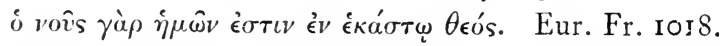

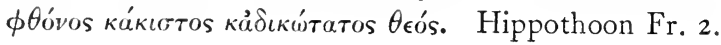

A certain moment of time...

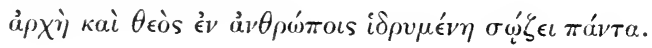

Pl. Leg. $775 \mathrm{E}$.

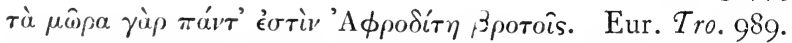

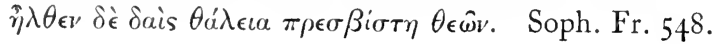


soil of current thought and normal experience. And without going into the point at length I think we may safely conclude that the soil from which such language as this grew was not any system of clear-cut personal anthropomorphic theology. No doubt any of these poets, if he had to make a picture of one of these utterly formless Gods, would have given him a human form. That was the recognized symbol, as a veiled woman is St. Gaudens's symbol for ' Grief'.

But we have other evidence too which shows abundantly that these Olympian gods are not primary, but are imposed upon a background strangely unlike themselves. For a long time their luminous figures dazzled our eyes; we were not able to see the half-lit regions behind them, the dark primaeval tangle of desires and fears and dreams from which they drew their vitality. The surest test to apply in this question is the evidence of actual cult. Miss Harrison has here shown us the right method, and following her we will begin with the three great festivals of Athens, the Diasia, the Thesmophoria, and the Anthesteria. ${ }^{1}$

The Diasia was said to be the chief festival of Zeus, the central figure of the Olympians, though our authorities generally add an epithet to him, and call him Zeus Meilichios, Zeus of Placation. A god with an 'epithet' is always suspicious, like a human being with an 'alias'. Miss Harrison's examination

1 See J. E. Harrison, Prolegomena, i. ii, iv; Mommsen, Feste der Stadt Athen, I898, pp. 308-22 (Thesmophoria), 384-404 (Anthesteria), 42I-6 (Diasia). See also Pauly-Wissowa, s.v. 
(Prolegomena, pp. $28 \mathrm{ff}$.) shows that in the rites Zeus has no place at all. Meilichios from the beginning has a fairly secure one. On some of the reliefs Meilichios appears not as a god, but as an enormous bearded snake, a well-known representation of underworld powers or dead ancestors. Sometimes the great snake is alone; sometimes he rises gigantic above the small human worshippers approaching him. And then, in certain reliefs, his old barbaric presence vanishes, and we have instead a benevolent and human father of gods and men, trying, as Miss Harrison somewhere expresses it, to look as if he had been there all the time.

There was a sacrifice at the Diasia, but it was not a sacrifice given to Zeus. To Zeus and all the heavenly gods men gave sacrifice in the form of a feast, in which the god had his portion and the worshippers theirs. The two parties cemented their friendship and feasted happily together. But the sacrifice at the Diasia was a holocaust : ${ }^{1}$ every shred of the victim was burnt to ashes, that no man might partake of it. We know quite well the meaning of that form of sacrifice: it is a sacrifice to placate or appease the powers below, the Chthonioi, the dead and the lords of death. It was performed, as our authorities tell us, $\mu \epsilon \tau \grave{\alpha} \sigma \tau v \gamma \nu o^{-}$

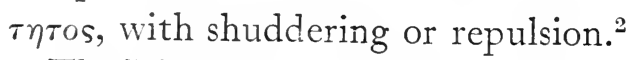

The Diasia was a ritual of placation, that is, of casting away various elements of pollution or danger and appeasing the unknown wraths of the surrounding darkness. The nearest approach to a god contained

1 Prolegomena, p. $15 \mathrm{f}$.

2 Luc. Icaro-Menippos 24 schol. ad loc. 
not a substantive personal goddess, but merely a personification of the ritual itself : an imaginary charm-bearer generated by so much Charm-bearing, just as Meilichios in the Diasia was generated from the ritual of Appeasement.

Now the Diasia were dominated by a sacred snake. Is there any similar divine animal in the Thesmophoria? Alas, yes. Both here, and still more markedly in the mysteries of Demeter and Persephone at Eleusis, we regularly find the most lovely of all goddesses, Demeter and Persephone, habitually-I will not say represented by, but dangerously associated with, a sacred Sow. A Pig is the one animal in Greek religion that actually had sacrifice made to it. ${ }^{1}$

The third feast, the Anthesteria, belongs in classical times to the Olympian Dionysus, and is said to be the oldest of his feasts. On the surface there is a touch of the wine-god, and he is given due official prominence; but as soon as we penetrate anywhere near the heart of the festival, Dionysus and his brother gods are quite forgotten, and all that remains is a great ritual for appeasing the dead. All the days of the Feast were nefasti, of ill omen; the first day especially was és $\tau$ ò

Dual from Greek. I accept provisionally the derivation of these $\theta_{\epsilon \sigma} \mu o^{\prime}$ from $\theta \epsilon \sigma$ in $\theta_{\epsilon}^{\prime} \sigma \sigma \alpha \sigma \sigma \theta a l, \theta_{\epsilon}^{\prime} \sigma \phi a \tau o s, \theta_{\epsilon}^{\prime} \sigma \kappa \epsilon \lambda o s, \pi o \lambda v^{\prime} \theta \epsilon \sigma \tau o s, a \dot{a} \pi o^{-}$

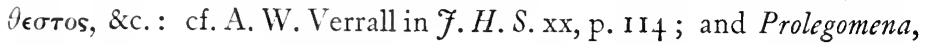
pp. $48 \mathrm{ff} .,{ }_{3} 6 \mathrm{f}$. But, whatever the derivation, the Thesmoi were the objects carried.

${ }^{1}$ Frazer, Golden Bough, ii. +4 ff. ; A. B. Cook, F. H. S. xiv, pp. 153t; J. E. Harrison, Themis, p. 5. See also A. Lang, Homeric Hymns, I 899, p. 63. 
Basileus or Sacred King, and the imaginary god. ${ }^{1}$ Whatever reality there ever was in the ceremony has apparently by classical times faded away. But the place where the god received his bride is curious. It was called the Boukolion, or Bull's Shed. It was not originally the home of an anthropomorphic god, but of a divine animal.

Thus in each of these great festivals we find that the Olympian gods vanish away, and we are left with three things only: first, with an atmosphere of religious fear; second, with a whole sequence of magical ceremonies which, in two at least of the three cases, ${ }^{2}$ produce a kind of strange personal emanation of themselves,

1 Dr. Frazer, The Magic Art, ii. I37, thinks it not certain that the rixpos took place during the Anthesteria, at the same time as the oath of the $\gamma$ epaipai. Without the $\gamma \alpha \dot{\alpha} \mu \circ$, however, it is hard to see what the $\beta a \sigma i \lambda \iota v v a$ and $\gamma \in$ equpai had to do in the festival; and this is the view of Mommsen, Feste der Stadt Athen, pp. 39I-3; Gruppe in Iwan Müller, Mytbologie und Religionsgeschichte, i. 33 ; Farnell, Cults, v. 2 I7.

${ }^{2}$ One might perhaps say, in all three. 'A $v \theta i \sigma \tau \eta \rho \circ$ sov̂ $\Pi v \theta 0 \chi \rho \eta \sigma \tau o \hat{v}$ rovvóv is the name of a society of worshippers in the island of Thera, I. G. I. iii. 329. This gives a god Anthister, who is clearly identified with Dionysus, and seems to be a projection of a feast Anthisteria $=$ Anthesteria. The inscription is of the second century B.c. and it seems likely that Anthister-Anthisteria, with their clear derivation from

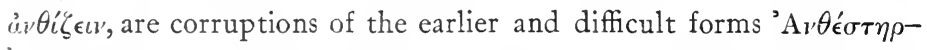
'A $v \theta \epsilon \sigma \tau$ p pıa. It is noteworthy that Thera, an island lying rather outside the main channels of civilization, kept up throughout its history a tendency to treat the 'epithet' as a full person. Hikesios and Koures come very early; also Polieus and Stoichaios without the name Zeus; Delphinios, Karneios, Aiglatas, and Aguieus without Apollo.

See Hiller von Gaertringen in the Festscbrift fïr O. Benndorf, p. 228. Also Nilsson, Griechische Feste, I906, p. 267, n. 5. 
the Appeasements producing Meilichios, the Charmbearings Thesmophoros; and thirdly, with a divine or sacred animal. In the Diasia we find the old superhuman snake, who reappears so ubiquitously throughout Greece, the regular symbol of the underworld powers, especially the hero or dead ancestor. Why the snake was so chosen we can only surmise. He obviously lived underground : his home was among the Chthonioi, the Earth-People. Also, says the Scholiast to Aristophanes (Plut. 533), he was a type of new birth because he throws off his old skin and renews himself. And if that in itself is not enough to show his supernatural power, what normal earthly being could send his enemies to death by one little pin-prick, as some snakes can?

In the Thesmophoria we found sacred swine, and the reason given by the ancients is no doubt the right one. The sow is sacred because of its fertility, and possibly as practical people we should add, because of its cheapness. Swine are always prominent in Greek agricultural rites. And the bull? Well, we modern towndwellers have almost forgotten what a real bull is like. For so many centuries we have tamed him and penned him in, and utterly deposed him from his place as lord of the forest. The bull was the chief of magic or sacred animals in Greece, chief because of his enormous strength, his rage, in fine his mana, as anthropologists call it ; that fine primitive word which comprises force, vitality, prestige, holiness, and power of magic, and which may belong equally to a lion, a chief, a medicineman, or a battle-axe.

Now in the art and the hand-books these sacred P. P. 648 
animals have all been adopted into the Olympian system. They appear regularly as the 'attributes' of particular gods. Zeus is merely accompanied by a snake, an eagle, a bull, or at worst assumes for his private purposes the forms of those animals. The cow and the cuckoo are sacred to Hera; the owl and the snake to Athena; the dolphin, the crow, the lizard, the bull, to Apollo. Dionysus, always like a wilder and less middleaged Zeus, appears freely as a snake, bull, he-goat, and lion. Allowing for some isolated exceptions, the safest rule in all these cases is that the attribute is original and the god is added. ${ }^{1}$ It comes out very clearly in the case of the snake and the bull. The tremendous mana of the wild bull indeed occupies almost half the stage of pre-Olympian ritual. The religion unearthed by Dr. Evans in Crete is permeated by the bull of Minos. The heads and horns are in almost every sacred room and on every altar. The great religious scene depicted on the sarcophagus of Hagia Triada ${ }^{2}$ centres in the holy blood that flows from the neck of a captive and dying bull. Down into classical times bull's blood was a sacred thing which it was dangerous to touch and death to taste: to drink a cup of it was the most heroic form of suicide. ${ }^{3}$ The sacrificial bull at Delphi was

${ }^{1}$ Miss Harrison, 'Bird and Pillar Worship in relation to Ouranian Divinities,' Transactions of the Third International Congress for the History of Religion, Oxford, 1908, vol. ii, p. 154; Farnell, Greece and Babylon, I9I I, pp. $66 \mathrm{ff}$.

2 First published by R. Paribeni, 'Il Sarcofago dipinto di Hagia Triada,' in Momumenti antichi della $R$. Accademia dei Lincei, xix, Igo8, p. 6, T. i-iii. See also Themis, pp. 158 ff.

${ }^{3}$ Ar. Equites, 82-4-or possibly of apotheosis. See Themis, p. I 54, n. 2. 
called Hosiotêr: he was not merely bosios, holy; he was Hosiotêr, the Sanctifier, He who maketh Holy. It was by contact with him that holiness was spread to others. On a coin and a vase, cited by Miss Harrison, ${ }^{1}$ we have a bull entering a holy cave and a bull standing in a shrine. We have holy pillars whose holiness consists in the fact that they have been touched with the blood of a bull. We have a long record of a bull-ritual at Magnesia, ${ }^{2}$ in which Zeus, though he makes a kind of external claim to be lord of the feast, dare not claim that the bull is sacrificed to him. Zeus has a ram to himself and stands apart, showing but a weak and shadowy figure beside the original Holy One. We have immense masses of evidence about the religion of Mithras, at one time the most serious rival of Christianity, which sought its hope and its salvation in the blood of a divine bull.

Now what is the origin of this conception of the sacred animal? The origin was discovered and explained with almost prophetic insight by Dr. Robertson Smith. ${ }^{3}$ The origin is what he calls a sacramental feast: you eat the flesh and drink the blood of the divine animal in order-here I diverge from Robertson Smith's language-to get into you his mana, his vital power. The classical instance is the sacramental eating of a camel by an Arab tribe, recorded in the

1 Themis, p. 145, fig. 25 ; and p. I52, fig. 28 b.

2 O. Kern, Inscbriften v. Magnesia, No. 98, discussed by O. Kern, Arch. Anz. 1894, p. 78, and Nilsson, Griechische Feste, p. 23.

3 Religion of the Semites, I901, p. $33^{8}$; Reuterskiold, in Arcbiv f. Relig. xv. I-23. 
works of St. Nilus. ${ }^{1}$ The camel was devoured on a particular day at the rising of the morning star. $\mathrm{He}$ was cut to pieces alive, and every fragment of him had to be consumed before the sun rose. If the life had once gone out of the flesh and blood the sacrifice would have been spoilt; it was the spirit, the vitality, of the camel that his tribesmen wanted. The only serious error that later students have found in Robertson Smith's statement is that he spoke too definitely of the sacrifice as affording communion with the tribal god. There was no god there, only the raw material out of which gods are made. You devoured the holy animal to get its mana, its swiftness, its strength, its great endurance, just as the savage now will eat his enemy's brain or heart or hands to get some particular quality residing there. The imagination of the preHellenic tribes was evidently dominated above all things by the bull, though there were other sacramental feasts too, combined with sundry horrible rendings and drinkings of raw blood. It is strange to think that even small things like kids and fawns and hares should have struck primitive man as having some uncanny vitality which he longed for, or at least some uncanny power over the weather or the crops. Yet to him it no doubt appeared obvious. Frogs, for instance, could always bring rain by croaking for it.

Here comes a difficulty. If the Olympian god was not there to start with, how did he originate? We can understand-at least after a course of anthropology-

1 Nili Opera, Narrat. iii. 28. 
this desire of primitive man to acquire for himself the superhuman forces of the bull; but how does he make the transition from the real animal to the imaginary human god ? First let us remember the innate tendency of primitive man everywhere, and not especially in Greece, to imagine a personal cause, like himself in all points not otherwise specified, for every striking phenomenon. If the wind blows it is because some being more or less human, though of course superhuman, is blowing with his cheeks. If a tree is struck by lightning it is because some one has thrown his battle-axe at it. In some Australian tribes there is no belief in natural death. If a man dies it is because ' bad man kill that fellow'. St. Paul, we may remember, passionately summoned the heathen to refrain from worshipping $\tau \dot{\eta} \nu \kappa \tau i \sigma \iota \nu$, the creation, and go back to $\tau \grave{o} \nu \kappa \tau i \sigma a \nu \tau \alpha$, the creator, human and masculine. It was as a rule a road that they were only too ready to travel.

But this tendency was helped by a second factor. Research has shown us the existence in early Mediterranean religion of a peculiar transitional step, a man wearing the head or skin of a holy beast. The Egyptian gods are depicted as men with beasts' heads: that is, the best authorities tell us, their shapes are derived from the kings and priests who on great occasions of sacrifice covered their heads with a beastmask. ${ }^{1}$ Minos, with his projection the Minotaur, was

1 Lang, Myth, Ritual, and Religion, 1906, ii. 284; ibid. 130; Moret, Caractère religieux de la Monarcbie Égyptienne; Dieterich, Mitbrasliturgie, 1903. 
a bull-god and wore a bull-mask. From early Island gems, from a fresco at Mycenae, from Assyrian reliefs, Mr. A. B. Cook has collected many examples of this mixed figure-a man wearing the protomê, or mask and mane, of a beast. Sometimes we can actually see him offering libations. Sometimes the worshipper has become so closely identified with his divine beast that he is represented not as a mere man wearing the protomê of a lion or bull, but actually as a lion or bull wearing the protomê of another. ${ }^{1}$ Hera, $\beta$ ôे $\pi \iota s$, with a cow's head; Athena, $\gamma \lambda \alpha v \kappa \hat{\omega} \pi \iota s$, with an owl's head, or bearing on her breast the head of the Gorgon; Heracles clad in a lion's skin and covering his brow $\delta \epsilon \iota \nu \hat{\omega}$

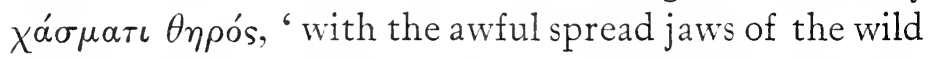
beast,' belong to the same class. So does the Dadouchos at Eleusis and other initiators who let candidates for purification set one foot-one only and that the lefton the skin of a sacrificial ram, and called the skin $\Delta$ ios $\kappa \hat{\omega} a s$, the fleece not of a ram, but of Zeus. ${ }^{2}$

The mana of the slain beast is in the hide and head and blood and fur, and the man who wants to be in thorough contact with the divinity gets inside the skin and wraps himself deep in it. He begins by being a man wearing a lion's skin : he ends, as we have seen, by feeling himself to be a lion wearing a lion's skin. And who is this man? He may on particular occasions

1 A. B. Cook in F. H. S. I894, 'Animal Worship in the Mycenaean Age.' See also Hogarth on the 'Zakro Sealings', F.H.S. I902; these seals show a riot of fancy in the way of mixed monsters, starting in all probability from the simpler form. See the quotation from Robertson Smith in Hogarth, p. 9I. ${ }^{2}$ Feste der Stadt Athen, p. $4^{\mathrm{I}} 6$. 
be only a candidate for purification or initiation. But par excellence he who has the right is the priest, the medicine-man, the divine king. If an old suggestion of my own is right, he is the original $\theta$ cós or $\theta \epsilon \sigma o ́ s$, the incarnate medicine or spell or magic power. ${ }^{1}$ He at first, I suspect, is the only $\theta \epsilon o$ 's or 'God' that his society knows. We commonly speak of ancient kings being 'deified'; we regard the process as due to an outburst of superstition or insane flattery. And so no doubt it sometimes was, especially in later times-when man and god were felt as two utterly distinct things. But 'deification' is an unintelligent and misleading word. What we call 'deification' is only the survival of this undifferentiated human $\theta$ єós, with his mana, his крázos and $\beta i^{\prime} \alpha$, his control of the weather, the rain and the thunder, the spring crops and the autumn floods; his knowledge of what was lawful and what was not, and his innate power to curse or to 'make dead'. Recent researchers have shown us in abundance the early Greek medicine-chiefs making thunder and lightning and rain. ${ }^{2}$ We have long known the king as possessor of Dike and Themis, of justice and tribal custom; we have known his effect on the fertility of the fields and the tribes, and the terrible results of a king's sin or a king's sickness. ${ }^{3}$

What is the subsequent history of this medicine-

1 Antbropology and the Classics, 1908, pp. 77, 78.

2 A. B. Cook, Class. Rev.xvii, pp. 275 ff.; A. J. Reinach, Rev. de l'H ist. des Religions, 1x, p. I78; S. Reinach, Cultes, Mythes, छ̋c., ii. 160-66.

3 One may suggest in passing that this explains the enormous families attributed to many sacred kings of Greek legend: why Priam 
chief or $\theta \epsilon$ ós? He is differentiated, as it were: the visible part of him becomes merely human; the supposed supernatural part grows into what we should call a God. The process is simple. Any particular medicine-man is bound to have his failures. As Dr. Frazer gently reminds us, every single pretension which he puts forth on every day of his life is a lie, and liable sooner or later to be found out. Doubtless men are tender to their own delusions. They do not at once condemn the medicine-chief as a fraudulent institution, but they tend gradually to say that he is not the real all-powerful $\theta \epsilon o ́ s . \quad H e$ is only his representative. The real $\theta \epsilon o ́ s$, tremendous, infallible, is somewhere far away, hidden in clouds perhaps, on the summit of some inaccessible mountain. If the mountain is once climbed the god will move to the upper sky. The medicinechief meanwhile stays on earth, still influential. $\mathrm{He}$ has some connexion with the great god more intimate than that of other men; at worst he possesses the god's

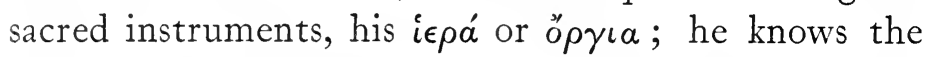
rules for approaching him and making prayers to him.

There is therefore a path open from the divine beast to the anthropomorphic god. From beings like Thesmophoros and Meilichios the road is of course much easier. They are already more than half anthropomorphic ; they only lack the concreteness, the lucid shape and the detailed personal history of the Olym-

or Danaus have their fifty children, and Heracles, most prolific of all, his several hundred. The particular numbers chosen, however, are probably due to other causes, e.g. the fifty moon-months of the Penteteris. 
pians. In this connexion we must not forget the power of hallucination, still fairly strong, as the history of religious revivals in America will bear witness, ${ }^{1}$ but far stronger, of course, among the impressionable hordes of early men. ' The god', says M. Doutté in his profound study of Algerian magic, 'c'est le désir collectif personnifié,' the collective desire projected, as it were, or personified. ${ }^{2}$ Think of the gods who have appeared in great crises of battle, created sometimes by the desperate desire of men who have for years prayed to them, and who are now at the last extremity for lack of their aid, sometimes by the confused and excited remembrances of the survivors after the victory. The gods who led the Roman charge at Lake Regillus, ${ }^{3}$ the gigantic figures that were seen fighting before the Greeks at Marathon, ${ }^{4}$ even the celestial signs that promised Constantine victory for the cross: ${ }^{5}$-these are the effects of great emotion : we can all understand them. But even in daily life primitive men seem to have dealt more freely than we generally do with apparitions and voices and daemons of every kind. One of the most remarkable and noteworthy sources for this kind of hallucinatory god in early societies is a social custom that we have almost forgotten, the religious Dance.

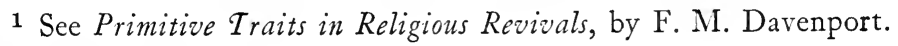
New York, 1906.

2 E. Doutté, Magie et religion dans l'Afrique du Nord, I909, p. 601.

3 Cicero, de Nat. Deorum, ii. 2 ; iii. 5, 6 ; Florus, ii. I2.

4 Plut. Theseus, 35 ; Paus. i. 32. 5. Herodotus only mentions a bearded and gigantic figure who struck Epizelos blind (vi. I I7).

${ }^{5}$ Eusebius, Vit. Constant., 1.i, cc. 28, 29, 30; Nazarius inter Panegyr. Vet. x. 14, I5. 
When the initiated young men of Crete or elsewhere danced at night over the mountains in the Oreibasia or Mountain Walk they not only did things that seemed beyond their ordinary workaday strength; they also felt themselves led on and on by some power which guided and sustained them. 'This daemon has no necessary' name : a man may be named after him 'Oreibasius', 'Belonging to the Mountain Dancer', just as others may be named 'Apollonius' or 'Dionysius'. The god is only the spirit of the Mountain Dance, Oreibates, though of course he is absorbed at different times in various Olympians. There is one god called Aphiktor, the Suppliant, He who prays for mercy. He is just the projection, as M. Doutte would say, of the intense emotion of one of those strange processions well known in the ancient world, bands of despairing men or women who have thrown away all means of self-defence and join together at some holy place in one passionate prayer for pity. The highest of all gods, Zeus, was the special patron of the suppliant; and it is strange and instructive to find that $Z$ eus the all-powerful is actually identified with this Aphiktor: Z $\epsilon \dot{v} s \mu \grave{\epsilon} \nu$

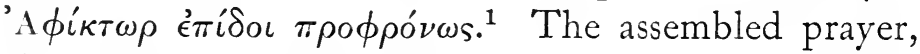
the united cry that rises from the oppressed of the world, is itself grown to be a god, and the greatest god. A similar projection arose from the dance of the Kouroi, or initiate youths, in the dithyramb-the magic dance which was to celebrate, or more properly, to

1 Aesch. Suppl. I, cf. 478, Zєis ikríp. Rise of the Greek Epic ${ }^{2}$, pp. 108,

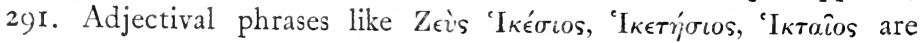
common and call for no remark. 
hasten and strengthen, the coming on of spring. That dance projected the Megistos Kouros, the greatest of youths, who is the incarnation of spring or the return of life, and lies at the back of so many of the most gracious shapes of the classical pantheon. The Kouros appears as Dionysus, as Apollo, as Hermes, as Ares: in our clearest and most detailed piece of evidence he actually appears with the characteristic history and attributes of Zeus. ${ }^{1}$

This spirit of the dance, who leads it or personifies its emotion, stands more clearly perhaps than any other daemon half-way between earth and heaven. A number of difficult passages in Euripides' Bacchae and other Dionysiac literature find their explanations when we realize how the god is in part merely identified with the inspired chief dancer, in part he is the intangible projected incarnation of the emotion of the dance.

'The collective desire personified:' on what does the collective desire, or collective dread, of the primitive community chiefly concentrate? On two things, the food-supply and the tribe-supply, the desire not to die of famine and not to be harried or conquered by the neighbouring tribe. The fertility of the earth and the fertility of the tribe, these two are felt in early religion as one. ${ }^{2}$ The earth is a mother: the human mother is an äpovpa, or ploughed field. Earth as she brings forth vegetation in spring is Kourotrophos, rearer of

1 Hymn of the Kouretes, Themis, passim.

2 See in general I. King, The Development of Religion, I910; E. J. Payne, History of the New World, 1892, p. 4I4. Also Dieterich, Muttererde, esp. pp. 37-58. 
Kouroi, or the young men of the tribe. The nymphs and rivers are all Kourotrophoi. The Moon is Kourotrophos. She quickens the young of the tribe in their mother's womb; at one terrible hour especially she is ' a lion to women' who have offended against her holiness. She also marks the seasons of sowing and ploughing, and the due time for the ripening of crops. When men learn to calculate in longer units, the Sun appears: they turn to the Sun for their calendar, and at all times of course the Sun has been a power in agriculture. He is not called Kourotrophos, but the Young Sun returning after winter is himself a Kouros, ${ }^{1}$ and all the Kouroi have some touch of the Sun in them. The Cretan Spring-song of the Kouretes

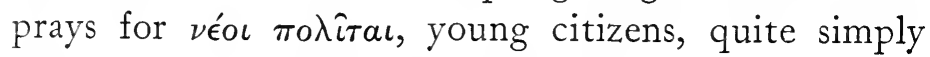
among the other gifts of the spring. ${ }^{2}$

This is best shown by the rites of tribal initiation, which seem normally to have formed part of the spring Drômena or sacred performances. The Kouroi, as we have said, are the initiated young men. They pass through their initiation; they become no longer $\pi a i \delta \epsilon \varsigma$, boys, but ă ${ }^{\prime} \delta \rho \epsilon s$, men. The actual name Kouros is possibly connected with $\kappa \epsilon i \rho \omega$, to shave, ${ }^{3}$ and may mean

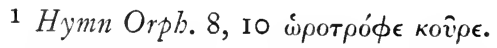

2 For the order in which men generally proceed in worship, turning their attention to (I) the momentary incidents of weather, rain, sunshine, thunder, \&c.; (2) the Moon; (3) the Sun and stars, see Payne, History of the New W orld called America, vol. i, p. 474, cited by Miss Harrison, Themis, p. 390.

${ }^{3}$ On the subject of Initiations see Webster, Primitive Secret Societies, New York, I908; Schurtz, Altersklassen und Männerbunde, Berlin, 1902 ; Van Gennep, Rites de Passage, Paris, 1909. Also Nilsson, 
that after this ceremony they first cut their long hair.

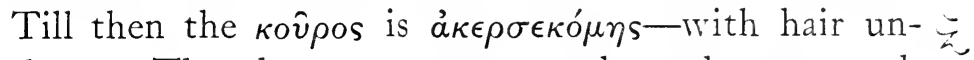
shorn. They have now open to them the two roads ak that belong to ä $\nu \delta \rho \in s$ alone: they have the work of begetting children for the tribe, and the work of killing the tribe's enemies in battle.

The classification of people according to their age is apt to be sharp and vivid in primitive communities. We, for example, think of an old man as a kind of man, and an old woman as a kind of woman; but in primitive peoples as soon as a man and woman cease to be able to perform his and her due tribal functions they cease

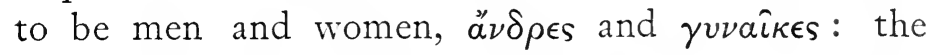
ex-man becomes a $\gamma \epsilon^{\prime} \rho \omega \nu$; the ex-roman a $\gamma \rho \alpha \hat{v} .^{1}$ We distinguish between 'boy' and 'man', between ' girl' and 'woman'; but apart from the various words for baby, Attic Greek would have four sharp

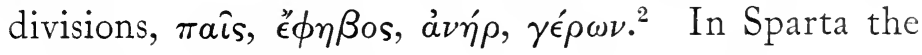
divisions are still sharper and more numerous, centreing in the great initiation ceremonies of the Iranes, or full-grown youths, to the goddess called Orthia or

Grundlage des Spartanischen Lebens in Klio xii (I9I2), pp. 308-40. The derivation from $\kappa \epsilon i \rho \omega$ is far from certain: see Themis, p. 337 , n. I.

1 Cf. Dr. Rivers on mate, 'Primitive Conception of Death,' Hibbert Fournal, January I912, p. 393.

2 Cf. Cardinal Virtues, Pindar, Nem. iii. 72 :

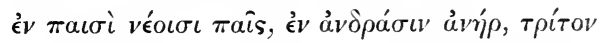

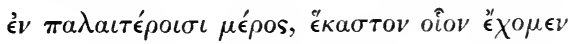

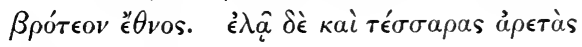

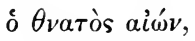

also Pindar, Pyth. iv. 28r. 
Bortheia. ${ }^{1}$ These initiation ceremonies are called Teletai, 'completions': they mark the great 'rite of transition' from the immature, charming, but half useless thing, which we call boy or girl, to the $\tau \epsilon \epsilon \epsilon \iota$ s $\alpha^{\prime} \nu \eta^{\prime} \rho$, the full member of the tribe as fighter or counsellor, or to the $\tau \epsilon \lambda \epsilon i a$ $\gamma v \nu \eta^{\prime}$, the full wife and mother. This whole subject of Greek initiation ceremonies calls pressingly for more investigation. It is only in the last few years that we have obtained the material for understanding them, and the whole mass of the evidence needs re-treatment. For one instance, it is clear that a great number of rites which were formerly explained as remnants of human sacrifice are simply ceremonies of initiation. ${ }^{2}$

At the great spring Drômenon the tribe and the growing earth were renovated together: the earth arises afresh from her dead seeds, the tribe from its dead ancestors; and the whole process, charged as it is with the emotion of pressing human desire, projects its anthropomorphic god or daemon. A vegetation-spirit we call him, very inadequately; he is a divine Kouros, a Year-Daemon, a spirit that in the first stage is living,

1 See Woodward in B.S. A. xiv, 83. Nikagoras won four (successive ?) victories as $\mu \iota \kappa \iota \chi \iota^{\zeta} \delta^{\prime} \mu \epsilon v_{0} s, \pi \rho o ́ \pi a \iota s, \pi a \hat{s}$, and $\mu \epsilon \lambda \lambda \epsilon i \rho \eta v$, i. e. from his tenth to fifteenth year. He would then at 14 or 15 become an iran. Plut. $L y c$. I 7 gives the age of an iran as 20. This agrees with the age of an "ै $\phi \beta$ os at Athens as 'I5-20', 'I4-2I', 'about I6'; see authorities in Stephanus s.v. "' $\phi \eta \beta$ os. Such variations in the date of 'puberty ceremonies' are common.

${ }^{2}$ See Rise of the Greek Epic, Appendix on Hym. Dem.; and W. R. Halliday, C. R. xxv, 8. Nilsson's valuable article has appeared since the above was written (see note $3, \mathrm{p} .44$ ). 
then dies with each year, then thirdly rises again from the dead, raising the whole dead world with him--the Greeks called him in this phase 'the Third One', or the 'Saviour'. The renovation ceremonies were accompanied by a casting off of the old year, the old garments, and everything that is polluted by the infection of death. And not only of death; but clearly I think, in spite of the protests of some Hellenists, of guilt or sin also. For the life of the Year-Daemon, as it seems to be reflected in Tragedy, is generally a story of Pride and Punishment. Each Year arrives, waxes great, commits the sin of Hubris, and then is slain. The death is deserved; but the slaying is a sin: hence comes the next Year as Avenger, or as the Wronged One re-risen : 'they all pay retribution for their injustice one to another according to the ordinance of time.' 1 It is this range of ideas, half suppressed during the classical period, but evidently still current among the ruder and less Hellenized peoples, which supplied St. Paul with some of his most famous and deep-reaching metaphors. 'Thou fool, that which thou sowest is not quickened except it die.' ' 'As He was raised from the dead we may walk with Him in newness of life.' And this renovation must be preceded by a casting out and killing of the old polluted life-' the old man in us must first be crucified.'

1 Anaximander apud Simplic. phys. 24, I3; Diels, Fragmente der Vorsokratiker, i, I3. See especially F. M. Cornford, From Religion to Pbilosophy (Cambridge, 1912), i; also my article on English and Greek Tragedy in Essays of the Oxford English School, 19I2. This explanation of the $\tau \rho i$ íos $\sigma \omega \tau \eta^{\prime} \rho$ is my conjecture.

2 I Cor. xv. 36; Rom. vi generally, 3-Ir. 
'The old man must be crucified.' We observed that in all the three Festivals there was a pervasive element of vague fear. Hitherto we have been dealing with early Greek religion chiefly from the point of view of mana, the positive power or force that man tries to acquire from his totem-animal or his god. But there is also a negative side to be considered : there is not only the mana, but the tabu, the Forbidden, the Thing Feared. We must cast away the old year; we must

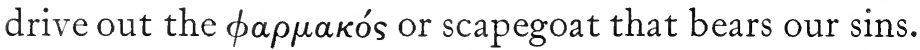
When the ghosts have returned and feasted with us at the Anthesteria we must with tar and branches of buckthorn purge them out of every corner of the rooms till the air is pure from the infection of death. We must avoid speaking dangerous words; in great moments we must avoid speaking any words at all, lest there should be even in the most innocent of them some unknown danger; for we are surrounded above and below by Kêres, or Spirits, winged influences, shapeless or of unknown shape, sometimes the spirits of death, sometimes of disease, madness, calamity; thousands and thousands of them, as Sarpedon says, from whom man can never escape nor hide ${ }^{1}$ ' all the air so crowded with them,' says an unknown ancient poet, ' that there is not one empty chink into which you could push the spike of a blade of corn.' 2

The extraordinary security of our modern life in

1 Il. M. $326 \mathrm{f}$.

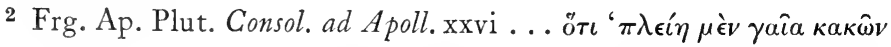

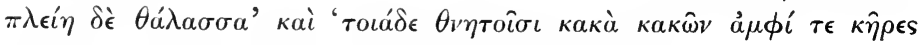

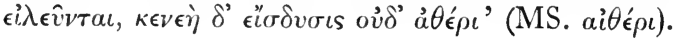


times of peace makes it hard for us to realize, except by a definite effort of the imagination, the constant precariousness, the frightful proximity of death, that was usual in these weak ancient communities. They were in fear of wild beasts; they were helpless against floods, helpless against pestilences. Their food depended on the crops of one tiny plot of ground ; and if the Saviour was not reborn with the spring, they slowly and miserably died. And all the while they knew almost nothing of the real causes that made crops succeed or fail. They only felt sure it was somehow a matter of pollution, of unexpiated defilement. It is this state of things that explains the curious cruelty of early agricultural works, the human sacrifices, the scapegoats, the tearing in pieces of living animals, and perhaps of living men, the steeping of the fields in blood. Like most cruelty it has its roots in terror, terror of the breach of $\mathcal{T} a b u$-the Forbidden Thing. I will not dwell on this side of the picture : it is well enough known. But we have to remember that, like so many morbid growths of the human mind, it has its sublime side. We must not forget that the human victims were often volunteers. The records of Carthage and Jerusalem, the long list in Greek legend of princes and princesses who died for their country, tell the same story. In most human societies, savage as well as civilized, it is not hard to find men who are ready to endure death for their fellow-citizens. We need not suppose that the martyrs were always the noblest of the human race. They were sometimes mad-hysterical or megalomaniac: sometimes reckless and desperate: 
sometimes, as in the curious case attested of the Roman armies on the Danube, they were men of strong desires and weak imagination ready to die at the end of a short period, if in the meantime they might glut all their senses with unlimited indulgence. ${ }^{\mathbf{1}}$

Still, when all is said, there is nothing that stirs men's imagination like the contemplation of martyrdom, and it is no wonder that the more emotional cults of antiquity vibrate with the worship of this dying Saviour, the Sôsipolis, the Sôtêr, who in so many forms dies with his world or for his world, and rises again as the world rises, triumphant through suffering over Death and the broken $\mathcal{T} a b u$.

$\tau a b u$ is at first sight a far more prominent element in the primitive religions than Mana, just as misfortune and crime are more highly coloured and striking than prosperity and decent behaviour. To an early Greek tribe the world of possible action was sharply divided between what was 'Themis and what was Not Themis, between lawful and tabu, holy and unholy, correct and forbidden. 'To do a thing that was not Themis was a sure source of public disaster. Consequently it was of the first necessity in a life full of such perils to find out the exact rules about them. How is that

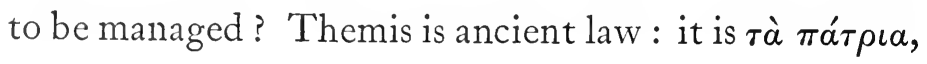

1 Frazer, Lectures on the Early History of the Kingsbip, 267; F. Cumont, 'Les Actes de S. Dasius,' in Analecta Bollandiana, xvi. 5-I6; cf. especially what St. Augustine says about the disreputable hordes of would-be martyrs, called Circumcelliones. See Index to Augustine, vol. xi in Migne: some passages collected in Seeck, Gesch. d. Untergangs der antiken $W$ elt, vol. iii, Anhang, pp. $503 \mathrm{ff}$. 
the way of our ancestors, the thing that has always been done and is therefore divinely right. In ordinary life, of course, Themis is clear. Every one knows it. But from time to time new emergencies arise, the like of which we have never seen, and they frighten us. We must go to the Gerontes, the Old Men of the Tribe; they will perhaps remember what our fathers did. What they tell us will be Presbiston, a word which

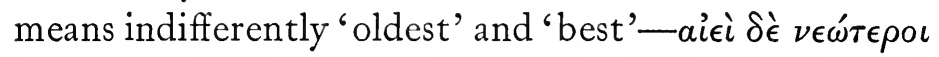

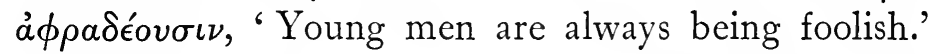
Of course, if there is a Basileus, a holy King, he by his special power may perhaps know best of all, though he too must take care not to gainsay the Old Men.

For the whole problem is to find out $\tau \dot{\alpha} \pi \alpha \dot{\tau} \rho \iota a$, the ways that our fathers followed. And suppose the Old Men themselves fail us, what must we needs do? Here we come to a famous and peculiar Greek custom, for which I have never seen quoted any exact parallel or any satisfactory explanation. If the Old Men fail us, we must go to those older still, go to our great ancestors, the "๊ $\rho \omega \epsilon$, the Chthonian people, lying in their sacred tombs, and ask them to help. The word $\chi \rho \hat{a} \nu$ means both 'to lend money' and 'to give an oracle', two ways of helping people in an emergency. Sometimes a tribe might happen to have a real ancestor buried in the neighbourhood; if so, his tomb would be an oracle. More often perhaps, for the memories of savage tribes are very precarious, there would be no well-recorded personal tomb. The oracle would be at some place sacred to the Chthonian people in general, or to some particular personification of them, a Delphi 
or a cave of 'Trophonios, a place of Snakes and Earth. You go to the Chthonian folk for guidance because they are themselves the Oldest of the Old Ones, and they know the real custom : they know what is Presbiston, what is Themis. And by an easy extension of this knowledge they are also supposed to know what is. He who knows the law fully to the uttermost also knows what will happen if the law is broken. It is, I think, important to realize that the normal reason for consulting an oracle was not to ask questions of fact. It was that some emergency had arisen in which men simply wanted to know how they ought to behave. The advice they received in this way varied from the virtuous to the abominable, as the religion itself varied. A great mass of oracles can be quoted enjoining the rules of customary morality, justice, honesty, piety, duty to a man's parents, to the old, and to the weak. But of necessity the oracles hated change and strangled the progress of knowledge. Also, like most manifestations of early religion, they throve upon human terror: the more blind the terror the stronger became their hold. In such an atmosphere the lowest and most beastlike elements of humanity tended to come to the front ; and religion no doubt as a rule joined with them in drowning the voice of criticism and of civilization, that is, of reason and of mercy. When really frightened the oracle generally fell back on some remedy full of pain and blood. The mediaeval plan of burning heretics alive had not yet been invented. But the history of uncivilized man, if it were written, would provide a vast list of victims, all of them innocent, who 
died or suffered to expiate some portent or monstrumsome reported $\tau$ '́pas-with which they had nothing whatever to do, which was in no way altered by their suffering, which probably never really happened at all, and if it did was of no consequence. The sins of the modern world in dealing with heretics and witches have perhaps been more gigantic than those of primitive men, but one can hardly rise from the record of these ancient observances without being haunted by the judgement of the Roman poet

Tantum religio potuit suadere malorum

and feeling with him that the lightening of this cloud, the taming of this blind dragon, must rank among the very greatest services that Hellenism wrought for mankind. 

II

'THE OLYMPIAN CONQUEST 



\section{II}

\section{THE OLYMPIAN CONQUEST}

\section{Origin of the Olympians}

The historian of early Greece must find himself often on the watch for a particular cardinal moment, generally impossible to date in time and sometimes hard even to define in terms of development, when the clear outline that we call Classical Greece begins to take shape out of the mist. It is the moment when, as Herodotus puts it, 'the Hellenic race was marked off from the barbarian, as more intelligent and more emancipated from silly nonsense.' ${ }^{1}$ In the eighth century в. с., for instance, so far as our remains indicate, there cannot have been much to show that the inhabitants of Attica and Boeotia and the Peloponnese were markedly superior to those of, say, Lycia or Phrygia, or even Epirus. By the middle of the fifth century the difference is enormous. On the one side is Hellas, on the other the motley tribes of 'barbaroi'.

When the change does come and is consciously felt we may notice a significant fact about it. It does

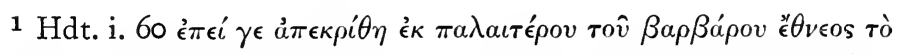

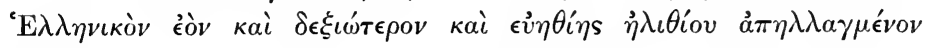
$\mu \hat{a} \lambda \lambda o v$. As to the date here suggested for the definite dawn of Hellenism Mr. Edwyn Bevan writes to me: 'I have often wondered what the reason is that about that time a new age began all over the world that we know. In Nearer Asia the old Semitic monarchies gave place to the Zoroastrian Aryans; in India it was the time of Buddha, in China of Confucius.' 
not announce itself as what it was, a new thing 'in the world. It professes to be a revival, or rather an emphatic realization, of something very old. The new spirit of classical Greece, with all its humanity, its intellectual life, its genius for poetry and art, describes itself merely as being 'Hellenic'-like the Hellenes. And the Hellenes were simply, as far as we can make out, much the same as the Achaioi, one of the many tribes of predatory Northnıen who had swept down on the Aegean kingdoms in the dawn of Greek history. ${ }^{1}$

This claim of a new thing to be old is, in varying degrees, a common characteristic of great movements. The Reformation professed to be a return to the Bible, the Evangelical movement in England a return to the Gospels, the High Church movement a return to the early Church. A large element even in the French Revolution, the greatest of all breaches with the past, had for its ideal a return to Roman republican virtue or to the simplicity of the natural man. ${ }^{2}$ I noticed quite lately a speech of an American Progressive leader claiming that his principles were simply those of Abraham Lincoln. The tendency is due in part to the almost insuperable difficulty of really inventing a new word to denote a new thing. It is so much easier to

1 On this subject in general see Ridgeway, Early Age of Greece, vol. i ; Leaf, Companion to Homer, Introduction; R.G.E. chap. ii ; and especially J. L. Myres, Dawn of History, chaps. viii and ix.

2 Since writing the above I find in Vandal, L'Avenement de Bonaparte, p. 20, in Nelson's edition, a phrase about the Revolutionary soldiers : 'Ils se modelaient sur ces Romains ... sur ces Spartiates ... et ils créaient un type de haute vertu guerrière, quand ils croyaient seulement le reproduire.' 
take an existing word, especially a famous word with fine associations, and twist it into a new sense. In part, no doubt, it comes from mankind's natural love for these old associations, and the fact that nearly all people who are worth much have in them some instinctive spirit of reverence. Even when striking out a new path they like to feel that they are following at least the spirit of one greater than themselves

The Hellenism of the sixth and fifth centuries was to a great extent what the Hellenism of later ages was almost entirely, an ideal and a standard of culture. The classical Greeks were not, strictly speaking, pure Hellenes by blood. Herodotus and Thucydides ${ }^{1}$ are quite clear about that. The original Hellenes were a particular conquering tribe of great prestige, which attracted the surrounding tribes to follow it, imitate it, and call themselves by its name. The Spartans were, to Herodotus, Hellenic ; the Athenians on the other hand were not. They were Pelasgian, but by a certain time 'changed into Hellenes and learnt the language'. In historical times we cannot really find any tribe of pure Hellenes in existence, though the name clings faintly to a particular district, not otherwise important, in South Thessaly. Had there been any undoubted Hellenes with incontrovertible pedigrees still going, very likely the ideal would have taken quite a different name. But where no one's ancestry would bear much inspection, the only way to show you were a true Hellene was to behave as such: that is, to approximate to some constantly rising ideal of what the true Hellene

1 Hdt. i. 56 f.; Th. i. 3 (Hellen son of Deucalion, in both). 
should be. In all probability if a Greek of the fifth century, like Aeschylus or even Pindar, had met a group of the real Hellenes or Achaioi of the Migrations, he would have set them down as so many obvious and flaming barbarians.

We do not know whether the old Hellenes had any general word to denote the surrounding peoples ('Pelasgians and divers other barbarous tribes' 1 ) whom they conquered or accepted as allies. ${ }^{2}$ In any case by the time of the Persian Wars (say 500 в. c.) all these tribes together considered themselves Hellenized, bore the name of 'Hellenes', and formed a kind of unity against hordes of 'barbaroi' surrounding them on every side and threatening them especially from the east.

Let us consider for a moment the dates. In political history this self-realization of the Greek tribes as Hellenes against barbarians seems to have been first felt in the Ionian settlements on the coast of Asia Minor, where the 'sons of Javan' (Yawan='Ia' $\omega \nu$ ) clashed as invaders against the native Hittite and Semite. It was emphasized by a similar clash in the further colonies in Pontus and in the West. If we wish for a central moment as representing this selfrealization of Greece, I should be inclined to find it in the reign of Pisistratus (560-527 в.c.) when that

${ }^{1}$ Hdt. i. 58. In viii. 44 the account is more detailed.

2 The Homeric evidence is, as usual, inconclusive. The word Bápßapor is absent from both poems, an absence which must be intentional on the part of the later reciters, but may well come

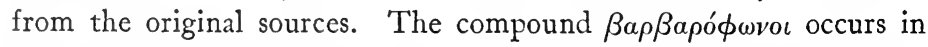
13 867, but who knows the date of that particular line in that particular wording? 
monarch made, as it were, the first sketch of an Athenian empire based on alliances and took over to Athens the leadership of the Ionian race.

In literature the decisive moment is clear. It came when, in Mr. Mackail's phrase, 'Homer came to Hellas.' 1 The date is apparently the same, and the influences at work are the same. It seems to have been under Pisistratus that the Homeric Poems, in some form or other, came from Ionia to be recited in a fixed order at the Panathenaic Festival, and to find a canonical form and a central home in Athens till the end of the classical period. Athens is the centre from which Homeric influence radiates over the mainland of Greece. Its effect upon literature was of course enormous. It can be traced in various ways. By the content of the literature, which now begins to be filled with the heroic saga. By a change of style which emerges in, say, Pindar and Aeschylus when compared with what we know of Corinna or Thespis. More objectively and definitely it can be traced in a remarkable change of dialect. 'The old Attic poets, like Solon, were comparatively little affected by the epic influence; the later elegists, like Ion, Euenus, and Plato, were steeped in it. ${ }^{2}$

1 Paper read to the Classical Association at Birmingham in 1908.

2 For Korinna see Wilamowitz in Berliner Klassikertexte, V. xiv, especially p. 55. The Homeric epos drove out poetry like Corinna's. She had actually written: 'I sing the great deeds of heroes and

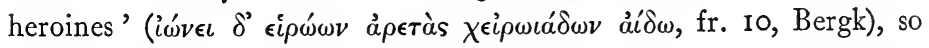
that presumably her style was sufficiently 'heroic' for an un-Homeric generation. For the change of dialect in elegy, \&c., see Thumb, Handbucb d. gr. Dialekte, pp. 327-30, $368 \mathrm{ff}$., and the literature there 
In religion the cardinal moment is the same. It consists in the coming of Homer's 'Olympian Gods', and that is to be the subject of the present essay. I am not, of course, going to describe the cults and characters of the various Olympians. For that inquiry the reader will naturally go to the five learned volumes of my colleague, Dr. Farnell. I wish merely to face certain difficult and, I think, hitherto unsolved problems affecting the meaning and origin and history of the Olympians as a whole.

Herodotus in a famous passage tells us that Homer and Hesiod 'made the generations of the Gods for the Greeks and gave them their names and distinguished their offices and crafts and portrayed their shapes' (2. 53). 'The date of this wholesale proceeding was, he thinks, perhaps as much as four hundred years before his own day (c. 430 B.c.) but not more. Before that time the Pelasgians-i.e. the primitive inhabitants of Greece as opposed to the Helleneswere worshipping gods in indefinite numbers, with no particular names; many of them appear as figures carved emblematically with sex-emblems to represent the powers of fertility and generation, like the Athenian 'Herms'. 'The whole account bristles with points for discussion, but in general it suits very well with the picture drawn in the first of these essays, with its Earth Maidens and Mothers and its projected Kouroi. 'The background is the pre-Hellenic 'Urdummheit';

cited. Fick and Hoffmann overstated the change, but Hoffmann's new statement in Die griecbische Sprache, 191 I, sections on Die Elegie, seems just. The question of Tyrtaeus is complicated by other problems. 
the new shape impressed upon it is the great anthropomorphic Olympian family, as defined in the Homeric epos and, more timidly, in Hesiod. But of Hesiod we must speak later.

Now who are these Olympian Gods and where do they come from? Homer did not 'make' them out of nothing. But the understanding of them is beset with problems.

In the first place why are they called 'Olympian'? Are they the Gods of Mount Olympus, the old sacred mountain of Homer's Achaioi, or do they belong to the great sanctuary of Olympia in which Zeus, the lord of the Olympians, had his greatest festival? The two are at opposite ends of Greece, Olympus in North Thessaly in the north-east, Olympia in Elis in the south-west. From which do the Olympians come? On the one hand it is clear in Homer that they dwell on Mount Olympus; they have 'Olympian houses' beyond human sight, on the top of the sacred mountain, which in the Odyssey is identified with heaven. On the other hand, when Pisistratus introduced the worship of Olympian Zeus on a great scale into Athens and built the Olympieum, he seems to have brought him straight from Olympia in Elis. For he introduced the special Elean complex of gods, Zeus, Rhea, Kronos, and Gê Olympia. ${ }^{1}$

Fortunately this puzzle can be solved. The Olympians belong to both places. It is merely a case of

1 The facts are well known: see Paus. i. 18. 7. The inference was pointed out to me by Miss Harrison. 
tribal migration. History, confirmed by the study of the Greek dialects, seems to show that these northern Achaioi came down from Thessaly across central Greece and the Gulf of Corinth and settled in Elis. ${ }^{1}$ They brought with them their Olympian Zeus and established him as superior to the existing god, Kronos. The Games became Olympian and the sanctuary by which they were performed 'Olympia '.2

As soon as this point is ciear, we understand also why there is more than one Mount Olympus. We can all think of two, one in Thessaly and one across the Aegean in Mysia. But there are many more; some twentyodd, if I mistake not, in the whole Greek region. Whatever the original meaning of 'Olympus' may be, it seems clear that the Olympian gods, wherever their worshippers moved, tended to dwell in the highest mountain in the neighbourhood, and the mountain thereby became Olympus.

The name, then, explains itself. The Olympians are the mountain gods of the old invading Northmen, the chieftains and princes, each with his comitatus or loose following of retainers and minor chieftains, who broke in upon the ordered splendours of the Aegean palaces and, still more important, on the ordered simplicity of tribal life in the pre-Hellenic villages of the

${ }^{1}$ I do not here raise the question how far the Achaioi have special affinities with the north-west group of tribes or dialects. See Thumb, Handbuch d. gr. Dialekte (1909), p. I66 f. The Achaioi must have passed through South Thessaly in any case.

2 That Kronos was in possession of the Kronion and Olympia generally before Zeus came was recognized in antiquity; Paus. v. 7.4 and 1o. Also Mayer in Roscher's Lexicon, ii, p. 1508, $50 \mathrm{ff}$. 
mainland. Now, it is a canon of religious study that all gods reflect the social state, past or present, of their worshippers. From this point of view what appearance do the Olympians of Homer make? What are they there for? What do they do, and what are their relations one to another?

The gods of most nations claim to have created the world. The Olympians make no such claim. The most they ever did was to conquer it. Zeus and his comitatus conquered Cronos and his; conquered and expelled them-sent them migrating beyond the horizon, Heaven knows where. Zeus took the chief dominion and remained a permanent overlord, but he apportioned large kingdoms to his brothers Hades and Poseidon, and confirmed various of his children and followers in lesser fiefs. Apollo went off on his own adventure and conquered Delphi. Athena conquered the Giants. She gained Athens by a conquest over Poseidon, a point of which we will speak later.

And when they have conquered their kingdoms, what do they do? Do they attend to the government? Do they promote agriculture? Do they practise trades and industries? Not a bit of it. Why should they do any honest work? They find it easier to live on the revenues and blast with thunderbolts the people who do not pay. They are conquering chieftains, royal buccaneers. They fight, and feast, and play, and make music; they drink deep, and roar with laughter at the lame smith who waits on them. They are never afraid, except of their own king. They never tell lies, except in love and war. 
A few deductions may be made from this statement, but they do not affect its main significance. One god, you may say, Hephaistos, is definitely a craftsman. Yes : a smith, a maker of weapons. The one craftsman that a gang of warriors needed to have by them; and they preferred him lame, so that he should not run away. Again, Apollo herded for hire the cattle of Admetus; Apollo and Poseidon built the walls of Troy for Laomedon. Certainly in such stories we have an intrusion of other elements; but in any case the work done is not habitual work, it is a special punishment. Again, it is not denied that the Olympians have some effect on agriculture and on justice: they destroy the harvests of those who offend them, they punish oath-breakers and the like. Even in the Heroic Age itself-if we may adopt Mr. Chadwick's convenient title for the Age of the Migrations-chieftains and gods probably retained some vestiges of the functions they had exercised in more normal and settled times; and besides we must always realize that, in these inquiries, we never meet a simple and uniform figure. We must further remember that these gods are not real people with a real character. They never existed. They are only concepts, exceedingly confused cloudy and changing concepts, in the minds of thousands of diverse worshippers and non-worshippers. They change every time they are thought of, as a word changes every time it is pronounced. Even in the height of the Achaean wars the concept of any one god would be mixed up with traditions and associations drawn from the surrounding populations and 
their gods; and by the time they come down to us in Homer and our other early literature, they have passed through the minds of many different ages and places, especially Ionia and Athens.

The Olympians described in our text of Homer, or as described in the Athenian recitations of the sixth century, are mutatis mutandis related to the Olympians of the Heroic Age much as the Hellenes of the sixth century are to the Hellenes of the Heroic Age. I say ' mutatis mutandis', because the historical development of a group of imaginary concepts shrined in tradition and romance can never be quite the same as that of the people who conceive them. The realm of fiction is apt both to leap in front and to lag in the rear of the march of real life. Romance will hug picturesque darknesses as well as invent perfections. But the gods of Homer, as we have them, certainly seem to show traces of the process through which they have passed: of an origin among the old conquering Achaioi, a development in the Ionian epic schools, and a final home in Athens. ${ }^{1}$

1 I do not touch here on the subject of the gradual expurgation of the Poems to suit the feelings of a more civilized audience; see Rise of the Greek Epic, ${ }^{2}$ pp. I4 I-67. Many scholars believe that the Poems did not exist as a written book till the public copy was made by Pisistratus; see Cauer, Grundfragen der Homerkritik 2 (I909), pp. I I345; R.G.E., p. 320 ; Leaf, Iliad, vol. i, p. xvi. This view is tempting, though the evidence seems to be insufficient to justify a pronouncement either way. If it is true, then various passages which show a verbal use of earlier documents (like the Bellerophon passage, R.G.E., p. I97-9) cannot have been put in before the Athenian period. 
For example, what gods are chiefly prominent in Homer? In the Iliad certainly three, Zeus, Apollo, and Athena, and much the same would hold for the Odyssey. Next to them in importance will be Poseidon, Hera, and Hermes.

Zeus stands somewhat apart. He is one of the very few gods with recognizable and undoubted Indogermanic names, Djeus, the well-attested sky- and rain-god of the Aryan race. $\mathrm{He}$ is Achaian; he is 'Hellanios', the god worshipped by all Hellenes. He is also, curiously enough, Pelasgian, and Mr. A. B. Cook ${ }^{1}$ can explain to us the seeming contradiction. But the Northern elements in the conception of Zeus have on the whole triumphed over any Pelasgian or Aegean skygod with which they may have mingled, and Zeus, in spite of his dark hair, may be mainly treated as the patriarchal god of the invading Northmen, passing from the Upper Danube down by his three great sanctuaries, Dodona, Olympus, and Olympia. He had an extraordinary power of ousting or absorbing the various objects of aboriginal worship which he found in his path. The story of Meilichios above (p. 28) is a common one. Of course, we must not suppose that the Zeus of the actual Achaioi was a figure quite like the Zeus of Pheidias or of Homer. There has been a good deal of expurgation in the Homeric Zeus, ${ }^{2}$ as Mr. Cook clearly shows. The Counsellor and Cloudcompeller of classical Athens was the wizard and rain-

${ }^{1}$ In his forthcoming work, Zeus, the Indo-European Sky-God.

2 A somewhat similar change occurred in Othin, though he always retains more of the crooked wizard. 
maker of earlier times; and the All-Father surprises us in Thera and Crete by appearing both as a babe and as a Kouros in spring dances and initiation rituals. ${ }^{1}$ It is a long way from these conceptions to the Zeus of Aeschylus, a figure as sublime as the Jehovah of Job; but the lineage seems clear.

Zeus is the Achaean Sky-god. His son Phoebus Apollo is of more complex make. On one side he is clearly a Northman. He has connexions with the Hyperboreans. $^{2}$ He has a 'sacred road' leading far into the North, along which offerings are sent back from shrine to shrine beyond the bounds of Greek knowledge. Such 'sacred roads' are normally the roads by which the God himself has travelled; the offerings are sent back from the new sanctuary to the old. On the other side Apollo reaches back to an Aegean matriarchal Kouros. His home is Delos, where he has a mother, Leto, but no very visible father. $\mathrm{He}$ leads the ships of his islanders, sometimes in the form of a dolphin. He is no 'Hellene'. In the fighting at Troy he is against the Achaioi: he destroys the Greek host, he champions Hector, he even slays Achilles. In the Homeric hymn to Apollo we read that when the great archer draws near to Olympus all the gods tremble and start from their seats; Leto alone, and of course Zeus, hold their ground. ${ }^{3}$ What

1 Themis, chap. i. On the Zeus of Aeschylus cf. R.G.E., pp. 29I-5; Gomperz, Greek Thinkers, ii. 6-8.

${ }^{2}$ Farnell, Cults, iv. Ioo-4. See, however, Gruppe, p. Io7 f.

3 Hymn. Ap. init. Cf. Wilamowitz's Oxford Lecture on 'Apollo' (Oxford, 1907). 
this god's original name was at Delos we cannot be sure: he has very many names and 'epithets'. But he early became identified with a similar god at Delphi and adopted his name, 'Apollôn,' or, in the Delphic and Dorian form, 'Apellôn'-evidently the Kouros projected from the Dorian gatherings called 'apellae'.' As Phoibos he is a sun-god, and from classical times onward we often find him definitely identified with the Sun, a distinction which came easily to a Kouros.

In any case, and this is the important point, he is at Delos the chief god of the Ionians. The Ionians are defined by Herodotus as those tribes and cities who were sprung from Athens and kept the Apaturia. They recognized Delos as their holy place and worshipped Apollo Patrôos as their ancestor. ${ }^{2}$ The Ionian Homer has naturally brought us the Ionian god; and, significantly enough, though the tradition makes him an enemy of the Greeks, and the poets have to accept the tradition, there is no tendency to crab or belittle him. He is the most splendid and awful of Homer's Olympians.

The case of Pallas Athena is even simpler, though it leads to a somewhat surprising result. What Apollo is to Ionia that, and more, Athena is to Athens. There are doubtless foreign elements in Athena, some Cretan

1 Themis, p. 439 f. Other explanations of the name in Gruppe, p. I224 f., notes.

${ }^{2}$ Hdt. i. I47; Plato, Eutbyd. $302 \mathrm{c}$ : Socrates. 'No Ionian recognizes a Zeus Patrôos; Apollo is our Patrôos, because he was father of Ion.' 
and Ionian, some Northern. ${ }^{1}$ But her whole appearance in history and literature tells the same story as her name. Athens is her city and she is the goddess of Athens, the Athena or Athenaia Korê. In Athens she can be simply 'Parthenos', the Maiden; elsewhere she is the 'Attic' or 'Athenian Maiden'. As Glaucopis she is identified or associated with the Owl that was the sacred bird of Athens. As Pallas she seems to be a Thunder-maiden, a sort of Keraunia or bride of Keraunos. A Palladion consists of two thunder-shields, set one above the other like a figure 8 , and we can trace in art-types the development of this 8 into a human figure. It seems clear that the old Achaioi cannot have called their warrior-maiden, daughter of Zeus, by the name Athena or Athenaia. The Athenian goddess must have come in from Athenian influence, and it is strange to find how deep into the heart of the poems that influence must have reached. If we try to conjecture whose place it is that Athena has taken, it is worth remarking that her regular epithet, ' daughter of Zeus,' belongs in Sanskrit to the Dawn-goddess, Eôs. ${ }^{2}$ The transition might be helped by some touches of the Dawn-goddess that seem to linger about Athena in myth. The rising Sun stayed his horses while Athena was born from the head of Zeus. Also she was born amid a snow-storm of gold. And Eôs, on the other hand, is,

1 See Gruppe, p. I206, on the development of his 'Philistine thunderstorm-goddess'.

${ }^{2}$ Hoffmann, Gesch. d. griechischen Sprache, Leipzig, I9I I, p. I6. Cf. Pind. Ol. vii. 35 ; Ov. Metam. ix. 421 ; xv. 19I, 700, \&c. 
like Athena, sometimes the daughter of the Giant Pallas. ${ }^{1}$

Our three chief Olympians, then, explain themselves very easily. A body of poetry and tradition, in its origin dating from the Achaioi of the Migrations, growing for centuries in the hands of Ionian bards, and reaching its culminating form at Athens, has prominent in it the Achaian Zeus, the Ionian Apollo, the Athenian Korê-the same Korê who descended

1 As to the name, 'A $\theta$ qvaía is of course simply 'Athenian'; the shorter and apparently original form 'A $\theta \dot{\alpha} v a, \mathrm{~A} \theta \dot{\eta} \nu \eta$ is not so clear, but it seems most likely to mean 'Attic'. Cf. Meister, Gr. Dial. ii. 290. He classes under the head of Oertliche Bestimmungen : a $\theta$ єòs $a$ Ma (Collitz and Bechtel, Sammlung der griechischen Dialekt-Inschriften, 2, 3, 14 a , b, 15, 16). 'In Paphos selbst hiess die Göttin nur a $\theta$ cós

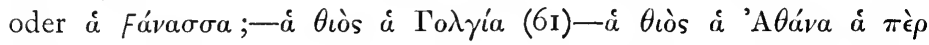

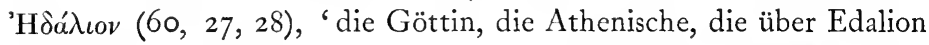
(waltet) '; "A $\theta$-áva ist, wie J. Baunack (Studia Nicolaitana, s. 27) gezeigt hat, das Adjectiv zu (*'A $\sigma \sigma$-ís' 'Seeland ') : 'A $\tau \tau$-ís; 'A $\tau \theta$-ís; *'A $\mathrm{A}$-ís; also 'A $\theta-a ́ v a=$ 'A $\mathrm{\tau} \tau-\iota \kappa \hat{\eta}$, 'A $\mathrm{A}-\hat{\eta} v a \iota$ ursprünglich 'A $\theta-\hat{\eta} v a \iota$ $\kappa \hat{\omega} \mu a \iota$. ' Other derivations in Gruppe, p. II94. Or again ai 'A $\theta \hat{\eta} v a \iota$ may be simply ' the place where the Athenas are', like oi ' $\chi \theta \theta$ ' $\epsilon$, the fish-market; 'the Athenas' would be statues, like oi 'Eppaî-the famous 'Attic Maidens' on the Acropolis. This explanation would lead to some interesting results.

We need not here consider how, partly by identification with other Korae, like Pallas, Onka, \&c., partly by a genuine spread of the cult, Athena became prominent in other cities. As to Homer, Athena is far more deeply imbedded in the Odyssey than in the Iliad. I am inclined to agree with those who believe that our Odyssey was very largely composed in Athens, so that in most of the poem Athena is original. (Cf. O. Seeck, Die Quellen der Odyssee (1887), pp. 366-420; Mülder, Die Ilias und ibre Quellen (1910), pp. 350-5.) In some parts of the Iliad the name Athena may well have been substituted for some Northern goddess whose name is now lost. 
in person to restore the exiled Pisistratus to his throne. ${ }^{1}$

We need only throw a glance in passing at a few of the other Olympians. Why, for instance, should Poseidon be so prominent? In origin he is a puzzling figure. Besides the Achaean Earth-shaking brother of Zeus in Thessaly there seems to be some Pelasgian or Aegean god present in him. He is closely connected with Libya; he brings the horse from there. ${ }^{2}$ At times he exists in order to be defeated; defeated in Athens by Athena, in Naxos by Dionysus, in Aegina by Zeus, in Argos by Hera, in Acrocorinth by Helios though he continues to hold the Isthmus. In Trozen he shares a temple on more or less equal terms with Athena. ${ }^{3}$ Even in Troy he is defeated and cast out from the walls his own hands had built. ${ }^{4}$ These problems we need not for the present face. By the time that concerns us most the Earth-Shaker is a seagod, specially important to the sea-peoples of Athens

1 It is worth noting also that this Homeric triad seems also to be recognized as the chief Athenian triad. Plato, Eutbyd. 302 c, quoted above, continues: Socrates. "We have Zeus with the names Herkeios and Phratrios, but not Patrôos, and Athena Phratria.' Dionysodorus. 'Well, that is enough. You have, apparently, Apollo and Zeus and Athena?' Socrates. 'Certainly.'-Apollo is put first because he has been accepted as Patrôos.

2 Ridgeway, Origin and Infuence of the Thorougbbred Horse, 1905, pp. 287-93; and Early Age of Greece, I90I, p. 223.

3 Cf. Plut. Q. Conv. ix. 6; Paus. ii. 1. 6; 4. 6; 15. 5 ; 30.6.

4 So in the non-Homeric tradition, Eur. Troades init. In the Iliad he is made an enemy of Troy, like Athena, who is none the less the Guardian of the city. 
and Ionia. $\mathrm{He}$ is the father of Neleus, the ancestor of the Ionian kings. His temple at Cape Mykale is the scene of the Panionia, and second only to Delos as a religious centre of the Ionian tribes. He has intimate relations with Attica too. Besides the ancient contest with Athena for the possession of the land, he appears as the father of 'Theseus, the chief Athenian hero. $\mathrm{He}$ is merged in other Attic heroes, like Aigeus and Erechtheus. He is the special patron of the Athenian knights. Thus his prominence in Homer is very natural.

What of Hermes? His history deserves a long monograph to itself; it is so exceptionally instructive. Originally, outside Homer, Hermes was simply an old upright stone, a pillar furnished with the regular Pelasgian sex-symbol of procreation. Set up over a tomb he is the power that generates new lives, or, in the ancient conception, brings the souls back to be born again. He is the Guide of the Dead, the Psychopompos, the divine Herald between the two worlds. If you have a message for the dead, you speak it to the Herm at the grave. This notion of Hermes as herald may have been helped by his use as a boundarystone-the Latin Terminus. Your boundary-stone is your representative, the deliverer of your message, to the hostile neighbour or alien. If you wish to parley with him, you advance up to your boundary-stone. If you go, as a Herald, peacefully, into his territory, you place yourself under the protection of the same sacred stone, the last sign that remains of your own safe country. If you are killed or wronged, it is he, the immovable Watcher, who will avenge you. 
Now this phallic stone post was quite unsuitable to Homer. It was not decent; it was not quite human; and every personage in Homer has to be both. In the Iliad Hermes is simply removed, and a beautiful creation or tradition, Iris, the rainbow-goddess, takes his place as the messenger from heaven to earth. In the Odyssey he is admitted, but so changed and castigated that no one would recognize the old Herm in the beautiful and gracious youth who performs the gods' messages. I can only detect in his language one possible trace of his old Pelasgian character. ${ }^{1}$

Pausanias knew who worked the transformation. In speaking of Hermes among the other 'Workers', who were ' pillars in square form', he says, 'As to Hermes, the poems of Homer have given currency to the report that he is a servant of $Z$ eus and leads down the spirits of the departed to Hades.' 2 In the magic papyri Hermes returns to something of his old functions; he is scarcely to be distinguished from the Agathos Daimon. But thanks to Homer he is purified of his old fhallicism.

Hera, too, the wife of Zeus, seems to have a curious past behind her. She has certainly ousted the original wife, Dione, whose worship continued unchallenged in far Dodona, from times before Zeus descended upon Greek lands. When he invaded Thessaly he seems to have left Dione behind and wedded the Queen of the conquered territory. Hera's permanent epithet is 'Argeia ', 'Argive.' She is the Argive Korê, or Year-

1 Od. H 339 ff.

2 See Paus. viii. 32. 4. Themis, pp. 295, 296. 
Maiden, as Athena is the Attic, Cypris the Cyprian. But Argos in Homer denotes two different places, a watered plain in the Peloponnese and a watered plain in Thessaly. Hera was certainly the chief goddess of Peloponnesian Argos in historic times, and had brought her consort Herakles ${ }^{1}$ along with her, but originally she seems to have belonged to the Thessalian Argos. She helped Thessalian Jason to launch the ship Argo, and they launched it from Thessalian Pagasae. In the Argonautica she is a beautiful figure, gracious and strong, the lovely patroness of the young hero. No element of strife is haunting her. But in the Iliad for some reason she is unpopular. She is a shrew, a scold, and a jealous wife. Why? Miss Harrison suggests that the quarrel with Zeus dates from the time of the invasion, when he was the conquering alien and she the native queen of the land. ${ }^{2}$ It may be, too, that the Ionian poets who respected their own Apollo and Athena and Poseidon, regarded Hera as representing some race or tribe that they disliked. A goddess of Dorian Argos might be as disagreeable as a Dorian. It seems to be for some reason like this that Aphrodite, identified with Cyprus or some centre among Oriental

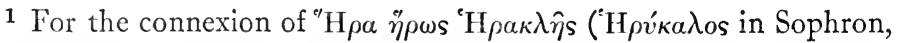
fr. I 42 K) see especially A. B. Cook, Class. Review, 1906, pp. 365 and 416. The name "H $\rho \alpha$ seems probably to be an ablaut form of $\varkappa_{\rho} \alpha$ : cf. phrases like "Hpa $\tau \in \lambda \epsilon i a$. Other literature in Gruppe, pp. 452, I I 22 .

2 Prolegomena, p. 315, referring to H. D. Müller, Mythologie $d$. gr. Stämme, pp. 249-55. Another view is suggested by Mülder, Die Ilias und ibre Quellen, p. 136 . The jealous Hera comes from the Heracles-saga, in which the wife hated the bastard. 
barbarians, is handled with so much disrespect; that Ares, the Thracian Kouros, a Sun-god and War-god, is treated as a mere bully and coward and general pest. ${ }^{1}$

There is not much faith in these gods, as they appear to us in the Homeric Poems, and not much respect, except perhaps for Apollo and Athena and Poseidon. The buccaneer kings of the Heroic Age, cut loose from all local and tribal pieties, intent only on personal gain and glory, were not the people to build up a powerful religious faith. They left that, as they left agriculture and handiwork, to the nameless common folk. ${ }^{2}$ And it was not likely that the bards of cultivated and scientific Ionia should waste much religious emotion on a system which was clearly meant more for romance than for the guiding of life.

Yet the power of romance is great. In the memory of Greece the kings and gods of the Heroic Age were transfigured. What had been really an age of reckless brutality became in memory an age of chivalry and splendid adventure. The traits that were at all tolerable were idealized; those that were intolerable were either expurgated, or, if that was impossible, were mysticized and explained away. And the savage old Olympians became to Athens and the mainland of Greece from the sixth century onward emblems of high humanity and religious reform.

1 P.Gardner, in Numismatic Cbronicle, N.S. xx, 'Ares as a Sun-God.'

${ }^{2}$ Chadwick, Heroic Age, especially pp. 4I4, 459-63. 


\section{The Religious Value of the Olympians}

Now to some people this statement may seem a wilful paradox, yet I believe it to be true. The Olympian religion, radiating from Homer at the Panathenaea, produced what I will venture to call exactly a religious reformation. Let us consider how, with all its flaws and falsehoods, it was fitted to attempt such a work.

In the first place the Poems represent an Achaian tradition, the tradition of a Northern conquering race, organized on a patriarchal monogamous system vehemently distinct from the matrilinear customs of the Aegean or Hittite races, with their polygamy and polyandry, their agricultural rites, their sex-emblems and fertility goddesses. Contrast for a moment the sort of sexless Valkyrie who appears in the Iliad under the name of Athena with the Korê of Ephesus, strangely called Artemis, a shapeless fertility figure, covered with innumerable breasts. That suggests the contrast that I mean.

Secondly, the poems are by tradition aristocratic; they are the literature of chieftains, alien to low popular superstition. True, the poems as we have them are not Court poems. That error ought not to be so often repeated. As we have them they are poems recited at a Panegyris, or public festival. But they go back in ultimate origin to something like lays sung in a royal hall. And the contrast between the Homeric gods and the gods found outside Homer is well compared by Mr. Chadwick ${ }^{1}$ to the difference

1 Chap. xviii. 
between the gods of the Edda and the historical traces of religion outside the Edda. The gods who feast with Odin in Asgard, forming an organized community or comitatus, seem to be the gods of the kings, distinct from the gods of the peasants, cleaner and more warlike and lordlier, though in actual religious quality much less vital.

Thirdly, the poems in their main stages are Ionian, and Ionia was for many reasons calculated to lead the forward movement against the Urdummheit. For one thing, Ionia reinforced the old Heroic tradition, in having much the same inward freedom. The Ionians are the descendants of those who fled from the invaders across the sea, leaving their homes, tribes, and tribal traditions. Wilamowitz has well remarked how the imagination of the Greek mainland is dominated by the gigantic sepulchres of unknown kings, which the fugitives to Asia had left behind them and half forgotten. ${ }^{1}$

Again, when the Ionians settled on the Asiatic coasts they were no doubt to some extent influenced, but they were far more repelled by the barbaric tribes of the interior. They became conscious, as we have said, of something that was Hellenic, as distinct from something else that was barbaric, and the Hellenic part of them vehemently rejected what struck them as superstitious, cruel, or unclean. And lastly, we must remember that Ionia was, before the rise of Athens, not only the most imaginative and intellectual part of Greece, but by far the most advanced in knowledge

1 Introduction to his edition of the Choephori, p. 9. 
and culture. The Homeric religion is a step in the self-realization of Greece, and such self-realization naturally took its rise in Ionia.

Granted, then, that Homer was calculated to produce a kind of religious reformation in Greece, what kind of reformation was it? We are again reminded of St. Paul. It was a move away from the 'beggarly elements' towards some imagined person behind them. The world was conceived as neither quite without external governance, nor as merely subject to the incursions of mana snakes and bulls and thunder-stones and monsters, but as governed by an organized body of personaland reasoning rulers, wise and bountiful fathers, like man in mind and shape, only unspeakably higher.

For a type of this Olympian spirit we may take a phenomenon that has perhaps sometimes wearied us : the reiterated insistence in the reliefs of the best period on the strife of men against centaurs or of gods against giants. Our modern sympathies are apt to side with the giants and centaurs. An age of order likes romantic violence, as landsmen safe in their houses like storms at sea. But to the Greek, this battle was full of symbolical meaning. It is the strife, the ultimate victory, of human intelligence, reason, and gentleness, against what seems at first the overwhelming power of passion and unguided strength. It is Hellas against the brute world. ${ }^{1}$

1 The spirit appears very simply in Eur. Iph. Taur. 386 ff., where Iphigenia rejects the gods who demand human sacrifice:

These tales be false, false as those feastings wild Of Tantalus, and gods that tare a child. 
The victory of Hellenism over barbarism, of man over beast : that was the aim, but was it ever accomplished? The Olympian gods as we see them in art appear so calm, so perfect, so far removed from the atmosphere of acknowledged imperfection and spiritual striving, that what I am now about to say may again seem a deliberate paradox. It is nevertheless true that the Olympian Religion is only to the full intelligible and admirable if we realize it as a superb and baffled endeavour, not a telos or completion but a movement and effort of life.

We may analyse the movement into three main elements : a moral expurgation of the old rites, an attempt to bring order into the old chaos, and lastly an adaptation to new social needs. We will take the three in order.

In the first place, it gradually swept out of religion, or at least covered with a decent veil, that great mass of rites which was concerned with the Food-supply and the Tribe-supply and aimed at direct stimulation

\section{This land of murderers to its gods hath given}

Its own lust. Evil dwelleth not in heaven.

Yet just before she has accepted the loves of Zeus and Leto without objection. 'Leto, whom $Z$ eus loved, could never have given birth to uch a monster!' Cf. Plutarch, Vit. Pelop. xxi, where Pelopidas, in :ejecting the idea of a human sacrifice, says: "No high and more than human beings could be pleased with so barbarous and unlawful sacrifice. It was not the fabled Titans and Giants who ruled the world, but one who was a Father of all gods and men.' Of course, criticism and expurgation of the legends is too common to need illustration. See especially Kaibel, Daktyloi Idanoi, I902, p. $5 \mathrm{I} 2$. 
of generative processes. ${ }^{1}$ It left only a few reverent and mystic rituals, a few licensed outbursts of riotous indecency in comedy, and the agricultural festivals. It swept away what seems to us a thing less dangerous, a large part of the worship of the dead. Such worship, our evidence shows us, gave a loose rein to superstition. To the Olympian movement it was vulgar, it was semibarbarous, it was often bloody. We find that it has almost disappeared from Homeric Athens at a time when the monuments show it still flourishing in unHomeric Sparta. The Olympian movement swept away also, at least for two splendid centuries, the worship of the man-god, with its diseased atmosphere of megalomania and blood-lust. ${ }^{2}$ These things return with the fall of Hellenism; but the great period, as it urges man to use all his powers of thought, of daring and endurance, of social organization, so it bids him remember that he is a man like other men, subject to the same laws and bound to reckon with the same death.

So much for the moral expurgation : next for the bringing of intellectual order. To parody the words of Anaxagoras, 'In the early religion all things were together, till the Homeric system came and arranged them.'

We constantly find in the Greek pantheon beings

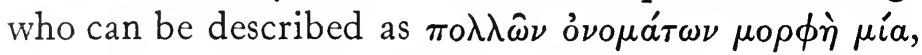
' one form of many names.' Each tribe, each little community, sometimes one may almost say each caste

1 I have touched on this subject in an article, 'Olympian Houses,' in the Albany Review, 1907, p. 201.

2 R. G. E., pp. 158-6r. 
-the Children of the Bards, the Children of the Potters-had its own special gods. Now as soon as there was any general 'Sunoikismos' or 'Settlingtogether', any effective surmounting of the narrowest local barriers, these innumerable gods tended to melt into one another. Under different historical circumstances this process might have been carried resolutely through and produced an intelligible pantheon in which each god had his proper function and there was no overlapping-one Korê, one Kouros, one Sun-God, and so on. But in Greece that was impossible. Imaginations had been too vivid, and local types had too often become clearly personified and differentiated. The Maiden of Athens, Athena, did no doubt absorb some other Korai, but she could not possibly combine with her of Cythêra or Cyprus, or Ephesus, nor with the Argive Korê or the Delian or the Brauronian. What happened was that the infinite cloud of Maidens was greatly reduced and fell into four or five main types. The Korai of Cyprus, Cythêra, Corinth, Eryx, and some other places were felt to be one, and became absorbed in the great figure of Aphrodite. Artemis absorbed a quantity more, including those of Delos and Brauron, of various parts of Arcadia and Sparta, and even, as we saw, the fertility Korê of Ephesus. Doubtless she and the Delian were originally much closer together, but the Delian differentiated towards ideal virginity, the Ephesian towards ideal fruitfulness. The Kouroi, or Youths, in the same way were absorbed into some half-dozen great mythological shapes, Apollo, Ares, Hermes, Dionysus, and the like. 
As so often in Greek development, we are brought up against the immense formative power of fiction or romance. The simple Korê or Kouros was a figure of indistinct outline with no history or personality. Like the Roman functional gods, such beings were hardly persons; they melted easily one into another. But when the Greek imagination had once done its work upon them, a figure like Athena or Aphrodite had become, for all practical purposes, a definite person, almost as definite as Achilles or Odysseus, as Macbeth or Falstaff. 'They crystallize hard. They will no longer melt or blend, at least not at an ordinary temperature. In the fourth and third centuries we hear a great deal about the gods all being one, 'Zeus the same as Hades, Hades as Helios, Helios the same as Dionysus,' ${ }^{1}$ but the amalgamation only takes place in the white heat of ecstatic philosophy or the rites of religious mysticism.

The best document preserved to us of this attempt to bring order into Chaos is the poetry of Hesiod. There are three poems, all devoted to this object, composed perhaps under the influence of Delphi and certainly under that of Homer, and trying in a quasiHomeric dialect and under a quasi-Olympian system to bring together vast masses of ancient theology and folk-lore and scattered tradition. The $T$ beogony attempts to make a pedigree and hierarchy of the Gods; The Catalogue of Women and the Eoiai,

1 Justin. Cobort. c. 15. But such pantheistic language is common in Orphic and other mystic literature. See the fragments of the Orphic $\Delta_{\iota} a \hat{\eta} \kappa a \iota$ (p. I44.ff. in Abel's Hymni). 
preserved only in scanty fragments, attempt to fix in canonical form the cloudy mixture of dreams and boasts and legends and hypotheses by which most royal families in central Greece recorded their descent from a traditional ancestress and a conjectural God. The $W$ orks and Days form an attempt to collect and arrange the rules and tabus relating to agriculture. The work of Hesiod as a whole is one of the most valiant failures in literature. The confusion and absurdity of it are only equalled by its strange helpless beauty and its extraordinary historical interest. The Hesiodic system when compared with that of Homer is much more explicit, much less expurgated, infinitely less accomplished and tactful. At the back of Homer lay the lordly warrior-gods of the Heroic Age, at the back of Hesiod the crude and tangled superstitions of the peasantry of the mainland. Also the Hesiodic poets worked in a comparatively backward and unenlightened atmosphere, the Homeric were exposed to the full light of Athens.

The third element in this Homeric reformation is an attempt to make religion satisfy the needs of a new social order. The earliest Greek religion was clearly based on the tribe, a band of people, all in some sense kindred and normally living together, people with the same customs, ancestors, initiations, flocks and herds and fields. This tribal and agricultural religion can hardly have maintained itself unchanged at the great Aegean centres, like Cnossus and Mycenae. ${ }^{1}$ It

${ }^{1}$ I have not attempted to consider the Cretan cults. They lie historically outside the range of these essays, and I am not competent 
certainly did not maintain itself among the marauding chiefs of the heroic age. It bowed its head beneath the sceptre of its own divine kings and the armed heel of its northern invaders, only to appear again almost undamaged and unimproved when the kings were fallen and the invaders sunk into the soil like storms of destructive rain.

But it no longer suited its environment. In the age of the migrations the tribes had been broken, scattered, re-mixed. They had almost ceased to exist as important social entities. The social unit which had taken their place was the political community of men, of whatever tribe or tribes, who were held together in times of danger and constant war by means of a common circuit-wall, a Polis. ${ }^{1}$ 'The idea of the tribe remained. In the earliest classical period we find every Greek city still nominally composed of tribes, but the tribes are fictitious. The early citymakers could still only conceive of society on a tribal basis. Every local or accidental congregation of

to deal with evidence that is purely archaeological. But in general I imagine the Cretan religion to be a development from the religion described in my first essay, affected both by the change in social structure from village to sea-empire and by foreign, especially Egyptian, influences. No doubt the Achaean gods were influenced on their side by Cretan conceptions, though perhaps not so much as Ionia was. Cf. the Cretan influences in Ionian vase-painting, and e.g. A. B. Cook on 'Cretan Axe-cult outside Crete', Transactions of the Third International Congress for the History of Religion, ii. 184. See also Sir A. Evans's striking address on 'The Minoan and Mycenaean Element in Hellenic Life', just published in F. H. S. xxxii. 277-297.

1 See R. G. F., pp. 78-80. 
people who wish to act together have to invent an imaginary common ancestor. The clash between the old tribal traditions that have lost their meaning, though not their sanctity, and the new duties imposed by the actual needs of the Polis, leads to many strange and interesting compromises. The famous constitution of Cleisthenes shows several. An old proverb expresses well the ordinary feeling on the subject :

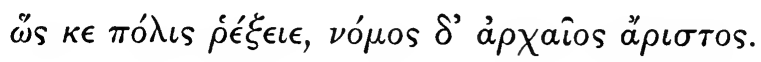

'Whatever the City may do; but the old custom is the best.'

Now in the contest between city and tribe, the Olympian gods had one great negative advantage. They were not tribal or local, and all other gods were. They were by this time international, with no strong roots anywhere except where one of them could be identified with some native god; they were full of fame and beauty and prestige. They were ready to be made 'Poliouchoi', 'City-holders', of any particular city, still more ready to be 'Hellânioi', patrons of all Hellas.

In the working out of these three aims the Olympian religion achieved much : in all three it failed. The moral expurgation failed owing to the mere force of inertia possessed by old religious traditions and local cults. We must remember how weak any central government was in ancient civilization. The power and influence of a highly civilized society were apt to end a few miles outside its city wall. All through 
the backward parts of Greece obscene and cruel rites lingered on, the darker and worse the further they were removed from the full light of Hellenism.

But in this respect the Olympian Religion did not merely fail : it did worse. To make the elements of a nature-religion human is inevitably to make them vicious. There is no great moral harm in worshipping a thunderstorm, even though the lightning strikes the good and evil quite recklessly. There is no need to pretend that the Lightning is exercising a wise and righteous choice. But when once you worship an imaginary quasi-human being who throws the lightning, you are in a dilemma. Either you have to admit that you are worshipping and flattering a being with no moral sense, because he happens to be dangerous, or else you have to invent reasons for his wrath against the people who happen to be struck. And they are pretty sure to be bad reasons. The god, if personal, becomes capricious and cruel.

When the Ark of Israel was being brought back from the Philistines, the cattle slipped by the threshing floor of Nachon, and the holy object was in danger of falling. A certain Uzzah, as we all know, sprang forward to save it and was struck dead for his pains. Now, if he was struck dead by the sheer holiness of the tabu object, the holiness stored inside it like so much electricity, his death was a misfortune, an interesting accident, and no more. ${ }^{1}$ But when it is made into the deliberate act of an anthropomorphic god, who

12 Sam. vi. 6. See S. Reinach, Orpheus, p. 5 (English Translation, p. 4). 
strikes a well-intentioned man dead in explosive rage for a very pardonable mistake, a dangerous element has been introduced into the ethics of that religion. A being who is the moral equal of man must not behave like a charge of dynamite.

Again, to worship emblems of fertility and generation, as was done in agricultural rites all through the Aegean area, is in itself an intelligible and not necessarily a degrading practice. But when those emblems are somehow humanized, and the result is an anthropomorphic god of enormous procreative power and innumerable amours, a religion so modified has received a death-blow. The step that was meant to soften its grossness has resulted in its moral degradation. This result was intensified by another well-meant effort at elevation. The leading tribes of central Greece were, as we have mentioned, apt to count their descent from some heroine-ancestress. Her consort was sometimes unknown and, in a matrilinear society, unimportant. Sometimes he was a local god or river. When the Olympians came to introduce some order and unity among these innumerable local gods, the original tribal ancestor tended, naturally enough, to be identified with Zeus, Apollo, or Poseidon. The unfortunate Olympians, whose system really aimed at purer morals and condemned polygamy and polyandry, are left with a crowd of consorts that would put Solomon to shame. Thus a failure in the moral expurgation was deepened by a failure in the attempt to bring intellectual order into the welter of primitive gods. The only satisfactory end of that effort would have been monotheism. 
If Zeus had only gone further and become completely, once and for all, the father of all life, the scandalous stories would have lost their point and meaning. It is curious how near to monotheism, and to monotheism of a very profound and impersonal type, the real religion of Greece came in the sixth and fifth centuries. Many of the philosophers, Xenophanes, Parmenides and others, asserted it clearly or assumed it without hesitation. Aeschylus, Euripides, Plato, in their deeper moments point the same road. Indeed a metaphysician might hold that their theology is far deeper than that to which we are accustomed, since they seem not to make any particular difference between oi $\theta \epsilon o i$ and

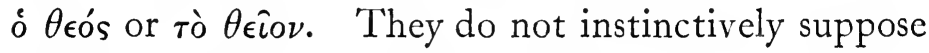
that the human distinctions between 'he' and 'it', or between 'one' and 'many', apply to the divine. Certainly Greek monotheism, had it really carried the day, would have been a far more philosophic thing than the tribal and personal monotheism of the Hebrews. But unfortunately too many hardcaked superstitions, too many tender and sensitive associations, were linked with particular figures in the pantheon or particular rites which had brought the worshippers religious peace. If there had been some Hebrew prophets about, and a tyrant or two, progressive and bloody-minded, to agree with them, polytheism might perhaps actually have been stamped out in Greece at one time. But Greek thought, always sincere and daring, was seldom brutal, seldom ruthless or cruel. The thinkers of the great period felt their own way gently to the Holy of Holies, and 
did not try to compel others to take the same way. Greek theology, whether popular or philosophical, seldom denied any god, seldom forbade any worship. What it tried to do was to identify every new god with some aspect of one of the old ones, and the result was naturally confusion. Apart from the Epicurean school, which though powerful was always unpopular, the religious thought of later antiquity for the most part took refuge in a sort of apotheosis of good taste, in which the great care was not to hurt other people's feelings, or else it collapsed into helpless mysticism.

The attempt to make Olympianism a religion of the Polis failed also. The Olympians did not belong to any particular city: they were too universal; and no particular city had a very positive faith in them. The actual Polis was real and tangible, the Homeric gods a little alien and literary. 'The City herself was a most real power; and the true gods of the City, who had grown out of the soil and the wall, were simply the City herself in her eternal and personal aspect, as mother and guide and lawgiver, the worshipped and beloved being whom each citizen must defend even to the death. As the Kouros of his day emerged from the social group of Kouroi, or the Aphiktor from the

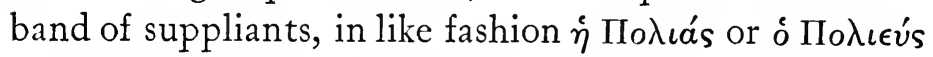
emerged as a personification or projection of the city.

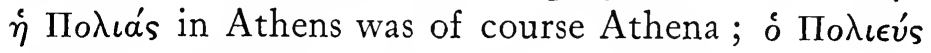
might as well be called Zeus as anything else. In reality such beings fall into the same class as the hero Argos or ' Korinthos son of Zeus'. The City worship was narrow; yet to broaden it was, except in some 
rare minds, to sap its life. The ordinary man finds it impossible to love his next-door neighbours except by hating those who are next-door-but-one.

It proved difficult even in a city like Athens to have gods that would appeal to the loyalty of all Attica. On the Acropolis at Athens there seem originally to have been Athena and some Kouros corresponding with her, some Waterer of the earth, like Erechtheus. Then as Attica was united and brought under the lead of its central city, the gods of the outlying districts began to claim places on the Acropolis. Pallas, the thundermaid of Pallene in the south, came to form a joint personality with Athena. Oinoe, a town in the northeast, on the way from Delos to Delphi, had for its special god a 'Pythian Apollo'; when Oinoe became Attic a place for the Pythian Apollo had to be found on the Acropolis. Dionysus came from Eleutherae, Demeter and Korê from Eleusis, Theseus himself perhaps from Marathon or even from Trozên. They were all given official residences on Athena's rock, and Athens in return sent out Athena to new temples built for her in Prasiae and Sunion and various colonies. ${ }^{1}$ This development came step by step and grew out of real worships. It was quite different from the wholesale adoption of a body of non-national, poetical gods: yet even this development was too artificial, too much stamped with the marks of expediency and courtesy and compromise. It could not live. The personalities of such gods vanish away; their prayers become prayers to 'all

1 Cf. Sam Wide in Gercke and Norden's Handbuch, ii. 217-I9. 
gods and goddesses of the City'- $\theta \epsilon o$ is кai $\theta \epsilon \hat{r} \sigma \iota \pi \hat{a} \sigma \iota$ $\kappa a i \pi a ́ \sigma \eta \sigma \iota$; those who remain, chiefly Athena and Theseus, only mean Athens.

What then, amid all this failure, did the Olympian religion really achieve? First, it debarbarized the worship of the leading states of Greece-not of all Greece, since antiquity had no means of spreading knowledge comparable to ours. It reduced the horrors of the 'Urdummheit', for the most part, to a romantic memory, and made religion no longer a mortal danger to humanity. Unlike many religious systems, it generally permitted progress; it encouraged not only the obedient virtues but the daring virtues as well. It had in it the spirit that saves from disaster, that knows itself fallible and thinks twice before it hates and curses and persecutes. It wrapped religion in Sophrosynê.

Again, it worked for concord and fellow-feeling throughout the Greek communities. It is, after all, a good deal to say, that in Greek history we find almost no warring of sects, no mutual tortures or even blasphemies. With many ragged edges, with many weaknesses, it built up something like a united Hellenic religion to stand against the 'beastly devices of the heathen'. And after all, if we are inclined on the purely religious side to judge the Olympian system harshly, we must not forget its sheer beauty. Truth, no doubt, is greater than beauty. But in many matters beauty can be attained and truth cannot. All we know is that when the best minds seek for truth the result is apt to be beautiful. It was a great thing that men 
should envisage the world as governed, not by Giants and Gorgons and dealers in eternal torture, but by some human and more than human Understanding ( $\left.\Xi v^{\prime} \nu \epsilon \iota \iota\right),{ }^{1}$ by beings of quiet splendour like many a classical Zeus and Hermes and Demeter. If Olympianism was not a religious faith, it was at least a vital force in the shaping of cities and societies which remain after two thousand years a type to the world of beauty and freedom and high endeavour. Even the stirring of its ashes, when they seemed long cold, had power to produce something of the same result; for the classicism of the Italian Renaissance is a child, however fallen, of the Olympian spirit.

Of course I recognize that beauty is not the same as faith. There is, in one sense, far more faith in some hideous miracle-working icon which sends out starving peasants to massacre Jews than in the Athena of Phidias. Yet, once we have rid our minds of trivial mythology, there is religion in Athena also. Athena is an ideal, an ideal and a mystery ; the ideal of wisdom, of incessant labour, of almost terrifying purity, seen through the light of some mystic and spiritual devotion like, but transcending, the love of man for woman. Or, if the way of Athena is too hard for us common men, it is not hard to find a true religious ideal in such a figure as Persephone. In Persephone there is more of pathos and of mystery. She has more recently entered the calm

1 The $\Xi v \dot{v} \epsilon \sigma \iota s$ to which Euripides prays in Ar. Frogs, 893, and in which the Chorus finds it hard to believe, Hippolytus, i 105. Cf. Iph. Aul. 394, I189; Herc. 655; also the ideas in Suppl. 203, Eur. Fr. 52, 9,

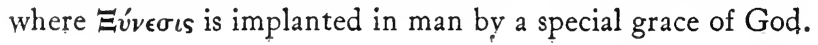


ranks of Olympus; the old liturgy of the dying and re-risen Year-bride still clings to her. If Religion is that which brings us into relation with the great world-forces, there is the very heart of life in this home-coming Bride of the underworld, life with its broken hopes, its disaster, its new-found spiritual joy: life seen as Mother and Daughter, not a thing continuous and unchanging but shot through with parting and death, life as a great love or desire ever torn asunder and ever renewed.

'But stay,' a reader may object: ' is not this the Persephone, the Athena, of modern sentiment? Are these figures really the goddesses of the Iliad and of Sophocles?' 'The truth is, I think, that they are neither the one nor the other. They are the goddesses of ancient reflection and allegory; the goddesses, that is, of the best and most characteristic worship that these idealized creations awakened. What we have treated hitherto as the mortal weakness of the Olympians, the fact that they have no roots in any particular soil, little hold on any definite primaeval cult, has turned out to be their peculiar strength. We must not think of allegory as a late post-classical phenomenon in Greece. It begins at least as early as Pythagoras and Heraclitus, perhaps as early as Hesiod: for Hesiod seems sometimes to be turning allegory back into myth. The Olympians, cut loose from the soil, enthroned only in men's free imagination, have two special regions which they have made their own : mythology and allegory. The mythology drops for the most part very early out of practical religion. Even in Homer we find it 
expurgated; in Pindar, Aeschylus and Xenophanes it is expurgated, denied and allegorized. The myths survive chiefly as material for literature, the shapes of the gods themselves chiefly as material for art. They are both of them objects not of belief but of imagination. Yet when the religious imagination of Greece deepens it twines itself still round these gracious and ever-moving shapes; the Zeus of Aeschylus moves on into the Zeus of Plato or of Cleanthes or of Marcus Aurelius. Hermes, Athena, Apollo, all have their long spiritual history. They are but little impeded by the echoes of the old monstrous mythology; still less by any local roots or sectional prejudices or compulsory details of ritual. As the more highly educated mind of Greece emerged from a particular, local, tribal, conception of religion, the old denationalized Olympians were ready to receive her.

The real religion of the fifth century was, as we have said, a devotion to the City itself. It is expressed often in Aeschylus and Sophocles, again and again with more discord and more criticism in Euripides and Plato; for the indignant blasphemies of the Gorgias and the Troades bear the same message as the ideal patriotism of the Republic. It is expressed best perhaps, and that without mention of the name of a single god, in the great Funeral Speech of Pericles. It is higher than most modern patriotism because it is set upon higher ideals. It is more fervid because the men practising it lived habitually nearer to the dangerpoint, and, when they spoke of dying for the City, spoke of a thing they had faced last week and might 
face again to-morrow. It was more religious because of the unconscious mysticism in which it is clothed even by such hard heads as Pericles and Thucydides, the mysticism of men in the presence of some fact for which they have no words great enough. Yet for all its intensity it was condemned by its mere narrowness. By the fourth century the average Athenian must have recognized what philosophers had recognized long before, that a religion, to be true, must be universal and not the privilege of a particular people. As soon as the Stoics had proclaimed the world to be 'one great City of gods and men', the only Gods with which Greece could satisfactorily people that City were the idealized band of the old Olympians.

'They are artists' dreams, ideals, allegories; they are symbols of something beyond themselves. They are Gods of half-rejected tradition, of unconscious make-believe, of aspiration. They are gods to whom doubtful philosophers can pray, with all a philosopher's due caution, as to so many radiant and heart-searching hypotheses. They are not gods in whom any one believes as a hard fact. Does this condemn them? Or is it just the other way? Is it perhaps that the difference between Religion and Superstition lies exactly in this, that Superstition degrades its worship by turning its beliefs into so many statements of brute fact, on which it must needs act without question, without striving, without any respect for others or any desire for higher or fuller truth? It is only an accident -though perhaps an invariable accident-that all the supposed facts are false. In Religion, however precious

P. F. 618 
you may consider the truth you draw from it, you know that it is a truth seen dimly, and possibly seen by others better than by you. You know that all your creeds and definitions are merely metaphors, attempts to use human language for a purpose for which it was never made. Your concepts are, by the nature of things, inadequate; the truth is not in you but beyond you, a thing not conquered but still to be pursued. Something like this, I take it, was the character of the Olympian Religion in the higher minds of later Greece. Its gods could awaken man's worship and strengthen his higher aspirations; but at heart they knew themselves to be only metaphors. As the most beautiful image carved by man was not the god, but only a symbol, to help towards conceiving the god; ${ }^{1}$

1 Cf. the beautiful defence of idols by Maximus of 'Tyre, Or. viii (in Wilamowitz's Lesebuch, ii, $338 \mathrm{ff}$.). I quote the last paragraph :

' God Himself, the father and fashioner of all that is, older than the Sun or the Sky, greater than time and eternity and all the flow of being, is unnameable by any lawgiver, unutterable by any voice, not to be seen by any eye. But we, being unable to apprehend His essence, use the help of sounds and names and pictures, of beaten gold and ivory and silver, of plants and rivers, mountain-peaks and torrents, yearning for the knowledge of Him, and in our weakness naming all that is beautiful in this world after His nature-just as happens to earthly lovers. To them the most beautiful sight will be the actual lineaments of the beloved, but for remembrance' sake they will be happy in the sight of a lyre, a little spear, a chair, perhaps, or a running-ground, or anything in the world that wakens the memory of the beloved. Why should I further examine and pass judgement about Images? I.et

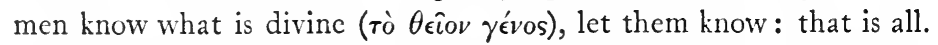
If a Greek is stirred to the remembrance of God by the art of Pheidias, an Egyptian by paying worship to animals, another man by a river, 
so the god himself, when conceived, was not the reality but only a symbol to help towards conceiving the reality. That was the work set before them. Meantime they issued no creeds that contradicted knowledge, no commands that made man sin against his own inner light.

another by fire-I have no anger for their divergences; only let them know, let them love, let them remember.' 



\section{III}

\section{THE FAILURE OF NERVE}





\section{III}

\section{THE FAILURE OF NERVE}

ANy one who turns from the great writers of classical Athens, say Sophocles or Aristotle, to those of the Christian era must be conscious of a great difference in tone. There is a change in the whole relation of the writer to the world about him. The new quality is not specifically Christian : it is just as marked in the Gnostics and Mithras-worshippers as in the Gospels and the Apocalypse, in Julian and Plotinus as in Gregory and Jerome.) It is hard to describe. It is a rise of asceticism, of mysticism, in a sense, of pessimism ; a loss of self-confidence, of hope in this life and of faith in normal human effort; a despair of patient inquiry, a cry for infallible revelation; an indifference to the welfare of the state, a conversion of the soul to God. It is an atmosphere in which the aim of the good man is not so much to live justly, to help the society to which he belongs and enjoy the esteem of his fellow creatures; but rather, by means of a burning faith, by contempt for the world and its standards, by ecstasy, suffering and martyrdom, to be granted pardon for his unspeakable unworthiness, his immeasurable sins. There is an intensifying of certain spiritual emotions; an increase of sensitiveness, a failure of nerve. 
Now this antithesis is often exaggerated by the admirers of one side or the other. A hundred people write as if Sophocles had no mysticism and practically speaking no conscience. Half a dozen retort as if St. Paul had no public spirit and no common sense. I have protested often against this exaggeration; but, stated reasonably, as a change of proportion and not a creation of new hearts, the antithesis is certainly based on fact. The histurical reasons for it are suggested above, in the first of these essays.

My description of this complicated change is, of course, inadequate, but not, I hope, one-sided. I do not depreciate the religions that followed on this movement by describing the movement itself as a 'failure of nerve'. Mankind has not yet decided which of two opposite methods leads to the fuller and deeper knowledge of the world: the patient and sympathetic study of the good citizen who lives in it, or the ecstatic vision of the saint who rejects it. But probably most Christians are inclined to believe that without some failure and sense of failure, without a contrite heart and conviction of sin, man can hardly attain the religious life. I can imagine an historian of this temper believing that the period we are about to discuss was a necessary softening of human pride, a Preparatio Evangelica. ${ }^{1}$

1 Mr. Marett has pointed out that this conception has its roots deep in primitive human nature: The Birth of Humility, Oxford, I910, p. 17. 'It would, perhaps, be fanciful to say that man tends to run away from the sacred as uncanny, to cower before it as secret, and to prostrate himself before it as tabu. On the other hand, it seems plain 
I am concerned in this paper with the lower country lying between two great ranges. The one range is Greek Philosophy, culminating in Plato, Aristotle, the Porch, and the Garden; the other is Christianity, culminating in St. Paul and his successors. The one is the work of Hellas, using some few foreign elements ; the second is the work of Hellenistic culture on a Hebrew stock. The books of Christianity are Greek, the philosophical background is Hellenistic, the result of the interplay, in the free atmosphere of Greek philosophy, of religious ideas derived from Egypt, Anatolia, Syria, and Babylon. The preaching is carried on in Greek among the Greek-speaking workmen of the great manufacturing and commercial cities.

that to these three negative qualities of the sacred taken together there corresponds on the part of man a certain negative attitude of mind. Psychologists class the feelings bound up with flight, cowering, and prostration under the common head of "asthenic emotion". In plain English they are all forms of heart-sinking, of feeling unstrung. This general type of innate disposition would seem to be the psychological basis of Humility. Taken in its social setting, the emotion will, of course, show endless shades of complexity; for it will be excited, and again will find practical expression, in all sorts of ways. Under these varying conditions, however, it is reasonable to suppose that what Mr. McDougall would call the "central part" of the experienceremains very much the same. In face of the sacred the normal man is visited by a heart-sinking, a wave of asthenic emotion.' Mr. Marett continues: 'If that were all, however, Religion would be a matter of pure fear. But it is not all. There is yet the positive side of the sacred to be taken into account.' It is worth remarking also that Schleiermacher (1767-1834) placed the essence of religion in the feeling of absolute dependence without attempting to define the object towards which it was directed. 
The first preachers are Jews: the central scene is set in Jerusalem. I wish in this essay to indicate how a period of religious history, which seems broken, is really continuous, and to trace the lie of the main valleys which lead from the one range to the other, through a large and imperfectly explored territory.

The territory in question is the so-called Hellenistic Age, the period during which the Schools of Greece were 'hellenizing' the world. It is a time of great enlightenment, of vigorous propaganda, of high importance to history. It is a time full of great names : in one school of philosophy alone we have Zeno, Cleanthes, Chrysippus, Panaetius, Posidonius. Yet, curiously enough, it is represented in our tradition by something very like a mere void. There are practically no complete books preserved, only fragments and indirect quotations. Consequently in the search for information about this age we must throw our nets wide. Beside books and inscriptions of the Hellenistic period proper I have drawn on Cicero, Pliny, Seneca, and the like for evidence about their teachers and masters. I have used many Christian and Gnostic documents and works like the Corpus of Hermetic writings and the Mithras Liturgy. Among modern writers I must acknowledge a special debt to the researches of Dieterich, Cumont, Bousset, Wendland, and Reitzenstein.

The Hellenistic Age seems at first sight to have entered on an inheritance such as our speculative Anarchists sometimes long for, a tabula rasa, on which a new and highly gifted generation of thinkers might 
write clean and certain the book of their discoveries about life-what Herodotus would call their 'Historiê'. For, as we have seen in the last essay, it is clear that by the time of Plato the traditional religion of the Greek states was, if taken at its face value, a bankrupt concern. There was hardly one aspect in which it could bear criticism ; and in the kind of test that chiefly matters, the satisfaction of men's ethical requirements and aspirations, it was if anything weaker than elsewhere. Now a religious belief that is scientifically preposterous may still have a long and comfortable life before it. Any worshipper can suspend the scientific part of his mind while worshipping. But a religious belief that is morally contemptible is in serious danger, because when the religious emotions surge up the moral emotions are not far away. And the clash cannot be hidden.

This collapse of the traditional religion of Greece might not have mattered so much if the form of Greek social life had remained. If a good Greek had his Polis, he had an adequate substitute in most respects for any mythological gods. But the Polis too fell with the rise of Macedon. It fell, perhaps, not from any special spiritual fault of its own; it had few faults except its fatal narrowness; but simply because there now existed another social whole, which, whether higher or lower in civilization, was at any rate utterly superior in brute force and in money. Devotion to the Polis lost its reality when the Polis, with all that it represented of rights and laws and ideals of Life, lay at the mercy of a military despot, who might, of course, 
be a hero, but might equally well be a vulgar sot or a corrupt adventurer.

What the succeeding ages built upon the ruins of the Polis is not our immediate concern. In the realm of thought, on the whole, the Polis triumphed. Aristotle based his social theory on the Polis, not the nation. Dicaearchus, Didymus, and Posidonius followed him, and we still use his language. Rome herself was a Polis, as well as an Empire. And Professor Haverfield has pointed out that a City has more chance of taking in the whole world to its freedoms and privileges than a Nation has of making men of alien birth its compatriots. A Jew of Tarsus could easily be granted the civic rights of Rome: he could never have been made an Italian or Frenchman. The Stoic ideal of the World as 'one great City of Gods and Men' has not been surpassed by any ideal based on the Nation.

What we have to consider is the general trend of religious thought from, say, the Peripatetics to the Gnostics. It is a fairly clear history. A soil once teeming with wild weeds was to all appearance swept bare and made ready for new sowing; skilled gardeners chose carefully the best of herbs and plants and tended the garden sedulously. But the bounds of the garden kept spreading all the while into strange untended ground, and even within the original walls the weeding had been hasty and incomplete. At the end of a few generations all was a wilderness of weeds again, weeds rank and luxuriant and sometimes extremely beautiful, with a half-strangled garden flower or two gleaming 
here and there in the tangle of them. Does that comparison seem disrespectful to religion? Is philosophy all flowers and traditional belief all weeds? Well, think what a weed is. It is only a name for all the natural wild vegetation which the earth sends up of herself, which lives and will live without the conscious labour of man. The flowers are what we keep alive with difficulty; the weeds are what conquer us.

It has been well observed by Zeller that the great weakness of all ancient thought, not excepting Socratic thought, was that instead of appealing to objective experiment it appealed to some subjective sense of fitness. There were exceptions of course: Democritus, Eratosthenes, Hippocrates, and to a great extent Aristotle. But in general there was a strong tendency to follow Plato in supposing that people could really solve questions by an appeal to their inner consciousness. One result of this, no doubt, was a tendency to lay too much stress on mere agreement. It is obvious, when one thinks about it, that quite often a large number of people who know nothing about a subject will all agree and all be wrong. Yet we find the most radical of ancient philosophers unconsciously dominated by the argument ex consensu gentium. It is hard to find two more uncompromising thinkers than Zeno and Epicurus. Yet both of them, when they are almost free from the popular superstitions, when they have constructed complete systems which, if not absolutely logic-proof, are calculated at least to keep out the weather for a century or so, open curious side-doors at the last moment and let in all 
the gods of mythology. ${ }^{1}$ True, they are admitted as suspicious characters, and under promise of good behaviour. Epicurus explains that they do not and cannot do anything whatever to anybody; Zeno explains that they are not anthropomorphic, and are only symbols or emanations or subordinates of the allruling Unity; both parties get rid of the myths. But the two great reformers have admitted a dangerous principle. The general consensus of humanity, they say, shows that there are gods, and gods which in mind, if not also in visual appearance, resemble man. Epicurus succeeded in barring the door, and admitted nothing more. But the Stoics presently found themselves admitting or insisting that the same consensus proved the existence of daemons, of witchcraft, of divination, and when they combined with the Platonic school, of more dangerous elements still.

I take the Stoics and Epicureans as the two most radical schools. On the whole both of them fought steadily and strongly against the growth of superstition, or, if you like to put it in other language, against the dumb demands of man's infra-rational nature. The glory of the Stoics is to have built up a religion of extraordinary nobleness; the glory of the Epicureans is to have upheld an ideal of sanity and humanity stark upright amid a reeling world, and, like the old Spartans, never to have yielded one inch of ground to the common foe.

1 Usener, Epicurca (1887), pp. 232 ff.; Diels, Doxograpbi Graeci (1879), p. 306; Arnim, Stoicorum Veterum Fragmenta (1903-5), Chrysippus I0I4, IOIg. 
The great thing to remember is that the mind of man cannot be enlightened permanently by merely teaching him to reject some particular set of superstitions. There is an infinite supply of other superstitions always at hand; and the mind that desires such things-that is, the mind that has not trained itself to the hard discipline of reasonableness and honesty, will, as soon as its devils are cast out, proceed to fill itself with their relations.

Let us first consider the result of the mere denial of the Olympian religion. The essential postulate of that religion was that the world is governed by a number of definite personal gods, possessed of a human sense of justice and fairness and capable of being influenced by normal human motives. In general, they helped the good and punished the bad, though doubtless they tended too much to regard as good those who paid them proper attention and as bad those who did not.

Speaking broadly, what was left when this conception proved inadequate? If it was not these personal gods who made things happen, what was it? If the Tower of Siloam was not deliberately thrown down by the gods so as to kill and hurt a carefully collected number of wicked people, while letting the good escape, what was the explanation of its falling? The answer is obvious, but it can be put in two ways. You can either say: "It was just chance that the Tower fell at that particular moment when So-and-so was under it.' Or you can say, with rather more reflection but not any more common sense: 'It fell because of 
a definite chain of causes, a certain degree of progressive decay in the building, a certain definite pressure, \&c. It was bound to fall.'

There is no real difference in these statements, at least in the meaning of those who ordinarily utter them. Both are compatible with a reasonable and scientific view of the world. But in the Hellenistic Age, when Greek thought was spreading rapidly and superficially over vast semi-barbarous populations whose minds were not ripe for it, both views turned back instinctively into a theology as personal as that of the Olympians. It was not, of course, Zeus or Apollo who willed this; every one knew so much: it happened by Chance. That is, Chance or Fortune willed it. And Tuchê became a goddess like the rest. The great catastrophes, the great transformations of the mediterranean world which marked the Hellenistic period, had a strong influence here. If Alexander and his generals had practised some severely orthodox Macedonian religion, it would have been easy to see that the Gods of Macedon were the real rulers of the world. But they most markedly did not. They accepted hospitably all the religions that crossed their path. Some power or other was disturbing the world, that was clear. It was not exactly the work of man, because sometimes the good were exalted, sometimes the bad; sometimes the Greek, sometimes the barbarian. It was just Fortune. Happy is the man who knows how to placate Fortune and make her smile upon him !

It is worth remembering that the best seed-ground for superstition is a society in which the fortunes of 
men seem to bear practically no relation to their merits and efforts. A stable and well-governed society does tend, speaking roughly, to ensure that the Virtuous and Industrious Apprentice shall succeed in life, while the Wicked and Idle Apprentice fails. And in such a society people tend to lay stress on the reasonable or visible chains of causation. But in a country suffering from earthquakes or pestilences, in a court governed by the whim of a despot, in a district which is habitually the seat of a war between alien armies, the ordinary virtues of diligence, honesty, and kindliness seem to be of little avail. The only way to escape destruction is to win the favour of the prevailing powers, take the side of the strongest invader, flatter the despot, placate the Fate or Fortune or angry god that is sending the earthquake or the pestilence. The Hellenistic period pretty certainly falls in some degree under all of these categories. And one result is the sudden and enormous spread of the worship of Fortune. Of course there was always a protest. There is the famous

Nullum numen babes si sit prudentia: nos te, Nos facimus, Fortuna, deam,

taken by Juvenal from the Greek. There are many unguarded phrases and at least three corrections in Polybius. 1 Most interesting of all perhaps there is the first oration of Plutarch on the Fortune of Alexander. ${ }^{2}$

1 Juv. x. 365 f.; Polyb. ii. 38.5 ; x. 5.8 ; xviii. II. 5 .

2 Cf. also his Consolatio ad Apollonium. The earliest text is perhaps the interesting fragment of Demetrius of Phalerum (fr. I9, 


\section{A sentence in Pliny's Natural History, ii. 22, seems to go back to Hellenistic sources.}

'Throughout the whole world, at every place and hour, by every voice Fortune alone is invoked and her name spoken: she is the one defendant, the one culprit, the one thought in men's minds, the one object of praise, the one cause. She is worshipped with insults, counted as fickle and often as blind, wandering, inconsistent, elusive, changeful, and friend of the unworthy.... We are so much at the mercy of chance that Chance is our god.'

The word used is first Fortuna and then Sors. This shows how little real difference there is between the in F. H. G. ii. 368), written about 317 B.c. It is quoted with admiration by Polybius xxix. 2I, with reference to the defeat of Perseus of Macedon by the Romans :

'One must often remember the saying of Demetrius of Phalerum... in his Treatise on Fortune ... "If you were to take not an indefinite time, nor many generations, but just the fifty years before this, you could see in them the violence of Fortune. Fifty years ago do you suppose that either the Macedonians or the King of Macedon, or the Persians or the King of Persia, if some God had foretold them what was to come, would ever have believed that by the present time the Persians, who were then masters of almost all the inhabited world, would have ceased to be even a geographical name, while the Macedonians, who were then not even a name, would be rulers of all ? Yet this Fortune, who bears no relation to our method of life, but transforms everything in the way we do not expect and displays her power by surprises, is at the present moment showing all the world that, when she puts the Macedonians into the rich inheritance of the Persian, she has only lent them these good things until she changes her mind about them." Which has now happened in the case of Perseus. The words of Demetrius were a prophecy uttered, as it were, by inspired lips.' 
two apparently contradictory conceptions.- ' Chance would have it so.' 'It was fated to be.' 'The sting of both phrases-their pleasant bitterness when played with, their quality of poison when believed-lies in their denial of the value of human endeavour.

Yet on the whole, as one might expect, the believers in Destiny are a more respectable congregation than the worshippers of Chance. It requires a certain amount of thoughtfulness to rise to the conception that nothing really happens without a cause. It is the beginning, perhaps, of science. Ionic philosophers of the fifth century had laid stress on the 'A $\nu a ́ \gamma \kappa \eta \phi \dot{v} \sigma \iota s,{ }^{1}$, what we should call the Chain of causes in Nature. After the rise of Stoicism Fate becomes something less physical, more related to conscious purpose. It is not Anankê but Heimarmenê. Heimarmenê, in the striking simile of Zeno, ${ }^{2}$ is like a fine thread running through the whole of existence-the world, we must remember, was to the Stoics a live thing-like that invisible thread of life which, in heredity, passes on from generation to generation of living species and keeps the type alive; it runs causing, causing for ever, both the infinitesimal and

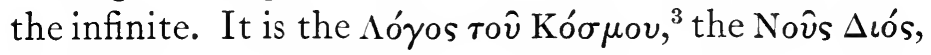
the Reason of the World or the mind of Zeus, rather difficult to distinguish from the Pronoia or Providence, which is the work of God and indeed the very essence of God. Cleanthes in one of his finest hymns prays to $\dot{\eta} \pi \epsilon \pi \rho \omega \mu \epsilon \dot{\epsilon} \eta$ - the Path that is Ordained. ${ }^{4}$

${ }^{1}$ Eur., $\mathcal{T r o}_{\text {ro }}$ 886. Literally it means 'The Compulsion in the way Things grow'.

${ }^{3}$ Chrysippus, fr. 913, Arnim.

2 Zeno, fr. 87, Arnim.

${ }^{4}$ Cleanthes, 527, Arnim. 
That is a noble conception. But the vulgar of course can turn Kismet into a stupid idol, as easily as they can Fortune. And Epicurus may have been right when he exclaimed that he would sooner be a slave to the old gods of the vulgar, than to the Destiny of the philosophers. ${ }^{1}$

So much for the result in superstitious minds of the denial, or rather the removal, of the Olympian Gods. It landed men in the worship of Fortune or of Fate.

Next, let us consider what happened when, instead of merely rejecting the Gods en masse, people tried carefully to collect what remained of religion after the Olympian system fell.

Aristotle himself gives us a fairly clear answer. $\mathrm{He}$ held that the origins of man's knowledge ( the Divine were twofold, ${ }^{2}$ the phenomena of the sky and the phenomena of the human soul. It is very much what Kant found two thousand years later. The spectacle of the vast and ordered movements of the heavenly bodies are compared by him in a famous fragment with the marching forth of Homer's armies before Troy. Behind such various order and strength there must surely be a conscious mind capable

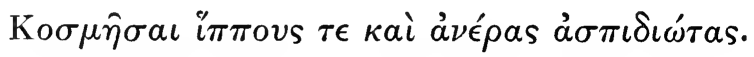

To order steeds of war and mailèd men.

It is only a step from this to regarding the sun, moon, and stars as themselves divine, and it is a step which

${ }^{1}$ Epicurus, Third Letter. Usener, p. 65, 12 = Diog. La. x. I34.

2 Aristotle, fr. I 2 ff. 
both Plato and Aristotle, following Pythagoras and followed by the Stoics, take with confidence. Chrysippus gives practically the same list of gods: " the Sun, Moon, and Stars and Law : and men who have turned into Gods.' 1 Both the wandering stars and the fixed stars are ' animate beings, divine and eternal', selfacting subordinate gods. As to the divinity of the soul or the mind of man, the earlier generations are shy about it. But in the later Stoics it is itself a portion of the divine life. It shows this ordinarily by its power

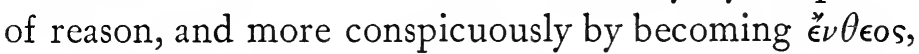
or ' filled with God', in its exalted moments of prevision, ecstasy, and prophetic dreams. If reason itself is divine, there is something else in the soul which is even higher than reason or at least more surprisingly divine.

Let us follow the history of both these remaining substitutes for the Olympian gods.

First for the Heavenly bodies. If they are to be made divine, we can hardly stop there. The Earth is also a divine being. Old tradition has always said so, and Plato has repeated it. And if Earth is divine, so surely are the other elements, the Stoicheia, Water, Air, and above all, Fire. For the Gods themselves are said by Plato to be made of fire, and the Stars visibly are so. Though perhaps the heavenly Fire is really not our Fire at all, but a $\pi \epsilon \mu \pi \tau o \nu \sigma \hat{\omega} \mu \alpha$, a 'Fifth Body', seeing that it seems not to burn nor the Stars to be consumed.

This is persuasive enough and philosophic; but

1 e.g. Chrysippus, fr. 1076, Arnim. 
whither has it led us? Back to the Olympians, or rather behind the Olympians; as St. Paul puts it (Gal. iv. 9), to ' the beggarly elements'. 'The old Korê, or Earth Maiden and Mother, seems to have held her own unshaken by the changes of time all over the Aegean area. She is there in prehistoric Crete with her two lions; with the same lions orientalized in Olympia and Ephesus; in Sparta with her great marsh birds; in Boeotia with her horse. She runs riot in a number of the Gnostic systems both pre-Christian and postChristian. She forms a divine triad with the Father and the Son: that is ancient and natural. But she also becomes the Divine Wisdom, Sophia, the Divine Truth, Aletheia, the Holy Breath or Spirit, the Pneuma. Since the word for 'spirit' is neuter in Greek and masculine in Latin, this last is rather a surprise. It is explained when we remember that in Hebrew the word for Spirit, 'Ruah,' is mostly feminine. In the meantime let us notice one curious development in the life of this goddess. In the old religion of Greece and Western Asia, she begins as a Maiden, then in fullness of time becomes a mother. There is evidence also for a third stage, the widowhood of withering autumn. ${ }^{1}$ To the classical Greek this motherhood was quite as it should be, a due fulfilment of normal functions. But to the Gnostic and NeoPlatonist it connoted a 'fall', a passage from the glory of Virginity to a state of Sin. The Korê becomes a fallen Virgin, sometimes a temptress or even a female devil; sometimes she has to be saved by her Son the 1 Themis, p. I8o, n. I. 
Redeemer. ${ }^{1}$ As far as I have observed, she loses most of her earthly agricultural quality, though as Selene or even Helen she keeps up her affinity with the Moon.

Almost all the writers of the Hellenistic Age agree in regarding the Sun, Moon and Stars as gods. The rationalists Hecataeus and Euhemerus, before going on to their deified men, always start with the heavenly bodies. When Plutarch explains in his beautiful and kindly way that all religions are really attempts towards the same goal, he clinches his argument by observing that we all see the same Sun and Moon though we call them by different names in all languages. ${ }^{2}$ But the belief does not seem to have had much religious intensity in it, until it was reinforced by two alien influences.

First, we have the ancient worship of the Sun, implicit, if not explicit, in a great part of the oldest Greek rituals, and then idealized by Plato in the Republic, where the Sun is the author of all light and life in the material world, as the Idea of Good is in the ideal world. This worship came gradually into contact with the traditional and definite Sun-worship of Persia. The final combination took place curiously late. It was the Roman conquests of Cilicia, Cappadocia, Commagene, and Armenia that gave the decisive

1 Bousset, Hauptprobleme der Gnosis, 1907, pp. I3, 21, 26, 81, \&c.; pp. 332 ff. She becomes Helen in the beautiful myth of the Simonian Gnostics-a Helen who has forgotten her name and race, and is a slave in a brothel in Tyre. Simon discovers her, gradually brings back her memory and redeems her. Irenaeus, i. 23. 2.

2 De Iside et Osiride, 67. (He distinguishes them from the real God, however, just as Sallustius would.) 
moment. ${ }^{1}$ To men who had wearied of the myths of the poets, who could draw no more inspiration from their Apollo and Hyperion, but still had the habits and the craving left by their old Gods, a fresh breath

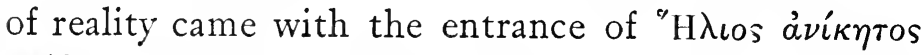
Miopas, 'Mithras, the Unconquered Sun.' But long before the triumph of Mithraism as the military religion of the Roman frontier, Greek literature is permeated with a kind of intense language about the Sun, which seems derived from Plato. ${ }^{2}$ In later times, in the fourth century A.D. for instance, it has absorbed some more full-blooded and less critical element as well.

Secondly, all the seven planets. 'These had a curious history. The planets were of course divine and living bodies, so much Plato gave us. 'Then come arguments and questions scattered through the Stoic and eclectic literature. Is it the planet itself that is divine, or is the planet under the guidance of a divine spirit? The latter seems to win the day. Anthropomorphism has stolen back upon us: we can use the old language and speak simply of the planet Mercury as 'E $\rho \mu o \hat{v} \alpha \dot{a} \sigma \tau \eta^{\prime} \rho$. It is the star of Hermes, and Hermes is the spirit who guides it. $^{3}$ Even Plato in his old age had much to

1 Mithras was worshipped by the Cilician Pirates conquered by Pompey. Plut., Vit. Pomp. 24.

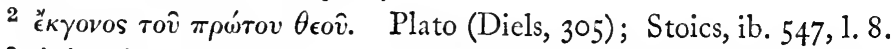

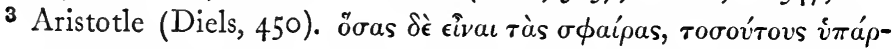

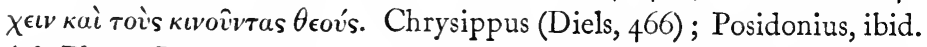
(cf. Plato, Laws, 898 ff.). See Epicurus's Second Letter, especially Usener, pp. $36-47=$ Diog. La. x. 86-104. On the food required by the heavenly bodies cf. Chrysippus, fr. 658-6r, Arnim. 
say about the souls of the seven planets. Further, each planet has its sphere. The Earth is in the centre, then comes the sphere of the Moon, then that of the Sun, and so on through a range of seven spheres. If all things are full of gods, as the wise ancients have said, what about those parts of the sphere in which the shining planet for the moment is not? Are they without god? Obviously not. The whole sphere is filled with innumerable spirits everywhere. It is all Hermes, all Aphrodite. (We are more familiar with the Latin names, Mercury and Venus.) But one part only is visible. The voice of one school, as usual, is raised in opposition. One veteran had seen clearly from the beginning whither all this sort of thing was sure to lead. 'Epicurus approves none of these things.' 1 It was no good his having destroyed the old traditional superstition, if people by deifying the stars were to fill the sky with seven times seven as many objects of worship as had been there before. He allows no Scbwärmerei about the stars. 'They are not divine animate beings, or guided by Gods. Why cannot the astrologers leave God in peace? When their orbits are irregular it is not because they are looking for food. They are just conglomerations of ordinary atoms of air or fire-it does not matter which. They are not even very large-only about as large as they look, or perhaps smaller, since most fires tend to look bigger at a distance. They are not at all certainly everlasting. It is quite likely that the sun comes to an end every day,

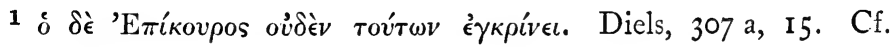
432 a, 10. 
and a new one rises in the morning. All kinds of explanations are possible, and none certain. Móvov ó $\mu \hat{v} \theta$ os $\dot{a} \pi \hat{\epsilon} \sigma \tau \omega$. In any case, as you value your life and your reason, do not begin making myths about them!

On other lines came what might have been the effective protest of real Science, when Aristarchus of Samos (250 в.с.) argued that the earth was not really the centre of the universe, but revolved round the Sun. But his fellow astronomers were against him; Cleanthes the Stoic denounced him for 'disturbing the Hearth of the Universe', and his heresy soon died away.

The planets in their seven spheres surrounding the earth continued to be objects of adoration. They had their special gods or guiding spirits assigned them. Their ordered movements through space, it was held, produce a vast and eternal harmony. It is beautiful beyond all earthly music, this Music of the Spheres, beyond all human dreams of what music might be. The only pity is that-except for a few individuals in trances-nobody has ever heard it. Circumstances seem always to be unfavourable. It may be that we are toofar off, though, considering the vastness of the orchestra, this seems improbable. More likely we are merely deaf to it because it never stops and we have been in the middle of it since we first drew breath. ${ }^{1}$

The planets also become Elements in the Kosmos, Stoicheia. It is significant that in Hellenistic theology the word Stoicheion, Element, gets to mean a Daemon

${ }^{1}$ Pythagoras in Diels, p. 555, 20; the best criticism is in PseudoAristotle, De Caelo, chap. 9 (p. 290 b). 
-as Megethos, Greatness, means an Angel. ${ }^{1}$ But behold a mystery! The word Stoicheia, 'elementa', had long been used for the Greek ABC, and in particular for the seven vowels $a \in \eta \iota 0 v \omega$. That is no chance, no mere coincidence. The vowels are the mystic signs of the Planets; they have control over the planets. Hence strange prayers and magic formulae innumerable.

Even the way of reckoning time changed under the influence of the Planets. Instead of the old division of the month into three periods of nine days, we find gradually establishing itself the week of seven days with each day named after its planet, Sun, Moon, Ares, Hermes, Zeus, Aphrodite, Kronos. The history of the Planet week is given by Dio Cassius, xxxvii. I 8 , in his account of the Jewish campaign of Pompeius. But it was not the Jewish week. The Jews scorned such idolatrous and polytheistic proceedings. It was the old week of Babylon, the original home of astronomy and planet-worship.

For here again a great foreign religion came like water in the desert to minds reluctantly and superficially enlightened, but secretly longing for the old terrors and raptures from which they had been set free. Even in the old days Aeschylus had called the planets 'bright potentates, shining in the fire of heaven', and Euripides had spoken of the 'shaft hurled from a star'. ${ }^{2}$ But we are told that the first teaching of astrology in

${ }^{1}$ See Diels, Elementum, I899, p. 17. These magic letters are still used in the Roman ritual for the consecration of churches.

2 Aesch., Ag. 6; Eur., Hip. 53 O. 
Hellenic lands was in the time of Alexander, when Berôssos the Chaldaean set up a school in Cos. And the philosopher Theophrastus is reported by Proclus ${ }^{1}$ as saying that "the most extraordinary thing of his age was the lore of the Chaldaeans, who foretold not only events of public interest but even the lives and deaths of individuals'. One wonders slightly whether Theophrastus spoke with as much implicit faith as Proclus suggests. But the chief account is given by Diodorus, ii. 30 (perhaps from Hecataeus).

' Other nations despise the philosophy of Greece. It is so recent and so constantly changing. They have traditions which come from vast antiquity and never change. Notably the Chaldaeans have collected observations of the Stars through long ages, and teach how every event in the heavens has its meaning, as part of the eternal scheme of divine forethought. Especially the seven Wanderers, or Planets, are called by them Hermêneis, Interpreters : and among them the Interpreter in chief is Saturn. Their work is to interpret

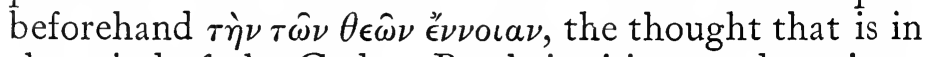
the mind of the Gods. By their risings and settings, and by the colours they assume, the Chaldaeans predict great winds and storms and waves of excessive heat, comets, and earthquakes, and in general all changes fraught with weal or woe not only to nations and regions of the world, but to kings and to ordinary men and women. Beneath the Seven are thirty Gods of Counsel, half below and half above the Earth; every ten days a messenger or Angel star passes from above below and another from below above. Above these gods are twelve Masters, who are the twelve signs of the Zodiac; and the planets pass through all 1 Proclus, In Timaeum, $285 \mathrm{~F}$. 
the Houses of these twelve in turn. The Chaldaeans have made prophecies for various kings, such as Alexander who conquered Darius, and Antigonus and Seleucus Nikator, and have always been right. And private persons who have consulted them consider their wisdom as marvellous and above human power.'

Astrology fell upon the Hellenistic mind as a new disease falls upon some remote island people. Every one was ready to receive the germ. The Epicureans, of course, held out, and so did Panaetius, the coolest head among the Stoics. But the Stoics as a whole gave way. They formed with good reason the leading school of philosophy, and it would have been a service to mankind if they had resisted. But they were already committed to a belief in the deity of the stars and to the doctrine of Heimarmenê, or Destiny. They believed in the pervading Pronoia, ${ }^{\mathbf{1}}$ or Forethought, of the divine mind, and in the $\Sigma v \mu \pi \alpha \dot{\theta} \theta \epsilon a \tau \hat{\omega} \nu$ ó $\lambda \omega \nu$ - the Sympathy of all Creation, ${ }^{2}$ so that whatever happens to any one part, however remote or insignificant, affects all the rest. It seemed only a natural and beautiful illustration of this Sympathy that the movements of the Stars should be bound up with the sufferings of man. They also appealed to the general belief in prophecy and divination. ${ }^{3}$ If a prophet

1 Chrysippus, II 87-95. Esse divinationem si di sint et providentia.

2 Cicero, De Nat. De. iii. I I, 28 ; especially De Divinatione, ii. I4, 34; 60,$124 ; 69,142$. ' Qua ex cognatione naturae et quasi concentu atque consensu, quam $\sigma v \mu \pi a ́ \theta \epsilon \iota a v$ Graeci appellant, convenire potest aut fissum iecoris cum lucello meo aut meus quaesticulus cum caelo, terra rerumque natura ?' asks the sceptic in the second of these passages.

${ }^{3}$ Chrysippus, 939-44. Vaticinatio probat fati necessitatem. 
can foretell that such and such an event will happen, then it is obviously fated to happen. Foreknowledge implies Predestination. This belief in prophecy was, in reality, a sort of appeal to fact and to common sense. People could produce then, as they can now, a large number of striking cases of second sight, presentiment, clairvoyance, actual prophecy and the like; ${ }^{\mathbf{1}}$ and it was more difficult then to test them.

The argument involved Stoicism with some questionable allies. Epicureans and sceptics of the Academy might well mock at the sight of a great man like Chrysippus or Posidonius resting an important part of his religion on the undetected frauds of a shady Levantine ' medium'. Still the Stoics could not but welcome the arrival of a system of prophecy and predestination which, however the incredulous might railat it, possessed at least great antiquity and great stores of learning, which was respectable, recondite, and in a way sublime.

In all the religious systems of later antiquity, if I mistake not, the Seven Planets play some lordly or terrifying part. The great Mithras Liturgy, unearthed by Dieterich from a magical papyrus in Paris, ${ }^{2}$ repeatedly confronts the worshipper with the seven vowels as names of 'the Seven Deathless Kosmokratores', or Lords of the Universe, and seems, under their influence, to go off into its 'Seven Maidens with heads of serpents, in white raiment', and its divers other Sevens.

1 Chrysippus, I214, I 200-6.

2 Eine Mitbrasliturgie, 1903. The MS. is 574 Supplément Grec de la Bibl. Nationale. The formulae of various religions were used as instruments of magic, as our own witches used the Lord's Prayer backwards. 
The various Hermetic and Mithraic communities, the Naassenes described by Hippolytus, ${ }^{1}$ and other Gnostic bodies, authors like Macrobius and even Cicero in his Somnium Scipionis, are full of the influence of the seven planets and of the longing to escape beyond them. For by some simple psychological law the stars which have inexorably pronounced our fate, and decreed, or at least registered the decree, that in spite of all striving we must needs tread their prescribed path; still more perhaps, the Stars who know in the midst of our laughter how that laughter will end, become inevitably powers of evil rather than good, beings malignant as well as pitiless, making life a vain thing. And Saturn, the chief of them, becomes the most malignant. To some of the Gnostics he becomes Jaldabaoth, the Lionheaded God, the evil Jehovah. ${ }^{2}$ The religion of later antiquity is overpoweringly absorbed in plans of escape from the prison of the seven planets.

In author after author, in one community after another, the subject recurs. And on the whole there is the same answer. Here on the earth we are the sport of Fate; nay, on the earth itself we are worse off still. We are beneath the Moon, and beneath the Moon there is not only Fate but something more unworthy and equally malignant, Chance-to say nothing of damp and the ills of earth and bad daemons. Above the Moon there is no chance, only Necessity; there is the will of the other six Kosmokratores, Rulers

1 Refutatio Omnium Haeresium, v. 7.

2 Bousset, p. 35I. The hostility of Zoroastrianism to the old Babylonian planet gods was doubtless at work also. Ib. pp. 37-46. 
of the Universe. But above them all there is an Eighth region-they call it simply the Ogdoas-the home of the ultimate God, ${ }^{1}$ whatever He is named, whose being was before the Kosmos. In this Sphere is true Being and Freedom. And more than freedom, there is the ultimate Union with God. For that spark of divine life which is man's soul is not merely, as some have said, an $\dot{\alpha} \pi o^{\prime} \rho \rho \iota \alpha \tau \hat{\omega} \nu$ ă $\sigma \tau \rho \omega \nu$, an effluence of the stars : it comes direct from the first and ultimate God, the Alpha and Omega, who is beyond the Planets. 'Though the Kosmokratores cast us to and fro like their slaves or dead chattels, in soul at least we are of equal birth with them. The Mithraic votary, when their wrathful and tremendous faces break in upon his vision, answers

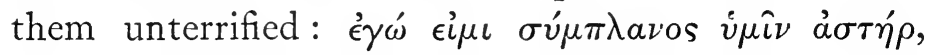
'I am your fellow Wanderer, your fellow Star.' The Orphic carried to the grave on his golden scroll the same boast: First, 'I am the child of Earth and of the starry Heaven;' then later, 'I too am become God.' 2 The Gnostic writings consist largely of charms to be uttered by the Soul to each of the Planets in turn, as it pursues its perilous path past all of them to its ultimate home.

That journey awaits us after death; but in the meantime? In the meantime there are initiations, sacraments, mystic ways of communion with God. To see God face to face is, to the ordinary unprepared man, sheer death. But to see Him after due purification, to be led to Him along the true Way by an

1 Or, in some Gnostic systems, of the Mother.

${ }^{2}$ Harrison, Prolegomena, Appendix on the Orphic tablets. 
initiating Priest, is the ultimate blessing of human life. It is to die and be born again. There were regular official initiations. We have one in the MithrasLiturgy, more than one in the Corpus Hermeticum. Apuleius ${ }^{1}$ tells us at some length, though in guarded language, how he was initiated to Isis and became ' her image'. After much fasting, clad in holy garments and led by the High Priest, he crossed the threshold of Death and passed through all the Elements. The Sun shone upon him at midnight, and he saw the Gods of Heaven and of Hades. In the morning he was clad in the Robe of Heaven, set up on a pedestal in front of the Goddess and worshipped by the congregation as a God. He had been made one with Osiris or Horus or whatever name it pleased that Sun-God to be called. Apuleius does not reveal it.

There were also, of course, the irregular personal initiations and visions of god vouchsafed to persons of special prophetic powers. St. Paul, we may remember, knew personally a man who had actually been snatched up into the Third Heaven, and another who was similarly rapt into Paradise, where he heard unspeakable words ; ${ }^{2}$ whether in the body or not, the apostle leaves undecided. He himself on the road to Damascus had seen the Christ in glory, not after the flesh. The philosopher Plotinus, so his disciple tells

\section{Ap. Metamorphoses, xi.}

22 Cor. xii. 2 and 3 (he may be referring in veiled language to himself); Gal.i. I2 ff.; Acts ix. I-22. On the difference of tone and fidelity between the Epistles and the Acts see the interesting remarks of Prof. P. Gardner, $\mathcal{T}$ be Religious Experience of St. Paul, pp. $5 \mathrm{ff}$. 
us, was united with God in trance four times in five years. ${ }^{3}$

We seem to have travelled far from the simplicity of early Greek religion. Yet most of the movement has been, and perhaps not quite unconsciously, a reaction under Oriental and barbarous influences towards the most primitive pre-Hellenic cults. The union of man with God came regularly through Ekstasis-the soul must get clear of its body-and Enthousiasmos-the God must enter and dwell inside the worshipper. But the means to this union, while sometimes allegorized and spiritualized to the last degree, are sometimes of the most primitive sort. The vagaries of religious emotion are apt to reach very low as well as very high in the scale of human nature. Certainly the primitive Thracian savages, who drank themselves mad with the hot blood of their God-beast, would have been quite at home in some of these

1 Porphyry, Vita Plotini, 23. "We have explained that he was good and gentle, mild and merciful; we who lived with him could feel it. We have said that he was vigilant and pure of soul, and always striving towards the Divine, which with all his soul he loved. ... And thus it happened to this extraordinary man, constantly lifting himself up towards the first and transcendent God by thought and the ways explained by Plato in the Symposium, that there actually came a vision of that God who is without shape or form, established above the understanding and all the intelligible world. To whom I, Porphyry, being now in my sixty-eighth year, profess that I once drew near and was made one with him. At any rate he appeared to Plotinus " a goal close at hand". For his whole end and goal was to be made One and draw near to the supreme God. And he attained that goal four times, I think, while I was living with him-not potentially but in actuality, though an actuality which surpasses speech.' 
rituals, though in others they would have been put off with some substitute for the actual blood. The primitive priestesses who waited in a bridal chamber for the Divine Bridegroom, even the Cretan Kourêtes with their Zeus Kourês ${ }^{1}$ and those strange hierophants of the 'Men's House' whose enigmatic message is written on the rocks of 'Thera, would have found rites very like their own reblossoming on earth after the fall of Hellenism. 'Prepare thyself as a bride to receive her bridegroom,' says Markos the Gnostic, ' 'that thou mayst be what I am and I what thou art.' 'I in thee, and thou in me!' is the ecstatic cry of one of the Hermes liturgies. Before that the prayer has been 'Enter into me as a babe into the womb of a woman'. ${ }^{3}$

In almost all the liturgies that $I$ have read need is felt for a mediator between the seeker after God and his goal. Mithras himself was a Mesîtês, a Mediator, between Ormuzd and Ahriman, but the ordinary mediator is more like an interpreter or an adept with inner knowledge which he reveals to the outsider. The circumstances out of which these systems grew have left their mark on the new gods themselves. As usual, the social structure of the worshippers is reflected in their objects of worship. When the Chaldaeans came to Cos, when the Thracians in the Piraeus set up their national worship of Bendis, when the Egyptians in the

1 G.I.G., vol. xii, fasc. 3 ; and Bethe in Rhein. Mus., N. F., xlii, $438-475$.

2 Irenaeus, i. 13.3.

3 Bousset, chap. vii ; Reitzenstein, Mysterienreligionen, pp. 20 ff., with excursus; Poimandres, $226 \mathrm{ff}$. D Dieterich, Mitbrasliturgie, pp. I2I ff. 
same port founded their society for the Egyptian ritual of Isis, when the Jews at Assuan in the fifth century в.c. established their own temple, in each case there would come proselytes to whom the truth must be explained and interpreted, sometimes perhaps softened. And in each case there is behind the particular priest or initiator there present some greater authority in the land he comes from. Behind any explanation that can be made in the Piracus, there is a deeper and higher explanation known only to the great master in Jerusalem, in Egypt, in Babylon, or perhaps in some unexplored and ever-receding region of the east. This series of revelations, one behind the other, is a characteristic of all these mixed Graeco-Oriental religions.

Most of the Hermetic treatises are put in the form of initiations or lessons revealed by a 'father' to a ' son ', by Ptah to Hermes, by Hermes to 'Thoth or Asclepios, and by one of them to us. It was an ancient formula, a natural vehicle for traditional wisdom in Egypt, where the young priest became regularly the 'son' of the old priest. It is a form that we find in Greece itself as early as Euripides, whose Melanippe says of her cosmological doctrines,

\section{'It is not my word but my Mother's word.' 1}

It was doubtless the language of the old Medicine-Man to his disciple. In one fine liturgy Thoth wrestles with Hermes in agony of spirit, till Hermes is forced to reveal to him the path to union with God which he himself has trodden before. At the end of the 
Mithras liturgy the devotee who has passed through the mystic ordeals and seen his god face to face, is told : 'After this you can show the way to others.'

But this leads us to the second great division of our subject. We turn from the phenomena of the sky to those of the soul.

If what I have written elsewhere is right, one of the greatest works of the Hellenic spirit, and especially of fifth-century Athens, was to insist on what seems to us such a commonplace truism, the difference between Man and God. Sophrosynê in religion was the message of the classical age. But the ages before and after had no belief in such a lesson. The old Medicine-Man was perhaps himself the first $\mathcal{T}$ beos. At any rate the primaeval kings and queens were treated as divine. ${ }^{1}$ Just for a few great generations it would seem humanity rose to a sufficient height of self-criticism and self-restraint to reject these dreams of self-abasement or megalomania. But the effort was too great for the average world; and in a later age nearly all the kings and rulers -all people in fact who can command an adequate number of flatterers-become divine beings again. Let us consider how it came about.

First there was the explicit recognition by the soberest philosophers of the divine element in man's soul. ${ }^{2}$ Aristotle himself built an altar to Plato. He did

1 R.G.E. ${ }^{2}$, pp. $155-60$. I do not touch on the political side of this apotheosis of Hellenistic kings; it is well brought out in Ferguson's Hellenistic Athens, e.g. p. 108 f., also p. II f. and note.

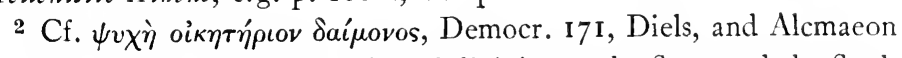
is said by Cicero to have attributed divinity to the Stars and the Soul. 
nothing superstitious; he did not call Plato a god, but we can see from his beautiful elegy to Eudemus, that he naturally and easily used language of worship which would seem a little strange to us. It is the same emotion-a noble and just emotion on the wholewhich led the philosophic schools to treat their founders as 'heroes', and which has peopled most of Europe and Asia with the memories and the worship of saints. But we should remember that only a rare mind will make its divine man of such material as Plato. The common way to dazzle men's eyes is a more brutal and obvious one.

To people who were at all accustomed to the conception of a God-Man it was difficult not to feel that the conception was realized in Alexander. His tremendous power, his brilliant personality, his achievements beggaring the fables of the poets, put people in the right mind for worship. Then came the fact that the kings whom he conquered were, as a matter of fact, mostly regarded by their subjects as divine beings. ${ }^{1}$ It was easy, it was almost inevitable, for those who worshipped the 'God' 2 Darius to feel that it was no man but a greater god who had overthrown Darius. The incense which had been burned before those conquered gods was naturally offered to their conqueror. He did not refuse it. It was not good

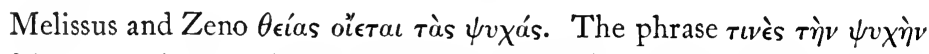

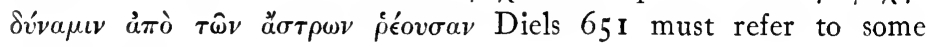
Gnostic sect.

1 See for instance Frazer, Golden Bough ${ }^{3}$, part I, i. 417-19.

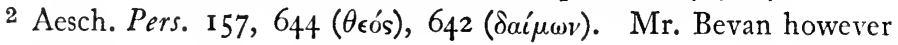
suspects that Aeschylus misunderstood his Persian sources: see his article on 'Deification' in Hastings' Dictionary of Religion. 
policy to do so, and self-depreciation is not apt to be one of the weaknesses of the born ruler. ${ }^{1}$ But besides all this, if you are to judge a God by his fruits, what God could produce better credentials? Men had often seen Zeus defied with impunity; they had seen faithful servants of Apollo come to bad ends. But those who defied Alexander, however great they might be, always rued their defiance, and those who were faithful to him always received their reward. With his successors the worship became more official. Seleucus, Ptolemaeus, Antigonus, Demetrius, all in different degrees and different styles are deified by the acclamations of adoring subjects. Ptolemy Philadelphus seems to have been the first to claim definite divine honours during his own life. On the death of his wife in $27 \mathrm{I}$ he proclaimed her deity and his own as well in the worship of the Theoi Adelphoi, the 'Gods Brethren'. Of course there was flattery in all this, ordinary selfinterested lying flattery, and its inevitable accompaniment, megalomania. Any reading of the personal history of the Ptolemies, the Seleucidae or the Caesars shows it. But that is not the whole explanation.

One of the characteristics of the period of the Diadochi is the accumulation of capital and military force in the hands of individuals. The Ptolemies and

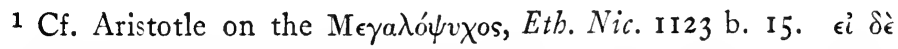

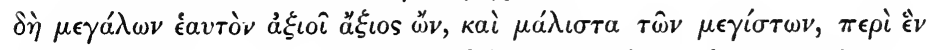

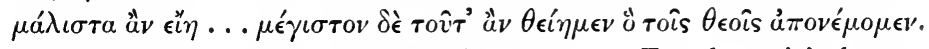
But these kings clearly transgressed the mean. For the satirical comments of various public men in Athens, see Ed. Meyer, Kleine Scbriften, $301 \mathrm{ff}$., 330. 
Seleucidae had at any moment at their disposal powers very much greater than any Pericles or Nicias or Lysander. ${ }^{1}$ The folk of the small cities of the Aegean hinterlands must have felt towards these great strangers almost as poor Indian peasants in time of flood and famine feel towards an English official. There were men now on earth who could do the things that had hitherto been beyond the power of man. Were several cities thrown down by earthquake; here was one who by his nod could build them again. Famines had always occurred and been mostly incurable. Here was one who could without effort allay a famine. Provinces were harried and wasted by habitual wars: the eventual conqueror had destroyed whole provinces in making the wars; now, as he had destroyed, he could also save. 'What do you mean by a god,' the simple man might say, 'if these men are not gods? The only difference is that these gods are visible, and the old gods no man has seen.'

The titles assumed by all the divine kings tell the story clearly. Antiochus Epiphanês-' the god made manifest'; Ptolemaios Euergetês, Ptolemaios Sôtêr. Occasionally we have a Keraunos or a Nikator, a ' 'Thunderbolt' or a 'God of Mana', but mostly it is Sôtêr, Euergetês and Epiphanês, the Saviour, the Benefactor, the God made manifest, in constant alternation. In the honorific inscriptions and in the writings of the learned, philanthropy $(\phi \iota \lambda a \nu \theta \rho \omega \pi i a)$ is by far the most prominent characteristic of the God upon earth. Was it that people really felt that to

1 Lysander too had altars raised to him by some Asiatic cities. 
save or benefit mankind was a more godlike thing than to blast and destroy them? Philosophers have generally said that, and the vulgar pretended to believe them. It was at least politic, when ministering to the halfinsane pride of one of these princes, to remind him of his mercy rather than of his wrath.

Wendland in his brilliant book, Hellenistiscbrömische Kultur, calls attention to an inscription of the year I 96 B.C. in honour of the young Ptolemaios Epiphanês, who was made manifest at the age of twelve years. ${ }^{1}$ It is a typical document of GraecoEgyptian king-worship :

'In the reign of the young king by inheritance from his Father, Lord of the Diadems, great in glory, pacificator of Egypt and pious towards the gods, superior over his adversaries, Restorer of the life of man, Lord of the Periods of Thirty Years, like Hephaistos the Great, King like the Sun, the Great King of the Upper and Lower Lands; offspring of the Gods of the Love of the Father, whom Hephaistos has approved, to whom the Sun has given Victory; living image of Zeus ; Son of the Sun, Ptolemaios the everliving, beloved by Phtha; in the ninth year of Aëtos son of Aëtos, Priest of Alexander and the Gods Saviours and the Gods Brethren and the Gods Benefactors and the Gods of the Love of the Father and the God Manifest for whom thanks be given:'

The Priests who came to his coronation ceremony at Memphis proclaim :

'Seeing that King Ptolemaios ever-living, beloved

1 Dittenberger, Inscr. Orientis Graeci, 90; Wendland, Hellenistisch-römische Kultur, 1907, pp. 7 f. and notes. 
of Phtha, God Manifest for whom Thanks be given, born of King Ptolemaios and Queen Arsinoe, the Gods of the Love of the Father, has done many benefactions to the Temples and those in them and all those beneath his rule, being from the beginning God born of God and Goddess, like Horus son of Isis and Osiris, who came to the help of his father Osiris, (and?) in his benevolent disposition towards the Gods has consecrated to the temples revenues of silver and of corn, and has undergone many expenses in order to lead Egypt into the sunlight and give peace to the Temples, and has with all his powers shown love of mankind.'

When the people of Lycopolis revolted, we hear :

${ }^{6}$ in a short time he took the city by storm and slew all the Impious who dwelt in it, even as Hermes and Horus, son of Isis and Osiris, conquered those who of old revolted in the same regions ... in return for which the Gods have granted him Health Victory Power and all other good things, the Kingdom remaining to him and his sons for time everlasting.' ${ }^{1}$

The conclusion which the Priests draw from these

1 Several of the phrases are interesting. The last gift of the heavenly gods to this Theos is the old gift of Mana. In Hesiod it was Kápros $\tau \epsilon \operatorname{Bi\eta } \tau \epsilon$, the two ministers who are never away from the King Zeus. In Aeschylus it was Kratos and Bia who subdue Prometheus. In Tyrtaeus it was Ník $\eta$ каı Kápтos. In other inscriptions of the Ptolemaic

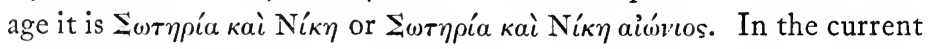
Christian liturgies it is 'the Kingdom, the Power, and the Glory'. R.G.E. ${ }^{2}$, p. $155 \mathrm{n}$. The new conception, as always, is rooted in the old. 'The Gods Saviours, Brethren, \&c., are of course Ptolemy Soter, Ptolemy Philadelphus, \&c., and their Queens.' The phrases єikìv

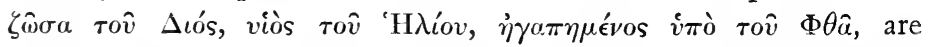
characteristic of the religious language of this period. Cf. also Col.

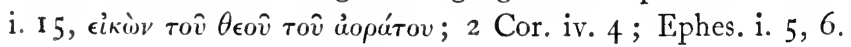


facts is that the young king's titles and honours are insufficient and should be increased. It is a typical and terribly un-Hellenic document of the Hellenistic God-man in his appearance as King.

Now the early successors of Alexander mostly professed themselves members of the Stoic school, and in the mouth of a Stoic this doctrine of the potential divinity of man was an inspiring one. To them virtue was the really divine thing in man: and the most divine kind of virtue was that of helping humanity. To love and help humanity is, according to Stoic doctrine, the work and the very essence of God. If you take away Pronoia from God, says Chrysippus, ${ }^{1}$ it is like taking away light and heat from fire. This doctrine is magnificently expressed by Pliny in a phrase that is probably translated from Posidonius: ' God is the helping of man by man; and that is the way to eternal glory.' 2

The conception took root in the minds of many Romans. A great Roman governor often had the chance of thus helping humanity on a vast scale, and liked to think that such a life opened the way to heaven. ' One should conceive,' says Cicero (I usc. i. 32), ' the gods as like men who feel themselves born for the work of helping, defending, and saving humanity. Hercules has passed into the number of the gods. He would

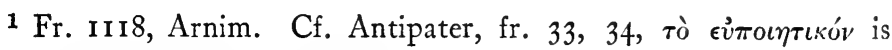
part of the definition of Deity.

2 Plin., Nat. Hist. ii. 7, 18. Deus est mortali iuvare mortalem et haec ad aeternam gloriam via. Cf. also the striking passages from Cicero and others in Wendland, p. 85, n. 2. 
never have so passed if he had not built up that road for himself while he was among mankind.'

I have been using some rather late authors, though the ideas seem largely to come from Posidonius. ${ }^{1}$ But before Posidonius the sort of fact on which we have been dwelling had had its influence on religious speculation. When Alexander made his conquering journey to India and afterwards was made a god, it was impossible not to reflect that almost exactly the same story was related in myth about Dionysus. Dionysus had started from India and travelled in the other direction: that was the only difference. A flood of light seemed to be thrown on all the traditional mythology, which, of course, had always been a puzzle to thoughtful men. It was impossible to believe it as it stood, and yet hard-in an age which had not the conception of any science of mythology-to think it was all a mass of falsehood, and the great Homer and Hesiod no better than liars. But the generation which witnessed the official deification of the various Seleucidae and Ptolemies seemed suddenly to see light. The traditional gods, from Heracles and Dionysus up to Zeus and Cronos and even Ouranos, were simply oldworld rulers and benefactors of mankind, who had, by their own insistence or the gratitude of their subjects, been transferred to the ranks of heaven. For that is the exact meaning of making them divine: they are

1 The Stoic philosopher, teaching at Rhodes, c. I00 B.c. A man of immense knowledge and strong religious emotions, he moved the Stoa in the direction of Oriental mysticism. See Schwartz's sketch in Cbaracterköpfe 2 , pp. 89-98. Also Norden's Commentary on Aeneid vi. 
classed among the true immortals, the Sun and Moon and Stars and Corn and Wine, and the everlasting elements.

The philosophic romance of Euhemerus, published early in the third century B.c., had instantaneous success and enormous influence. ${ }^{1}$ It was one of the first Greek books translated into Latin, and became long afterwards a favourite weapon of the Christian fathers in their polemics against polytheism. 'Euhemerism' was, on the face of it, a very brilliant theory; and it had, as we have noticed, a special appeal for the Romans.

Yet, if such a conception might please the leisure of a statesman, it could hardly satisfy the serious thought of a philosopher or a religious man. If man's soul really holds a fragment of God and is itself a divine being, its godhead cannot depend on the possession of great riches and armies and organized subordinates. If ' the helping of man by man is God', the help in question cannot be material help. The religion which ends in deifying only kings and millionaires may be vulgarly popular but is self-condemned.

As a matter of fact the general tendency of Greek philosophy after Plato, with some illustrious exceptions, especially among the Romanizing Stoics, was away from the outer world towards the world of the soul. We find in the religious writings of this period that the real Saviour of men is not he who protects them against earthquake and famine, but he who in some sense saves their souls. He reveals to them the Gnôsis $T$ beou, the

1 Jacoby in Pauly-Wissowa's Realencyclopädic, vi. 954. It was called 'I $\epsilon \rho \grave{a}$ 'A $v a \gamma \rho a \phi \eta$ '. 
Knowledge of God. 'The 'knowledge' in question is not a mere intellectual knowledge. It is a complete union, a merging of beings. And, as we have always to keep reminding our cold modern intelligence, he who has ' known' God is himself thereby deified. He is the Image of God, the Son of God, in a sense he is God. The stratum of ideas described in the first of the studies will explain the ease with which transition took place. The worshipper of Bacchos became Bacchos simply enough, because in reality the God Bacchos was originally only the projection of the human Bacchoi. And in the Hellenistic age the notion of these secondary mediating gods was made easier by the analogy of the human interpreters. Of course we have abundant instances of actual preachers and miracle-workers who on their own authority posed, and were accepted, as gods. The adventure of Paul and Barnabas at Lystra ${ }^{1}$ shows how easily such things could happen. But as a rule, I suspect, the most zealous priest or preacher preferred to have his God in the background. He preaches, he heals the sick and casts out devils, not in his own name but in the name of One who sent him. This actual present priest who initiates you or me is himself already an Image of God; but above him there are greater and wiser priests, above them others, and above all there is the one eternal Divine Mediator, who being in perfec-

1 Acts xiv. I2. They called Barnabas Zeus and Paul Hermes,

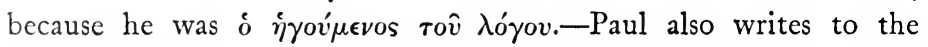
Galatians (iv. I4): "Ye received me as a messenger of God, as Jesus Cbrist.' 
tion both man and God can alone fully reveal God to man, and lead man's soul up the heavenly path, beyond Change and Fate and the Houses of the Seven Rulers, to its ultimate peace. I have seen somewhere a Gnostic or early Christian emblem which indicates this doctrine. Some Shepherd or Saviour stands, his feet on the earth, his head towering above the planets, lifting his follower in his outstretched arms.

The Gnostics are still commonly thought of as a body of Christian heretics. In reality there were Gnostic sects scattered over the Hellenistic world before Christianity as well as after. They must have been established in Antioch and probably in Tarsus well before the days of Paul or Apollos. Their Saviour, like the Jewish Messiah, was established in men's minds before the Saviour of the Christians. 'If we look close,' says Professor Bousset, ' the result emerges with great clearness, that the figure of the Redeemer as such did not wait for Christianity to force its way into the religion of Gnôsis, but was already present there under various forms.' ${ }^{1} \mathrm{He}$ occurs notably in two preChristian documents, discovered by the keen analysis and profound learning of Dr. Reitzenstein: the Poimandres revelation printed in the Corpus Hermeticum, and the sermon of the Naassenes in Hippolytus, Refutatio Omnium Haeresium, which is combined with Attis-worship. ${ }^{2}$ The violent anti-Jewish bias of most of the sects-they speak of 'the accursed God of the Jews' and identify him with Saturn and the Devil-

1 Bousset, p. 238.

${ }^{2}$ Hippolytus, I34, 90 ff., text in Reitzenstein's Poimandres, pp. 83-98. 
points on the whole to pre-Christian conditions; and a completely non-Christian standpoint is still visible in the Mandaean and Manichean systems.

Their Redeemer is descended by a fairly clear genealogy from the 'Tritos Sôtêr' of early Greece, contaminated with similar figures, like Attis and Adonis from Asia Minor, Osiris from Egypt, and the special Jewish conception of the Messiah of the Chosen people. He has various names, which the name of Jesus or 'Christos ', ' the Anointed,' tends gradually to supersede. Above all he is, in some sense, Man, or ' the Second Man' or ' the Son of Man'. The origin of this phrase needs a word of explanation. Since the ultimate unseen God, spirit though $\mathrm{He}$ is, made Man in His image, since holy men (and divine kings) are images of God, it follows that He is Himself Man. He is the real, the ultimate, the perfect and eternal Man, of whom all bodily men are feeble copies. He is also the Father; the Saviour is his Son, 'the Image of the Father,' ' the Second Man,' ' the Son of Man.' 'The method in which he performs his mystery of Redemption varies. It is haunted by the memory of the old Suffering and Dying God, of whom we spoke in the first of these studies. It is vividly affected by the ideal 'Righteous Man' of Plato, who 'shall be scourged, tortured, bound, his eyes burnt out, and at last, after suffering every evil, shall be impaled or crucified '.

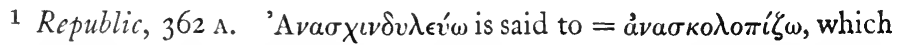
is used both for 'impale' and 'crucify'. The two were alternative forms of the most slavish and cruel capital punishment, impalement being mainly Persian, crucifixion Roman. 
But in the main he descends, of his free will or by the eternal purpose of the Father, from Heaven through the spheres of all the Archontes or Kosmokratores, the planets, to save mankind, or sometimes to save the fallen Virgin, the Soul, Wisdom, or 'the Pearl' 1. The Archontes let him pass because he is disguised; they do not know him (cf. I Cor. ii. 7 ff.). When his work is done he ascends to Heaven to sit by the side of the Father in glory; he conquers the Archontes, leads them captive in his triumph, strips them of their armour (Col. ii. I 5 ; cf. the previous verse), sometimes even crucifies them for ever in their places in the sky. ${ }^{2}$ The epistles to the Colossians and the Ephesians are much influenced by these doctrines. Paul himself constantly uses the language of them, but in the main we find him discouraging the excesses of superstition, reforming, ignoring, rejecting. His Jewish blood was perhaps enough to keep him to strict monotheism. Though he admits Angels and Archontes, Principalities and Powers, he scorns the Elements and he seems deliberately to reverse the doctrine of the first and second Man. ${ }^{3} \mathrm{He}$ says nothing about the Trinity of Divine Beings that was usual in Gnosticism, nothing about the Divine Mother. His mind, for all its vehement mysticism and enthusiasm, has something of that clean antiseptic quality that makes the works of such early Christians as Minucius Felix and Diognetus so infinitely refreshing.

1 See The Hymn of the Soul, attributed to the Gnostic Bardesanes, edited by A. A. Bevan, Cambridge, I897.

2 Bousset cites Acta Archelai 8, and Epiphanius, Haeres. 66. 32.

3 Gal. iv. 9; I Cor. xv. 2 I f., 47 ; Rom. v. I2-I8. 
He is certainly one of the great figures in Greek literature, but his system lies outside the subject of this essay. We are concerned only with those last manifestations of Hellenistic religion which probably formed the background of his philosophy. It is strange to reflect, and it shows what queer stuff we humans are made of, that it was these obscure congregations, superstitious and over-emotional, mostly ignorant and often the prey of charlatans, who held the main road of advance towards the greatest religion of the western world.

I have tried to sketch in outline the main forms of belief to which Hellenistic philosophy moved or drifted. Let me dwell for a few pages more upon the characteristic method by which it reached them. It may be summed up in one word, Allegory. All Hellenistic philosophy from the first Stoics onwards is permeated by allegory. It is applied to Homer, to the religious traditions, to the ancient rituals, to the whole world. To Sallustius after the end of our period the whole material world is only a great myth, a thing whose value lies not in itself but in the spiritual meaning which it hides and reveals. To Cleanthes at the beginning of it the Universe was a mystic pageant, in which the immortal stars were the dancers and the Sun the priestly torch-bearer. ${ }^{1}$ Chrysippus reduced the Homeric gods to physical or ethical principles; and Crates, the great critic, applied allegory in detail to

1 Cleanthes, 538, Arnim; Diels, p. 592, 30. Cf. Philolaus, Diels pp. $336 \mathrm{f}$. 
his interpretation of the all-wise poet. ${ }^{1}$ We possess two small but complete treatises which illustrate well the results of this tendency, Cornutus $\pi \epsilon \rho i \theta \epsilon \hat{\omega} \nu$ and the Homeric Allegories of Heraclitus, a brilliant little work of the first century в.c. I will not dwell upon details: they are abundantly accessible and individually often ridiculous. A by-product of the same activity is the mystic treatment of language: a certain Titan in Hesiod is named Koios. Why? Because the Titans are the elements and one of them

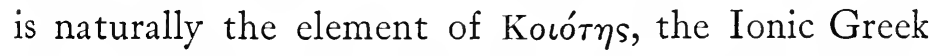
for 'Quality'. 'The Egyptian Isis is derived from the root of the Greek $\epsilon i \delta$ '́val, Knowledge, and the Egyptian Osiris from the Greek órıs and ipós ('holy' and 'sacred', or perhaps more exactly 'lawful' and ' $t a b u^{\prime}$ ). Is this totally absurd ? I think not. If all human language is, as most of these thinkers believed, a divine institution, a cup filled to the brim with divine meaning, so that by reflecting deeply upon a word a pious philosopher can reach the secret that it holds, then there is no difficulty whatever in supposing that the special secret held by an Egyptian word may be found in Greek, or the secret of a Greek word in Babylonian. Language is One. The Gods who made all these languages equally could use them all, and wind them all intricately in and out, for the building up of their divine enigma.

We must make a certain effort of imagination to understand this method of allegory. It is not the

1 See especially the interpretation of Nestor's Cup, Athenaeus, pp. 489 c. ff. 
frigid thing that it seems to us. In the first place, we should remember that, as applied to the ancient literature and religious ritual, allegory was at least a vera causa-it was a phenomenon which actually existed. Heraclitus of Ephesus is an obvious instance. $\mathrm{He}$ deliberately expressed himself in language which should not be understood of the vulgar, and which bore a hidden meaning to his disciples. Pythagoras did the same. The prophets and religious writers must have done so to an even greater extent. ${ }^{1}$ And we know enough of the history of ritual to be sure that a great deal of it is definitely allegorical. 'The Hellenistic Age did not wantonly invent the theory of allegory.

And secondly, we must remember what states of mind tend especially to produce this kind of belief. They are not contemptible states of mind. It needs only a strong idealism with which the facts of experience clash, and allegory follows almost of necessity. The facts cannot be accepted as they are. 'They must needs be explained as meaning something different.

Take an earnest Stoic or Platonist, a man of fervid mind, who is possessed by the ideals of his philosophy and at the same time feels his heart thrilled by the beauty of the old poetry. What is he to do? On one side he can find Zoilus, or Plato himself, or the Cynic preachers, condemning Homer and the poets without remorse, as teachers of foolishness. He can treat poetry as the English Puritans treated the stage. But is that

${ }^{1}$ I may refer to the learned and interesting remarks on the Esoteric Style in Prof. Margoliouth's edition of Aristotle's Poetics. It is not, of course, the same as Allegory. 
a satisfactory solution? Remember that these generations were trained habitually to give great weight to the voice of their inner consciousness, and the inner consciousness of a sensitive man cries out that any such solution is false: that Homer is not a liar, but noble and great, as our fathers have always taught us. On the other side comes Heraclitus the allegorist. 'If Homer used no allegories he committed all impieties.' On this theory the words can be allowed to possess all their old beauty and magic, but an inner meaning is added quite different from that which they bear on the surface. It may, very likely, be a duller and less poetic meaning; but I am not sure that the verses will not gain by the mere process of brooding study fully as much as they lose by the ultimate badness of the interpretation. Anyhow, that was the road followed. The men of whom I speak were not likely to give up any experience that seemed to make the world more godlike or to feed their spiritual and emotional cravings. They left that to the barefooted cynics. They craved poetry and they craved philosophy; if the two spoke like enemies, their words must needs be explained away by one who loved both.

The same process was applied to the world itself. Something like it is habitually applied by the religious idealists of all ages. A fundamental doctrine of Stoicism and most of the idealist creeds was the perfection and utter blessedness of the world, and the absolute fulfilment of the purpose of God. Now obviously this belief was not based on experience. The poor world, to do it justice amid all its misdoings, has 
never lent itself to any such barefaced deception as that. No doubt it shrieked against the doctrine then, as loud as it has always shrieked, so that even a Posidonian or a Neo-Platonist, his ears straining for the music of the spheres, was sometimes forced to listen. And what was his answer? It is repeated in all the literature of these sects. "Our human experience is so small : the things of the earth may be bad and more than bad, but, ah! if you only went beyond the Moon!' That is where the true Kosmos begins. And, of course, if we did ever go there, we all know they would say it began beyond the Sun. Idealism of a certain type will have its way; if hard life produces an ounce or a pound or a million tons of fact in the scale against it, it merely dreams of infinite millions in its own scale, and the enemy is outweighed and smothered. I do not wish to mock at these Posidonian Stoics and Hermetics and Gnostics and Neo-Platonists. They loved goodness, and their faith is strong and even terrible. One feels rather inclined to bow down before their altars and cry: Magna est Delusio et praevalebit.

Yet on the whole one rises from these books with the impression that all this allegory and mysticism is bad for men. It may make the emotions sensitive, it certainly weakens the understanding. And, of course, in this paper I have left out of account many of the grosser forms of superstition. In any consideration of the balance, they should not be forgotten.

If a reader of Proclus and the Corpus Hermeticum wants relief, he will find it, perhaps, best in the writings 
of a gentle old Epicurean who lived at Oenoanda in Cappadocia about A.D. 200. His name was Diogenes. ${ }^{1}$ His works are preserved, in a fragmentary state, not on papyrus or parchment, but on the wall of a large portico where he engraved them for passers-by to read. He lived in a world of superstition and foolish terror, and he wrote up the great doctrines of Epicurus for the saving of mankind.

'Being brought by age to the sunset of my life, and expecting at any moment to take my departure from the world with a glad song for the fullness of my happiness, I have resolved, lest I be taken too soon, to give help to those of good temperament. If one person or two or three or four, or any small number you choose, were in distress, and I were summoned out to help one after another, I would do all in my power to give the best counsel to each. But now, as I have said, the most of men lie sick, as it were of a pestilence, in their false beliefs about the world, and the tale of them increases; for by imitation they take the disease from one another, like sheep. And further it is only just to bring help to those who shall come after us-for they too are ours, though they be yet unborn; and love for man commands us also to help strangers who may pass by. Since therefore the good message of the Book has gone forth to many, I have resolved to make use of this wall and to set forth in public the medicine of the healing of mankind.'

The people of his time and neighbourhood seem to have fancied that the old man must have some bad motive. They understood mysteries and redemptions and revelations. They understood magic and curses.

1 Published in the Teubner series by William, 1907 . 
But they were puzzled, apparently, by this simple message, which only told them to use their reason, their courage and their sympathy, and not to be afraid of death or of angry gods. The doctrine was condensed into four sentences of a concentrated eloquence that make a translator despair : ${ }^{1}$ 'Nothing to fear in God: Nothing to feel in Death: Good can be attained: Evil can be endured.'

Of course the doctrines of this good old man do not represent the whole truth. To be guided by one's aversions is always a sign of weakness or defeat; and it is as much a failure of nerve to reject blindly for fear of being a fool, as to believe blindly for fear of missing some emotional stimulus.

There is no royal road in these matters. I confess it seems strange to me as I write here, to reflect that at this moment many of my friends and most of my fellow creatures are, as far as one can judge, quite confident that they possess supernatural knowledge. As a rule, each individual belongs to some body which has received in writing the results of a divine revelation. I cannot share in any such feeling. YThe uncharted surrounds us on every side and we must needs have some relation towards it, a relation which will depend on the general discipline of a man's mind and the bias of his whole character. As far as knowledge and conscious reason will go, we should follow resolutely

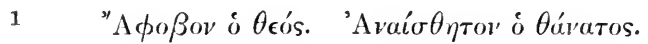

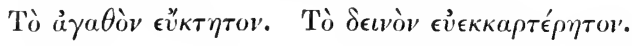

I regret to say that I cannot track this Epicurean 'tetractys' to its source. 
their austere guidance. When they cease, as cease they must, we must use as best we can those fainter powers of apprehension and surmise and sensitiveness by which, after all, most high truth has been reached as well as most high art and poetry: careful always really to seek for truth and not for our own emotional satisfaction, careful not to neglect the real needs of men and women through basing our life on dreams; and remembering above all to walk gently in a world where the lights are dim and the very stars wander.

\section{Bibliographical Note}

It is not my purpose to make any thing like a systematic bibliography, but a few recommendations may be useful to some students who approach this subject, as I have done, from the side of classical Greek.

For Greek Philosophy I have used besides Plato and Aristotle, Diogenes Laertius and Philodemus, Diels, Fragmente der I'orsokratiker; Diels, Doxographi Graeci; von Arnim, Stoicorum Veterum Fragmenta; Usener, Epicurea; also the old Fragmenta Philosophorum of Mullach.

For later Paganism and Gnosticism, Reitzenstein, Poimandres; Reitzenstein, Die Hellenistischen Mysterienreligionen; Dieterich, Eine Mitbrasliturgie (also Abraxas, Nekyia, Muttererde, \&c.); P. Wendland, Hellenistisch-Römische Kultur; Cumont, Textes et Monuments relatifs aux Mystères de Mithra (also The Mysteries of Mitbra, Chicago, 1903), and Les Religions Orientales dans l'Empire Romain; Seeck, Untergang der antiken Welt, vol. iii; Philo, de Vita Contemplativ'a, Conybeare ; Gruppe, Griechische Religion und Mytbologie, pp. I4581676; Bousset, Hauptprobleme der Gnosis, 1907, with good bibliography in the introduction; articles by E. Bevan in the Quarterly Review, No. 424 (June 1910), and the Hibbert Fournal, xi. I (October 1912). Dokumente der Gnosis, by W. Schultz. (Jena, I910), gives a highly subjective translation and reconstruction of most of the Gnostic documents: the Corpus Hermeticum is translated into English by G. R. S. Meade, Thrice Greatest Hermes, 1906. 
For Jewish thought before the Christian era Dr. Charles's Testaments of the Twelve Patriarchs; also the same writer's Book of Enoch, and the Religionsgescbicbtliche Erklärung des Neuen Testaments by Carl Clemen, Giessen, I909.

Of Christian writers apart from the New Testament those that come most into account are Hippolytus (†A.D. 250), Refutatio Omnium Haeresium, Epiphanius (367-403), Panarion, and Irenaeus († A.D. 202), Contra Hacreses, i, ii. For a simple introduction to the problems presented by the New Testament literature I would venture to recommend Prof. Bacon's New Testament, in the Home University Library, and Dr. Estlin Carpenter's First Three Gospels. In such a vast literature I dare not make any further recommendations, but for a general introduction to the History of Religions with a good and brief bibliography I would refer the reader to Salomon Reinach's Orpheus (Paris, I909; English translation the same year), a book of wide learning and vigorous thought. 
IV

\section{THE LAST PRO'TEST}





\section{IV \\ THE LAST PROTEST}

In the last essay we have followed Greek popular religion to the very threshold of Christianity, till we found not only a soil ready for the seed of Christian metaphysic, but a large number of the plants already in full and exubcrant growth. A complete history of Greek religion ought, without doubt, to include at least the rise of Christianity and the growth of the Orthodox Church, but, of course, the present series of studies does not aim at completeness. We will take the Christian theology for granted as we took the classical Greek philosophy, and will finish with a brief glance at the Pagan reaction of the fourth century, when the old religion, already full of allegory, mysticism, asceticism, and Oriental influences, raised itself for a last indignant stand against the all-prevailing deniers of the gods.

This period, however, admits a rather simpler treatment than the others. It so happens that for the last period of paganism we actually possess an authoritative statement of doctrine, something between a creed and a catechism. It seems to me a document so singularly important and, as far as I can make out, so little known, that I shall venture to print it entire. 
A creed or catechism is, of course, not at all the same thing as the real religion of those who subscribe to it. The rules of metre are not the same thing as poetry; the rules of cricket, if the analogy may be excused, are not the same thing as good play. Nay, more. A man states in his creed only the articles which he thinks it right to assert positively against those who think otherwise. His deepest and most practical beliefs are those on which he acts without question, which have never occurred to him as being open to doubt. If you take on the one hand a number of persons who have accepted the same creed but lived in markedly different ages and societies, with markedly different standards of thought and conduct, and on the other an equal number who profess different creeds but live in the same general environment, I think there will probably be more real identity of religion in the latter group. Take three orthodox Christians, enlightened according to the standards of their time, in the fourth, the sixteenth, and the twentieth centuries respectively, I think you will find more profound differences of religion between them than between a Methodist, a Catholic, a Freethinker, and even perhaps a welleducated Buddhist or Brahmin at the present day, provided you take the most generally enlightened representatives of each class. Still, when a student is trying to understand the inner religion of the ancients, he realizes how immensely valuable a creed or even a regular liturgy would be.

Literature enables us sometimes to approach pretty close, in various ways, to the minds of certain of the 
great men of antiquity, and understand how they thought and felt about a good many subjects. At times one of these subjects is the accepted religion of their society; we can see how they criticized it or rejected it. But it is very hard to know from their reactions against it what that accepted religion really was. Who, for instance, knows Herodotus's religion? $\mathrm{He}$ talks in his penetrating and garrulous way, 'sometimes for children and sometimes for philosophers,' as Gibbon puts it, about everything in the world; but at the end of his book you find that he has not opened his heart on this subject. No doubt his profession as a reciter and story-teller prevented him. We can see that Thucydides was sceptical; but can we fully see what his scepticism was directed against, or where, for instance, Nikias would have disagreed with him, and where he and Nikias both agreed against us?

We have, of course, the systems of the great philosophers-especially of Plato and Aristotle. Better than either, perhaps, we can make out the religion of M. Aurelius. Amid all the harshness and plainness of his literary style, Marcus possessed a gift which has been granted to few, the power of writing down what was in his heart just as it was, not obscured by any consciousness of the presence of witnesses or any striving after effect. He does not seem to have tried deliberately to reveal himself, yet he has revealed himself in that short personal note-book almost as much as the great inspired egotists, Rousseau and St. Augustine. True, there are some passages in the book which are unintelligible to us; that is 
natural in a work which was not meant to be read by the public; broken flames of the white passion that consumed him bursting through the armour of his habitual accuracy and self-restraint.

People fail to understand Marcus, not because of his lack of self-expression, but because it is hard for most men to breathe at that intense height of spiritual life, or, at least, to breathe soberly. They can do it if they are allowed to abandon themselves to floods of emotion, and lose self-judgement and self-control. I am often rather surprised at good critics speaking of Marcus as ' cold'. 'There is as much intensity of feeling in T'à

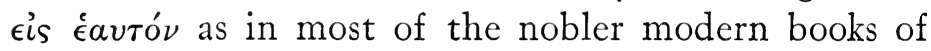
religion, only there is a sterner power controlling it. The feeling never amounts to complete self-abandonment. ' The Guiding Power' never trembles upon its throne, and the emotion is severely purged of earthly dross. That being so, we children of earth respond to it less readily.

Still, whether or no we can share Marcus's religion, we can at any rate understand most of it. But even then we reach only the personal religion of a very extraordinary man; we are not much nearer to the religion of the average educated person-the background against which Marcus, like Plato, ought to stand out. I believe that our conceptions of it are really very vague and various. Our great-grandfathers who read 'Tully's Offices and Ends were better informed than we. But there are many large and apparently simple questions about which, even after 
reading Cicero's philosophical translations, scholars probably feel quite uncertain. Were the morals of Epictetus or the morals of Part V of the Anthology most near to those of real life among respectable persons? Are there not subjects on which Plato himself sometimes makes our flesh creep? What are we to feel about slavery, about the exposing of children? True, slavery was not peculiar to antiquity; it flourished in a civilized and peculiarly humane people of English blood till a generation ago. And the history of infanticide among the finest modern nations is such as to make one reluctant to throw stones, and even doubtful in which direction to throw them. Still, these great facts and others like them have to be understood, and are rather hard to understand, in their bearing on the religious life of the ancients.

Points of minor morals again are apt to surprise a reader of ancient literature. We must remember, of course, that they always do surprise one, in every age of history, as soon as its manners are studied in detail. One need not go beyond Salimbene's Chronicle, one need hardly go beyond Macaulay's History, or any of the famous French memoirs, to realize that. Was it really an ordinary thing in the first century, as Philo seems to say, for gentlemen at dinner-parties to black one another's eyes or bite one another's ears off ? ${ }^{1}$ Or were such practices confined to some Smart Set? Or was Philo, for his own purposes, using some particular scandalous occurrence as if it was typical?

St. Augustine mentions among the virtues of his

$$
1 \text { De Vit. Contempl., p. } 477 \text { M. }
$$


mother her unusual meekness and tact. Although her husband had a fiery temper, she never had bruises on her face, which made her a rara avis among the matrons of her circle. ${ }^{1}$ Her circle, presumably, included Christians as well as Pagans and Manicheans. And Philo's circle can scarcely be considered Pagan. Indeed, as for the difference of religion, we should bear in mind that, just at the time we are about to consider, the middle of the fourth century, the conduct of the Christians, either to the rest of the world or to one another, was very far from evangelical. Ammianus says that no savage beasts could equal its cruelty; Ammianus was a pagan; but St. Gregory himself says it was like Hell. ${ }^{2}$

I have expressed elsewhere my own general answer to this puzzle. ${ }^{3}$ Not only in early Greek times, but throughout the whole of antiquity the possibility of all sorts of absurd and atrocious things lay much nearer, the protective forces of society were much weaker, the strain on personal character, the need for real 'wisdom and virtue', was much greater than it is at the present day. That is one of the causes that make antiquity so interesting. Of course, different periods of antiquity varied greatly, both in the conventional standard demanded and in the spiritual force which answered or surpassed the demand. But, in general, the strong governments and orderly societies of modern Europe have made it infinitely easier for men of no particular virtue to live a decent life, infinitely easier also for

1 Conf. ix. 9. ${ }^{2}$ Gibbon, chap. xxi, notes 161, 162. 3 Rise of the Greek Epic, chap. i. 
men of no particular reasoning power or scientific knowledge to have a more or less scientific or sane view of the world.

That, however, does not carry us far towards solving the main problem: it brings us no nearer to knowledge of anything that we may call typically a religious creed or an authorized code of morals, in any age from Hesiod to M. Aurelius.

The book which I have ventured to call a Creed or Catechism is the work of Sallustius About the Gods and the World, a book, I should say, about the length of the Scotch Shorter Catechism. It is printed in the third volume of Mullach's Fragmenta Pbilosophorum; apart from that, the only edition generally accessible-and that is rare-is a duodecimo published by Allatius in 1539 . Orelli's brochure of $182 \mathrm{I}$ seems unprocurable.

The author was in all probability that Sallustius who is known to us as a close friend of Julian before his accession, and a backer or inspirer of the emperor's efforts to restore the old religion. He was concerned in an educational edition of Sophocles-the seven selected plays now extant with a commentary. He was given the rank of prefect in 362 , that of consul in 363 . One must remember, of course, that in that rigorous and ascetic court high rank connoted no pomp or luxury. Julian had dismissed the thousand hairdressers, the innumerable cooks and eunuchs of his Christian predecessor. It probably brought with it only an increased obligation to live on pulse and to do 
without such pamperings of the body as fine clothes or warmth or washing.

Julian's fourth oration, a prose hymn To King

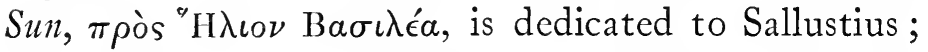
his eighth is a 'Consolation to Himself upon the Departure of Sallustius'. (He had been with Julian in the wars in Gaul, and was recalled by the jealousy of the emperor Constantius.) It is a touching and even a noble treatise. The nervous self-distrust which was habitual in Julian makes him write always with a certain affectation, but no one could mistake the real feeling of loss and loneliness that runs through the consolation. He has lost his 'comrade in the ranks', and now is 'Odysseus left alone'. So he writes, quoting the Iliad; Sallustius has been carried by God outside the spears and arrows: "which malignant men were always aiming at you, or rather at me, trying to wound me through you, and believing that the only way to beat me down was by depriving me of the fellowship of my true friend and fellow-soldier, the comrade who never flinched from sharing my dangers.'

One note recurs four times; he has lost the one man to whom he could talk as a brother; the man of 'guileless and clean free-speech,' 1 who was honest and unafraid and able to contradict the emperor freely because of their mutual trust. If one thinks of it, Julian, for all his gentleness, must have been an alarming emperor to converse with. His standard of conduct was not only uncomfortably high, it was also a little unaccountable. The most correct and blameless court

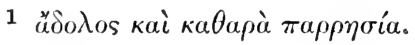


officials must often have suspected that their master looked upon them as simply wallowing in sin. And that feeling does not promote ease or truthfulness. Julian compares his friendship with Sallustius to that of Scipio and Laelius. People said of Scipio that he only carried out what Laelius told him. 'Is that true of me?' Julian asks himself. 'Have I only done what Sallustius

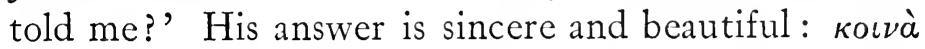
$\tau \grave{a} \phi \hat{\imath} \lambda \omega \nu$. It little matters who suggested, and who agreed to the suggestion; his thoughts and any credit that came from the thoughts, are his friend's as much as his own. We happen to hear from the Christian Theodoret (Hist. iii. II) that on one occasion when Julian was nearly goaded into persecution of the Christians, it was Sallustius who recalled him to their fixed policy of toleration.

Sallustius then may be taken to represent in the most authoritative way the Pagan reaction of Julian's time, in its final struggle against Christianity.

He was a Neo-Platonist, that is clear. But it is not as a professed philosopher that he writes. It is only that Neo-Platonism had permeated the whole atmosphere of the age. The strife of the philosophical sects had almost ceased. Just as Julian's mysticism made all gods and almost all forms of worship into one, so his enthusiasm for Hellenism revered, nay, idolized, almost all the great philosophers of the past. They were all trying to say the same ineffable thing; all lifting mankind towards the knowledge of God. I say 'almost' in both cases: for the Christians are outside the pale in one domain and the Epicureans 
and a few Cynics in the other. Both had committed the cardinal sin; they had denied the gods. They are sometimes lumped together as Atheoi. L'athéisme, voilà l'ennemi.

This may surprise us at first sight, but the explanation is easy. To Julian the one great truth that matters is the presence and glory of the gods. No doubt, they are all ultimately one; they are $\delta v \nu a ́ \mu \epsilon \iota s$, ' forces,' not persons, but for reasons above our comprehension they are manifest only under conditions of form, time, and personality, and have so been revealed and worshipped and partly known by the great minds of the past. In Julian's mind the religious emotion itself becomes the thing to live for. Every object that has been touched by that emotion is thereby glorified and made sacred. Every shrine where men have worshipped in truth of heart is thereby a house of God. The worship may be mixed up with all sorts of folly, all sorts of unedifying practice. Such things must be purged away, or, still better, must be properly understood. For to the pure all things are pure; and the myths that shock the vulgar are noble allegories to the wise and reverent. Purge religion from dross, if you like; but remember that you do so at your peril. One false step, one self-confident rejection of a thing which is merely too high for you to grasp, and you are darkening the Sun, casting God out of the world. And that was just what the Christians deliberately did. In many of the early Christian writings denial is a much greater element than assertion. The beautiful Octavius of Minucius Felix (Bishop in 3I5) 
is an example. Such denial was, of course, to our judgement, eminently needed, and rendered a great service to the world. But to Julian it seemed impiety. In other Christian writings the misrepresentation of pagan rites and beliefs is decidedly foul-mouthed and malicious. Quite apart from his personal wrongs and his contempt for the character of Constantius, Julian could have no sympathy for men who overturned altars and heaped blasphemy on old deserted shrines, defilers of every sacred object that was not protected by popularity. The most that such people could expect from him was that they should not be proscribed bylaw.

But meantime what were the multitudes of the god-fearing to believe? The arm of the state was not very strong or effective. Labour as he might to supply good teaching to all provincial towns, Julian could not hope to educate the poor and ignorant to understand Plato and M. Aurelius. For them, he seems to say, all that is necessary is that they should be pious and god-fearing in their own way. But for more or less educated people, not blankly ignorant, and yet not professed students of philosophy, there might be some simple and authoritative treatise issueda sort of reasoned creed, to lay down in a convincing manner the outlines of the old Hellenic religion, before the Christians and Atheists should have swept all fear of the gods from off the earth.

The treatise is this work of Sallustius.

The Christian fathers from Minucius Felix onward have shown us what was the most vulnerable point of 
Paganism : the traditional mythology. Sallustius deals with it at once. The Akroâtês, or pupil, he says in Section I, needs some preliminary training. He should have been well brought up, should not be incurably stupid, and should not have been familiarized with foolish fables. Evidently the mythology was not to be taught to children. He enunciates certain postulates of religious thought, viz. that God is always good and not subject to passion or to change, and then proceeds straight to the traditional myths. In the first place, he insists that they are what he calls 'divine'. That is, they are inspired or have some touch of divine truth in them. This is proved by the fact that they have been uttered, and sometimes invented, by the most inspired poets and philosophers and by the gods themselves in oracles-a very characteristic argument.

The myths are all expressions of God and of the goodness of God; but they follow the usual method of divine revelation, to wit, mystery and allegory. The myths state clearly the one tremendous fact that the Gods are; that is what Julian cared about and the Christians denied : what they are the myths reveal only to those who have understanding. "'The world itself is a great myth, in which bodies and inanimate things are visible, souls and minds invisible.'

'But, admitting all this, how comes it that the myths are so often absurd and even immoral?' For the usual purpose of mystery and allegory; in order to make people think. The soul that wishes to know God must make its own effort; it cannot 
expect simply to lie still and be told. The myths by their obvious falsity and absurdity on the surface stimulate the mind capable of religion to probe deeper.

$\mathrm{He}$ proceeds to give instances, and chooses at once myths that had been for generations the mock of the sceptic, and in his own day furnished abundant ammunition for the artillery of Christian polemic. He takes first Hesiod's story of Kronos swallowing his children; then the Judgement of Paris; then comes a long and earnest explanation of the myth of Attis and the Mother of the Gods. It is on the face of it a story highly discreditable both to the heart and the head of those august beings, and though the rites themselves do not seem to have been in any way improper, the Christians naturally attacked the Pagans and Julian personally for countenancing the worship. Sallustius's explanation is taken directly from Julian's fifth oration in praise of the Great Mother, and reduces the myth and the ritual to an expression of the adventures of the Soul seeking God.

So much for the whole traditional mythology. It has been explained completely away and made subservient to philosophy and edification, while it can still be used as a great well-spring of religious emotion. For the explanations given by Sallustius and Julian are never rationalistic. They never stimulate a spirit of scepticism, always a spirit of mysticism and reverence. And, lest by chance even this reverent theorizing should have been somehow lacking in insight or true piety, Sallustius ends with the prayer: "When I say these things concerning the myths, may the gods 
themselves and the spirits of those who wrote the myths be gracious to me.'

$\mathrm{He}$ now leaves mythology and turns to the First Cause. It must be one, and it must be present in all things. Thus, it cannot be Life, for, if it were, all things would be alive. By a Platonic argument in which he will still find some philosophers to follow him, he proves that everything which exists, exists because of some goodness in it; and thus arrives at the conclusion that the First Cause is $\tau o$ ' a $\gamma \alpha \theta$ ó $\nu$, the Good.

The gods are emanations or forces issuing from the Good; the makers of this world are secondary gods; above them are the makers of the makers, above all the One.

Next comes a proof that the world is eternal-a very important point of doctrine; next that the soul is immortal; next a definition of the workings of Divine Providence, Fate, and Fortune-a fairly skilful piece of dialectic dealing with a hopeless difficulty. Next come Virtue and Vice, and, in a dead and perfunctory echo of Plato's Republic, an enumeration of the good and bad forms of human society. The questions which vibrated with life in free Athens had become meaningless to a despot-governed world. Then follows more adventurous matter.

First a chapter headed: 'Whence Evil things come, and that there is no Pbusis Kakou-Evil is not a real thing.' 'It is perhaps best,' he says, 'to observe at once that, since the gods are good and make everything, there is no positive evil; there is only absence of good; just as there is no positive darkness, only absence of light.' 
What we call ' evils' arise only in the activities of men, and even here no one ever does evil for the sake of evil. 'One who indulges in some pleasant vice thinks the vice bad but his pleasure good; a murderer thinks the murder bad, but the money he will get by it, good; one who injures an enemy thinks the injury bad, but the being quits with his enemy, good'; and so on. The evil acts are all done for the sake of some good, but human souls, being very far removed from the original flawless divine nature, make mistakes or sins. One of the great objects of the world, he goes on to explain, of gods, men, and spirits, of religious institutions and human laws alike, is to keep the souls from these errors and to purge them again when they have fallen.

Next comes a speculative difficulty. Sallustius has called the world 'eternal in the fullest sense'-that is, it always has been and always will be. And yet it is 'made' by the gods. How are these statements compatible? If it was made, there must have been a time before it was made. The answer is ingenious. It is not made by handicraft as a table is; it is not begotten as a son by a father. It is the result of a quality of God just as light is the result of a quality of the sun. The sun causes light, but the light is there as soon as the Sun is there. The world is simply the other side, as it were, of the goodness of God, and has existed as long as that goodness has existed.

Next come some simpler questions about man's relation to the gods. In what sense can we say that 
the gods are angry with the wicked or are appeased by repentance? Sallustius is quite firm. The gods cannot ever be glad-for that which is glad is also sorry; cannot be angry-for anger is a passion ; and obviously they cannot be appeased by gifts or prayers. Even men, if they are honest, require higher motives than that. God is unchangeable, always good, always doing good. If we are good, we are nearer to the gods, and we feel it ; if we are evil, ve are separated further from them. It is not they that are angry, it is our sins that hide them from us and prevent the goodness of God from shining into us. If we repent, again, we do not make any change in God; we only, by the conversion of our soul towards the divine, heal our own badness and enjoy again the goodness of the gods. To say that the gods turn away from the wicked, would be like saying that the sun turns away from a blind man.

Why then do we make offerings and sacrifices to the gods, when the gods need nothing and can have nothing added to them? We do so in order to have more communion with the gods. The whole temple service, in fact, is an elaborate allegory, a representation of the divine government of the world.

The custom of sacrificing animals had died out some time before this. The Jews of the Dispersion had given it up long since because the Law forbade any such sacrifice outside the Temple. ${ }^{1}$ When Jerusalem was destroyed Jewish sacrifice ceased altogether. The Christians seem from the beginning to have generally followed the Jewish practice. But sacrifice was in

1 S. Reinach, Orpheus, p. 273 (Engl. trans., p. 185). 
itself not likely to continue in a society of large towns. It meant turning your temples into very ill-conducted slaughter-houses, and was also associated with a great deal of muddled and indiscriminate charity. ${ }^{1}$ One might have hoped that men so high-minded and spiritual as Julian and Sallustius would have considered this practice unnecessary or even have reformed it away. But no. It was part of the genuine Hellenic tradition; and no jot or tittle of that tradition should, if they could help it, be allowed to die. Sacrifice is desirable, argues Sallustius, because it is a gift of life. God has given us life, as He has given us all else. We must, therefore, pay to Him some emblematic tithe of life. Again, prayers in themselves are merely words; but with sacrifice they are words plus life, Living Words. Lastly, we are Life of a sort, and God is Life of an infinitely higher sort. To approach Him we need always a medium or a mediator; the medium between life and life must needs be life. We find that life in the sacrificed animal. ${ }^{2}$

The argument shows what ingenuity these religious men had at their command, and what trouble they would take to avoid having to face a fact and reform a bad system.

1 See Ammianus, xxii. I2, on the bad effect of Julian's sacrifices. Sacrifice was finally forbidden by the emperor Theodosius in 39I.

2 Sallustius's view of sacrifice is curiously like the illuminating theory of MM. Hubert and Mauss, in which they define primitive sacrifice as a medium, a bridge or lightning-conductor, between the profane and the sacred. 'Essai sur la Nature et la Fonction du Sacrifice' (Année Sociologique, ii. 1897-8), since republished in the Mélanges d'Histoire des Religions, 1909. 
There follows a long and rather difficult argument to show that the world is, in itself, eternal. The former discussion on this point had only shown that the gods would not destroy it. This shows that its own nature is indestructible. The arguments are very inconclusive, though clever, and one wonders why the author is at so much pains. Indeed, he is so earnest that at the end of the chapter he finds it necessary to apologize io the Kosmos in case his language should have been indiscreet. The reason, I think, is that the Christians were still, as in apostolic times, pinning their faith to the approaching end of the world by fire. ${ }^{1}$ They announced the end of the worid as near, and they rejoiced in the prospect of its destruction. History has shown more than once what terrible results can be produced by such beliefs as these in the minds of excitable and suffering populations, especially those of eastern blood. It was widely believed that Christian fanatics had from time to time actually tried to light fires which should consume the accursed world and thus hasten the coming of the kingdom which should bring such incalculable rewards to their own organization and plunge the rest of mankind in everlasting torment. To any respectable Pagan such action was an insane crime made worse by a

${ }^{1}$ Cf. Minucius Felix, Octavius, p. 96, Ouzel (chap. II, Boenig). 'Quid quod toti orbi et ipsi mundo cum sideribus suis minantur incendium, ruinam moliuntur?' The doctrine in their mouths became a very different thing from the Stoic theory of the periodic re-absorption of the universe in the Divine Element. Ibid., pp. $322 \mathrm{ff}$. (34 Boenig). 
diabolical motive. The destruction of the world, therefore, seems to have become a subject of profound irritation, if not actually of terror. At any rate the doctrine lay at the very heart of the perniciosa superstitio, and Sallustius uses his best dialectic against it.

The title of Chapter XVIII has a somewhat pathetic ring: 'Why are Atheiai'-Atheisms or rejections of God-' permitted, and that God is not injured there-

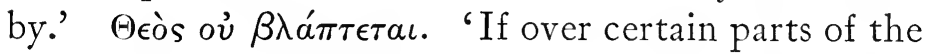
world there have occurred (and will occur more hereafter) rejections of the gods, a wise man need not be disturbed at that.' We have always known that the human soul was prone to error. God's providence is there; but we cannot expect all men at all times and places to enjoy it equally. In the human body it is only the eye that sees the light, the rest of the body is ignorant of the light. So are many parts of the earth ignorant of God.

Very likely, also, this rejection of God is a punishment. Persons who in a previous life have known the gods but disregarded them, are perhaps now born, as it were, blind, unable to see God; persons who have committed the blasphemy of worshipping their own kings as gods may perhaps now be cast out from the knowledge of God.

Philosophy had always rejected the Man-God, especially in the form of King-worship ; but opposition to Christianity no doubt intensifies the protest.

The last chapter is very short. "Souls that have lived in virtue, being otherwise blessed and especially separated from their irrational part and purged of all 
body, are joined with the gods and sway the whole world together with them.' So far triumphant faith : then the after-thought of the brave man who means to live his best life even if faith fail him. 'But even if none of these rewards came to them, still Virtue itself and the Joy and Glory of Virtue, and the Life that is subject to no grief and no master, would be enough to make blessed those who have set themselves to live in Virtue and have succeeded.'

There the book ends. It ends upon that well-worn paradox which, from the second book of the Republic onwards, seems to have brought so much comfort to the nobler spirits of the ancient world. Strange how we moderns cannot rise to it! We seem simply to lack the intensity of moral enthusiasm. When we speak of martyrs being happy on the rack; in the first place we rarely believe it, and in the second we are usually supposing that the rack will soon be over and that harps and golden crowns will presently follow. The ancient moralist believed that the good man was happy then and there, because the joy, being in his soul, was not affected by the torture of his body. ${ }^{1}$

Not being able fully to feel this conviction, we naturally incline to think it affected or unreal. But, taking the conditions of the ancient world into account, we must admit that the men who uttered this belief at least understood better than most of us what suffering was. Many of them were slaves, many had been

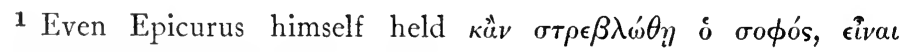

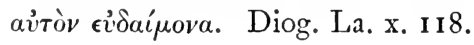


captives of war. They knew what they were talking about. I think, on a careful study of M. Aurelius, Epictetus, and some of these Neo-Platonic philosophers, that we shall be forced to realize that these men could rise to much the same heights of religious heroism as the Catholic saints of the Middle Age, and that they often did so-if I may use such a phrase-on a purer and thinner diet of sensuous emotion, with less wallowing in the dust and less delirium.

Be that as it may, we have now seen in outline the kind of religion which ancient Paganism had become at the time of its final reaction against Christianity. It is a more or less intelligible whole, and succeeds better than most religions in combining two great appeals. It appeals to the philosopher and the thoughtful man as a fairly complete and rational system of thought, which speculative and enlightened minds in any age might believe without disgrace. I do not mean that it is probably true; to me all these overpowering optimisms which, by means of a few untested a priori postulates, affect triumphantly to disprove the most obvious facts of life, seem very soon to become meaningless. I conceive it to be no comfort at all, to a man suffering agonies of frost-bite, to be told by science that cold is merely negative and does not exist. So far as the statement is true it is irrelevant; so far as it pretends to be relevant it is false. I only mean that a system like that of Sallustius is, judged by any standard, high, civilized, and enlightened.

At the same time this religion appeals to the P. P. 648 
ignorant and the humble-minded. It takes from the pious villager no single object of worship that has turned his thoughts heavenwards. It may explain and purge; it never condemns or ridicules. In its own eyes that was its great glory, in the eyes of history perhaps its most fatal weakness. Christianity, apart from its positive doctrines, had inherited from Judaism the courage of its disbeliefs.

To compare this Paganism in detail with its great rival would be, even if I possessed the necessary learning, a laborious and unsatisfactory task. But if a student with very imperfect knowledge may venture a personal opinion on this obscure subject, it seems to me that we often look at such problems from a wrong angle. Harnack somewhere, in discussing the comparative success or failure of various early Christian sects, makes the illuminating remark that the main determining cause in each case was not their comparative reasonableness of doctrine or skill in controversy - for they practically never converted one anotherbut simply the comparative increase or decrease of the birth-rate in the respective populations. On somewhat similar lines it always appears to me that, historically speaking, the character of Christianity in these early centuries is to be sought not so much in the doctrines which it professed, nearly all of which had their roots and their close parallels in older Hellenistic or Hebrew thought, but in the organization on which it rested. For my own part, when I try to understand Christianity as a mass of doctrines, Gnostic, Trinitarian, Monophysite, Arian and the rest, I get no further. 
When I try to realize it as a sort of semi-secret society for mutual help with a mystical religious basis, resting first on the proletariates of Antioch and the great commercial and manufacturing towns of the Levant, then spreading by instinctive sympathy to similar classes in Rome and the West, and rising in influence, like certain other mystical cults, by the special appeal it made to women, the various historical puzzles begin to fall into place. Among other things this explains the strange subterranean power by which the emperor Diocletian was baffled, and to which the pretender Constantine had to capitulate; it explains its humanity, its intense feeling of brotherhood within its own bounds, its incessant care for the poor, and also its comparative indifference to the virtues which are specially incumbent on a governing class, such as statesmanship, moderation, truthfulness, active courage, learning, culture, and public spirit. Of course such indifference was only comparative. After the time of Constantine the governing classes come into the fold, bringing with them their normal qualities, and thereafter it is Paganism, not Christianity, that must uphold the flag of a desperate fidelity in the face of a hostile world-a task to which, naturally enough, Paganism was not equal. But I never wished to pit the two systems against one another. The battle is over, and it is poor work to jeer at the wounded and the dead. If we read the literature of the time, especially some records of the martyrs under Diocletian, we shall at first perhaps imagine that, apart from some startling exceptions, the conquered party were all vicious and 
hateful, the conquerors all wise and saintly. Then, looking a little deeper, we shall see that this great controversy does not stand altogether by itself. As in other wars, each side had its wise men and its foolish, its good men and its evil. Like other conquerors these conquerors were often treacherous and brutal; like other vanquished these vanquished have been tried at the bar of history without benefit of counsel, have been condemned in their absence and died with their lips sealed. The polemic literature of Christianity is loud and triumphant, the books of the Pagans have been destroyed.

Only an ignorant man will pronounce a violent or bitter judgement here. The minds that are now tender, timid, and reverent in their orthodoxy would probably in the third or fourth century have sided with the old gods; those of more daring and puritan temper with the Christians. The historian will only try to have sympathy and understanding for both. They are all dead now, Diocletian and Diognêtus, Cyril and Hypatia, Julian and Basil, Arîus and Athanasius : every party has yielded up its persecutors and its martyrs, its hates and slanders and aspirations and heroisms, to the arms of that great Silence whose secrets they all claimed so loudly to have read. Even the dogmas for which they fought might seem to be dead too. For if Julian and Sallustius, Gregory and John Chrysostom, were to rise again and see the world as it now is, they would probably feel their personal differences melt away in comparison with the vast difference between their world and this. They fought 
to the death about this credo and that, but the same spirit was in all of them. In the words of one who speaks with greater knowledge than mine, 'the most inward man in these four contemporaries is the same. It is the Spirit of the Fourth Century.' 1

'Dieselbe Seelenstimmung, derselbe Spiritualismus;' also the same passionate asceticism. All through antiquity the fight against luxury was a fiercer and stronger fight than comes into our modern experience. There was not more objective luxury in any period of ancient history than there is now ; there was not anything like so much. But there does seem to have been more subjective abandonment to physical pleasure and concomitantly a stronger protest against it. From some time before the Christian era it seems as if the subconscious instinct of humanity was slowly rousing itself for a great revolt against the long intolerable tyranny of the senses over the soul, and by the fourth century the revolt threatened to become all-absorbing. The Emperor Julian was probably as proud of his fireless cell and the crowding lice in his beard and cassock as an average Egyptian monk. The ascetic movement grew, as we all know, to be measureless and insane. It seemed to be almost another form of lust, and to have the same affinities with cruelty. But it has probably rendered priceless help to us who come afterwards. The insane ages have often done service for the sane, the harsh and suffering ages for the gentle and well-to-do.

1 Geffcken in the Neue Fabrbïcher, xxi. $162 \mathrm{f}$. 
Sopbrosynê, however we try to translate it, temperance, gentleness, the spirit that in any trouble thinks and is patient, that saves and not destroys, is the right spirit. And it is to be feared that none of these fourth-century leaders, neither the fierce bishops with their homilies on Charity, nor Julian and Sallustius with their worship of Hellenism, came very near to that classic ideal. To bring back that note of Sophrosynê I will venture, before proceeding to the fourth-century Pagan creed, to give some sentences from an earlier Pagan prayer. It is cited by Stobaeus from a certain Eusebius, a late Ionic Platonist of whom almost nothing is known, not even the date at which he lived. ${ }^{1}$ But the voice sounds like that of a stronger and more sober age.

'May I be no man's enemy', it begins, ' and may I be the friend of that which is eternal and abides. May I never quarrel with those nearest to me; and if I do, may I be reconciled quickly. May I never devise evil against any man; if any devise evil against me, may I escape uninjured and without the need of hurting him. May I love, seek, and attain only that which is good. May I wish for all men's happiness and envy none. May I never rejoice in the ill-fortune of one who has wronged me. ... When I have done or said what is wrong, may I never wait for the rebuke of others, but always rebuke myself until I make amends. . . . May I win no victory that harms either me or my opponent. . . . May I reconcile friends who are wroth with one another. May I, to the extent of my power, give all needful help to my friends and to all who are in want. May I never fail a friend in danger. When visiting those in grief may $I$ be able by

1 Mullach, Fragmenta Pbilosophorum, iii. 7, from Stob. Flor. i. 85. 
gentle and healing words to soften their pain. ... May I respect myself. . . . May I always keep tame that which rages within me. . . May I accustom myself to be gentle, and never be angry with people because of circumstances. May I never discuss who is wicked and what wicked things he has done, but know good men and follow in their footsteps.'

There is more of it. How unpretending it is and yet how searching! And in the whole there is no petition for any material blessing, and-most striking of all-it is addressed to no personal god. It is pure prayer. Of course to some it will feel thin and cold. Most men demand of their religion more outward and personal help, more physical ecstasy, a more heady atmosphere of illusion. No one man's attitude towards the Uncharted can be quite the same as his neighbour's. In part instinctively, in part superficially and self-consciously, each generation of mankind reacts against the last. The grown man turns from the lights that were thrust upon his eyes in childhood. The son shrugs his shoulders at the watchwords that thrilled his father, and with varying degrees of sensitiveness or dullness, of fuller or more fragmentary experience, writes out for himself the manuscript of his creed. Yet, even for the wildest or bravest rebel, that manuscript is only a palimpsest. On the surface all is new writing, clean and selfassertive. Underneath, dim but indelible in the very fibres of the parchment, lie the characters of many ancient aspirations and raptures and battles which his conscious mind has rejected or utterly forgotten. 
And forgotten things, if there be real life in them, will sometimes return out of the dust, vivid to help still in the forward groping of humanity. A religious system like that of Eusebius or Marcus, or even Sallustius, was not built up without much noble life and strenuous thought and a steady passion for the knowledge of God. 'Things of that make do not, as a rule, die for ever. 


\section{SALLUSTIUS}

'ON THE GODS AND THE WORLD' 



\section{SALLUSTIUS}

\section{'ON THE GODS AND THE WORLD'’}

\section{What the Disciple should be; and concerning Common Conceptions.}

Those who wish to hear about the Gods should have been well guided from childhood, and not habituated to foolish beliefs. They should also be in disposition good and sensible, that they may properly attend to the teaching.

They ought also to know the Common Conceptions. Common Conceptions are those to which all men agree as soon as they are asked: for instance that all God is good, free from passion, free from change. For whatever suffers change does so for the worse or the better: if for the worse, it is made bad, if for the better, it must have been bad at first.

1 I translate kó $\sigma \mu o s$ generally as 'World', sometimes as 'Cosmos'. It always has the connotation of 'divine order'; $\psi v \chi \eta$ ' always 'Soul', to keep it distinct from ' $\zeta \omega \eta$, ' physical life', though often 'Life' would be a more natural English equivalent; '̇ $\mu \psi v \chi 0 \hat{v} v$ 'to animate'; ovoía sometimes 'essence', sometimes 'being' (never 'substance' or 'nature'); $\phi \dot{v} \sigma \iota s$ 'nature'; $\sigma \hat{\omega} \mu \alpha$ sometimes 'body', sometimes 'matter'. 


\section{That God is unchanging, un-begotten, eternal, incorporeal, and not in space.}

Let the disciple be thus. Let the teachings be of the following sort. The essences of the Gods never came into existence (for that which always is never comes into existence; and that exists for ever which possesses primary force and by nature suffers nothing): neither do they consist of bodies; for even in bodies the powers are incorporeal. Neither are they contained by space; for that is a property of bodies. Neither are they separate from the First Cause nor from one another, just as thoughts are not separate from mind nor acts of knowledge from the soul.

III. Concerning myths; that they are divine and why.

We may well inquire, then, why the ancients forsook these doctrines and made use of myths. There is this first benefit from myths, that we have to search and do not have our minds idle.

That the myths are divine can be seen from those who have used them. Myths have been used by inspired poets, by the best of philosophers, by those who established the mysteries, and by the Gods themselves in oracles. But why the myths are divine it is the duty of Philosophy to inquire. Since all existing things rejoice in that which is like them and reject that which is unlike, the stories about the Gods ought to be like the Gods, so that they may both be 
worthy of the divine essence and make the Gods well disposed to those who speak of them : which could only be done by means of myths.

Now the myths represent the Gods themselves and the goodness of the Gods-subject always to the distinction of the speakable and the unspeakable, the revealed and the unrevealed, that which is clear and that which is hidden: since, just as the Gods have made the goods of sense common to all, but those of intellect only to the wise, so the myths state the existence of Gods to all, but who and what they are only to those who can understand.

They also represent the activities of the Gods. For one may call the World a Myth, in which bodies and things are visible, but souls and minds hidden. Besides, to wish to teach the whole truth about the Gods to all produces contempt in the foolish, because they cannot understand, and lack of zeal in the good; whereas to conceal the truth by myths prevents the contempt of the foolish, and compels the good to practise philosophy.

But why have they put in the myths stories of adultery, robbery, father-binding, and all the other absurdity? Is not that perhaps a thing worthy of admiration, done so that by means of the visible absurdity the Soul may immediately feel that the words are veils and believe the truth to be a mystery ? 


\section{That the species of Myth are five, with examples of each.}

Of myths some are theological, some physical, some psychic, and again some material, and some mixed from these last two. The theological are those myths which use no bodily form but contemplate the very essences of the Gods: e.g. Kronos swallowing his children. Since God is intellectual, and all intellect returns into itself, this myth expresses in allegory the essence of God.

Myths may be regarded physically when they express the activities of the Gods in the world: e.g. people before now have regarded Kronos as Time, and calling the divisions of Time his sons say that the sons are swallowed by the father.

The psychic way is to regard the activities of the Soul itself : the Soul's acts of thought, though they pass on to other objects, nevertheless remain inside their begetters.

The material and last is that which the Egyptians have mostly used, owing to their ignorance, believing material objects actually to be Gods, and so calling them : e.g. they call the Earth Isis, moisture Osiris, heat Typhon, or again, water Kronos, the fruits of the carth Adonis, and wine Dionysus.

To say that these objects are sacred to the Gods, like various herbs and stones and animals, is possible to sensible men, but to say that they are gods is the notion of madmen-except, perhaps, in the sense in 
her cap of stars, and thereafter kept him with her. $\mathrm{He}$ fell in love with a nymph and left the Mother to live with her. For this the Mother of the Gods made Attis go mad and cut off his genital organs and leave them with the Nymph, and then return and dwell with her.

Now the Mother of the Gods is the principle that generates life; that is why she is called Mother. Attis is the creator of all things which are born and die; that is why he is said to have been found by the river Gallus. For Gallus signifies the Galaxy, or Milky Way, the point at which body subject to passion begins. ${ }^{1}$ Now as the primary gods make perfect the secondary, the Mother loves Attis and gives him celestial powers. That is what the cap means. Attis loves a nymph : the nymphs preside over generation, since all that is generated is fluid. But since the process of generation must be stopped somewhere, and not allowed to generate something worse than the worst, the Creator who makes these things casts away his generative powers into the creation and is joined to the gods again. Now these things never happened, but always are. And Mind sees all things at once, but Reason (or Speech) expresses some first and others after. Thus, as the myth is in accord with the Cosmos, we for that reason keep a festival imitating the Cosmos, for how could we attain higher order?

And at first we ourselves, having fallen from heaven and living with the Nymph, are in despondency, and

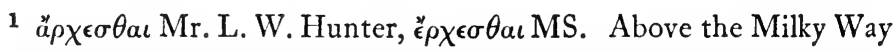
there is no such body, only spirit. Cf. Macrob. in Somn. Scip. i. I2. 


\section{'ON THE GODS AND THE WORLD'}

abstain from corn and all rich and unclean food, for both are hostile to the soul. Then comes the cutting of the tree and the fast, as though we also were cutting off the further process of generation. After that the feeding on milk, as though we were being born again; after which come rejoicings and garlands and, as it were, a return up to the Gods.

The season of the ritual is evidence to the truth of these explanations. The rites are performed about the Vernal Equinox, when the fruits of the earth are ceasing to be produced, and day is becoming longer than night, which applies well to Spirits rising higher. (At least, the other equinox is in mythology the time of the Rape of Korê, which is the descent of the souls.)

May these explanations of the myths find favour in the eyes of the Gods themselves and the souls of those who wrote the myths.

\section{On the First Cause.}

Next in order comes knowledge of the First Cause and the subsequent orders of the gods, then the nature of the world, the essence of intellect and of soul, then Providence, Fate, and Fortune, then to see Virtue and Vice and the various forms of social constitution good and bad that are formed from them, and from what possible source Evil came into the world.

Each of these subjects needs many long discussions; but there is perhaps no harm in stating them briefly, 
so that a disciple may not be completely ignorant about them.

It is proper to the First Cause to be One-for unity precedes multitude-and to surpass all things in power and goodness. Consequently all things must partake of it. For owing to its power nothing else can hinder it, and owing to its goodness it will not hold itself apart.

If the First Cause were Soul, all things would possess Soul. If it were Mind, all things would possess Mind. If it were Being, all things would partake of Being. Seeing this, some men have thought that it was Being. Now if things simply were, without being good, this argument would be true, but if things that are are because of their goodness, and partake in the good, the First thing must needs be both beyond-Being and good. It is strong evidence of this that noble souls despise Being for the sake of the good, when they face death for their country or friends or for the sake of virtue.-After this inexpressible power come the orders of the Gods.

\section{On Gods Cosmic and Hypercosmic.}

Of the Gods some are of the world, Cosmic, and some above the world, Hypercosmic. By the Cosmic I mean those who make the Cosmos. Of the Hypercosmic Gods some create Essence, some Mind, and some Soul. Thus they have three orders; all of which may be found in treatises on the subject.

Of the Cosmic Gods some make the World be, others 
animate it, others harmonize it, consisting as it does of different elements; the fourth class keep it when harmonized.

These are four actions, each of which has a beginning, middle, and end, consequently there must be twelve gods governing the world.

Those who make the world are 'Zeus, Poseidon, and Hephaistos; those who animate it are Demeter, Hera, and Artemis; those who harmonize it are Apollo, Aphrodite, and Hermes; those who watch over it are Hestia, Athena, and Ares.

One can see secret suggestions of this in their images. Apollo tunes a lyre; Athena is armed; Aphrodite is naked (because harmony creates beauty, and beauty in things seen is not covered).

While these twelve in the primary sense possess the world, we should consider that the other gods are contained in these. Dionysus in Zeus, for instance, Asklepios in Apollo, the Charites in Aphrodite.

We can also discern their various spheres: to Hestia belongs the Earth, to Poseidon water, to Hera air, to Hephaistos fire. And the six superior spheres to the gods to whom they are usually attributed. For Apollo and Artemis are to be taken for the Sun and Moon, the sphere of Kronos should be attributed to Demeter, the ether to Athena, while the heaven is common to all. Thus the orders, powers, and spheres of the Twelve Gods have been explained and celebrated in hymns. 


\section{On the Nature of the World and its Eternity.}

The Cosmos itself must of necessity be indestructible and uncreated. Indestructible because, suppose it destroyed: the only possibility is to make one better than this or worse or the same or a chaos. If worse, the power which out of the better makes the worse must be bad. If better, the maker who did not make the better at first must be imperfect in power. If the same, there will be no use in making it; if a chaos ... it is impious even to hear such a thing suggested. These reasons would suffice to show that the World is also uncreated : for if not destroyed, neither is it created. Everything that is created is subject to destruction. And further, since the Cosmos exists by the goodness of God it follows that God must always be good and the world exist. Just as light coexists with the Sun and with fire, and shadow coexists with a body.

Of the bodies in the Cosmos, some imitate Mind and move in orbits; some imitate Soul and move in a straight line, fire and air upward, earth and water downward. Of those that move in orbits the fixed sphere goes from the east, the Seven from the west. ('This is so for various causes, especially lest the creation should be imperfect owing to the rapid circuit of the spheres.) ${ }^{1}$

The movement being different, the nature of the bodies musi also be different; hence the celestial

1 i. e. if the Firmament or Fixed Sphere moved in the same direction as the seven Planets, the speed would become too great. 
body does not burn or freeze what it touches, or do anything else that pertains to the four elements. ${ }^{1}$

And since the Cosmos is a sphere-the zodiac proves that-and in every sphere 'down' means 'towards the centre', for the centre is furthest distant from every point, and heavy things fall 'down' and fall to the earth (it follows that the Earth is in the centre of the Cosmos $\rangle$.

All these things are made by the Gods, ordered by Mind, moved by Soul. About the Gods we have spoken already.

\section{On Mind and Soul, and that the latter is immortal.}

There is a certain force, ${ }^{2}$ less primary than Being but more primary than the Soul, which draws its existence from Being and completes the Soul as the Sun completes the eyes. Of Souls some are rational and immortal, some irrational and mortal. The former are derived from the first Gods, the latter from the secondary.

First, we must consider what soul is. It is, then, that by which the animate differs from the inanimate. The difference lies in motion, sensation, imagination, intelligence. Soul, therefore, when irrational, is the life

1 The fire of which the heavenly bodies are made is the $\pi \dot{\epsilon} \mu \pi \tau o v$ $\boldsymbol{\sigma} \hat{\omega} \mu a$, matter, but different from earthly matter. See p. II 7 .

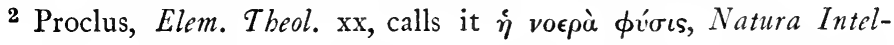
lectualis. There are four degrees of existence: lowest of all, Bodies; above that, Soul; above all Souls, this 'Intellectual Nature'; above that, The One. 
of sense and imagination; when rational, it is the life which controls sense and imagination and uses reason.

The irrational soul depends on the affections of the body; it feels desire and anger irrationally. The rational soul both, with the help of reason, despises the body, and, fighting against the irrational soul, produces either virtue or vice, according as it is victorious or defeated.

It must be immortal, both because it knows the gods (and nothing mortal knows ${ }^{1}$ what is immortal), it looks down upon human affairs as though it stood outside them, and, like an unbodied thing, it is affected in the opposite way to the body. For while the body is young and fine, the soul blunders, but as the body grows old it attains its highest power. Again, every good soul uses mind; but no body can produce mind : for how should that which is without mind produce mind? Again, while Soul uses the body as an instrument, it is not in it; just as the engineer is not in his engines (although many engines move without being touched by any one). And if the Soul is often made to err by the body, that is not surprising. For the arts cannot perform their work when their instruments are spoilt.

\section{On Providence, Fate, and Fortune.}

This is enough to show the Providence of the Gods. For whence comes the ordering of the world, if there is no ordering power? And whence comes the fact that all things are for a purpose: e.g. irrational soul 1 i.e. in the full sense of Gnôsis. 
that there may be sensation, and rational that the earth may be set in order?

But one can deduce the same result from the evidences of Providence in nature : e.g. the eyes have been made transparent with a view to seeing; the nostrils are above the mouth to distinguish bad-smelling foods; the front teeth are sharp, to cut food, the back teeth broad to grind it. And we find every part of every object arranged on a similar principle. It is impossible that there should be so much providence in the last details, and none in the first principles. Then the arts of prophecy and of healing, which are part of the Cosmos, come of the good providence of the gods.

All this care for the world, we must believe, is taken by the Gods without any act of will or labour. As bodies which possess some power produce their effects by merely existing : e.g. the sun gives light and heat by merely existing; so, and far more so, the Providence of the Gods acts without effort to itself and for the good of the objects of its forethought. This solves the problems of the Epicureans, who argue that what is Divine neither has trouble itself nor gives trouble to others.

The incorporeal providence of the Gods, both for bodies and for souls, is of this sort : but that which is of bodies and in bodies is different from this, and is called Fate, Heimarmenê, because the chain of causes (Heirmos) is more visible in the case of bodies; and it is for dealing with this Fate that the science of 'Mathematic' has been discovered. ${ }^{1}$

${ }^{1}$ i.e. Astrology, dealing with the 'Celestial Bodies'. 
Therefore, to believe that human things, especially their material constitution, are ordered not only by celestial beings but by the Celestial Bodies, is a reasonable and true belief. Reason shows that health and sickness, good fortune and bad fortune, arise according to our deserts from that source. But to attribute men's acts of injustice and lust to Fate, is to make ourselves good and the Gods bad. Unless by chance a man meant by such a statement that in general all things are for the good of the world and for those who are in a natural state, but that bad education or weakness of nature changes the goods of Fate for the worse. Just as it happens that the Sun, which is good for all, may be injurious to persons with ophthalmia or fever. Else why do the Massagetae eat their fathers, the Hebrews practise circumcision, and the Persians preserve rules of rank ? ${ }^{1}$ Why do astrologers, while calling Saturn and Mars 'malignant', proceed to make them good, attributing to them philosophy and royalty, generalships and treasures? And if they are going to talk of triangles and squares, it is absurd that gods should change their natures according to their position in space, while human virtue remains the same everywhere. Also the fact that the stars predict high or low rank for the father of the person whose horoscope is taken, teaches that they do not always make things happen but sometimes only indicate things. For how could things which preceded the birth depend upon the birth?

Further, as there is Providence and Fate concerned 1 Cf. Hdt. i. I34. 


\section{'ON THE GODS AND THE WORLD' 201}

with nations and cities, and also concerned with each individual, so there is also Fortune, which should next be treated. That power of the gods which orders for the good things which are not uniform, and which happen contrary to expectation, is commonly called Fortune, and it is for this reason that the goddess is especially worshipped in public by cities : for every city consists of elements which are not uniform. Fortune has power beneath the moon, since above the moon no single thing can happen by fortune.

If Fortune makes a wicked man prosperous and a good man poor, there is no need to wonder. For the wicked regard wealth as everything, the good as nothing. And the good fortune of the bad cannot take away their badness, while virtue alone will be enough for the good.

\section{Concerning Virtue and Vice.}

The doctrine of Virtue and Vice depends on that of the Soul. When the irrational soul enters into the body and immediately produces Fight and Desire, the rational soul, put in authority over all these, makes the soul tripartite, composed of Reason, Fight, and Desire. Virtue in the region of Reason is Wisdom, in the region of Fight is Courage, in the region of Desire it is Temperance; the virtue of the whole Soul is Righteousness. It is for Reason to judge what is right, for Fight in obedience to Reason to despise things that appear terrible, for Desire to pursue not the apparently desirable, but, that which 
is with Reason desirable. When these things are so, we have a righteous life; for righteousness in matters of property is but a small part of virtue. And thus we may find all four virtues in properly trained men, but among the untrained one may be brave and unjust, another temperate and stupid, another prudent and unprincipled. Indeed these qualities should not be called Virtues when they are devoid of Reason and imperfect and found in irrational beings. Vice should be regarded as consisting of the opposite elements. In Reason it is Folly, in Fight, Cowardice, in Desire, Intemperance, in the whole soul, Unrighteousness.

The virtues are produced by the right social organization and by good rearing and education, the vices by the opposite.

\section{Concerning right and wrong Social Organization. ${ }^{1}$}

Constitutions also depend on the tripartite nature of the Soul. The rulers are analogous to Reason, the soldiers to Fight, the common folk to Desires.

Where all things are done according to reason and the best man in the nation rules, it is a Kingdom; where more than one rule according to reason and fight, it is an Aristocracy; where the government is according to desire and offices depend on money, that constitution is called a Timocracy. The contraries are: to Kingdom tyranny, for Kingdom does all

${ }^{1}$ [This section is a meagre reminiscence of Plato's discussion in Repub. viii. The interest in politics and government had died out with the loss of political freedom.] 
things with the guidance of reason and Tyranny nothing; to Aristocracy oligarchy, when not the best people but a few of the worst are rulers; to Timocracy democracy, when not the rich but the common folk possess the whole power.

\section{The origin of evil things; and that there is no positive evil.}

The Gods being good and making all things, how do evils exist in the world? Or perhaps it is better first to state the fact that, the Gods being good and making all things, there is no positive evil, it only comes by absence of good; just as darkness itself does not exist, but only comes about by absence of light.

If Evil exists it must exist either in Gods or minds or souls or bodies. It does not exist in any god, for all god is good. If any one speaks of a 'bad mind' he means a mind without mind. If of a bad soul, he will make soul inferior to body, for no body in itself is evil. If he says that Evil is made up of soul and body together, it is absurd that separately they should not be evil, but joined should create evil.

Suppose it is said that there are evil spirits :-if they have their power from the gods, they cannot be evil; if from elsewhere, the gods do not make all things. If they do not make all things, then either they wish to and cannot, or they can and do not wish; neither of which is consistent with the idea of God. We may see, therefore, from these arguments, that there is no positive evil in the world. 
It is in the activities of men that the evils appear, and that not of all men nor always. And as to these, if men sinned for the sake of evil, Nature itself would be evil. But if the adulterer thinks his adultery bad but his pleasure good, and the murderer thinks the murder bad but the money he gets by it good, and the man who does evil to an enemy thinks that to do evil is bad but to punish his enemy good, and if the soul commits all its sins in that way, then the evils are done for the sake of goodness. (In the same way, because in a given place light does not exist, there comes darkness, which has no positive existence.) The soul sins therefore because, while aiming at good, it makes mistakes about the good, because it is not Primary Essence. And we see many things done by the Gods to prevent it from making mistakes and to heal it when it has made them. Arts and sciences, curses and prayers, sacrifices and initiations, laws and constitutions, judgements and punishments, all came into existence for the sake of preventing souls from sinning; and when they are gone forth from the body gods and spirits of purification cleanse them of their sins.

XIII. How things eternal are said to 'be made' ( $\gamma i \gamma \nu \in \sigma \theta a \iota)$.

Concerning the Gods and the World and human things this account will suffice for those who are not able to go through the whole course of philosophy but yet have not souls beyond help.

It remains to explain how these objects were never 
made and are never separated one from another, since we ourselves have said above that the secondary substances were 'made' by the first.

Everything made is made either by art or by a physical process or according to some power. ${ }^{1}$ Now in art or nature the maker must needs be prior to the made: but the maker, according to power, constitutes the made absolutely together with itself, since its power is inseparable from it; as the sun makes light, fire makes heat, snow makes cold.

Now if the Gods make the world by art, they do not make it be, they make it be such as it is. For all art makes the form of the object. What therefore makes it to be?

If by a physical process, how in that case can the maker help giving part of himself to the made? As the Gods are incorporeal, the World ought to be incorporeal too. If it were argued that the Gods were bodies, then where would the power of incorporeal things come from? But if we admit it, it follows that when the world decays, its maker must be decaying too, if he is a maker by physical process.

If the Gods make the world neither by art nor by physical process, it only remains that they make it by power. Everything so made subsists together with that which possesses the power. Neither can things so made be destroyed, except the power of the maker be taken away: so that those who believe in the destruction of the world, either deny the existence

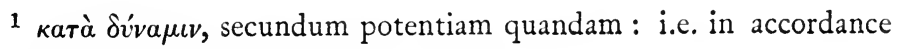
with some indwelling 'virtue' or quality. 
of the gods, or, while admitting it, deny God's power.

Therefore he who makes all things by his own power makes all things subsist together with himself. And since his power is the greatest power he must needs be the maker not only of men and animals, but of Gods, men, and spirits. And the further removed the First God is from our nature, the more powers there must be between us and him. For all things that are very far apart have many intermediate points between them.

XIV. In what sense, though the Gods never change, they are said to be made angry and appeased.

If any one thinks the doctrine of the unchangeableness of the Gods is reasonable and true, and then wonders how it is that they rejoice in the good and reject the bad, are angry with sinners and become propitious when appeased, the answer is as follows: God does not rejoice-for that which rejoices also grieves; nor is he angered-for to be angered is a passion; nor is he appeased by gifts-if he were, he would be conquered by pleasure.

It is impious to suppose that the Divine is affected for good or ill by human things. The Gods are always good and always do good and never harm, being always in the same state and like themselves. The truth simply is that, when we are good, we are joined to the Gods by our likeness to them; when bad, we are separated from them by our unlikeness. And when 
we live according to virtue we cling to the gods, and when we become evil we make the gods our enemiesnot because they are angered against us, but because our sins prevent the light of the gods from shining upon us, and put us in communion with spirits of punishment. And if by prayers and sacrifices we find forgiveness of sins, we do not appease or change the gods, but by what we do and by our turning towards the Divine we heal our own badness and so enjoy again the goodness of the gods. To say that God turns away from the evil is like saying that the sun hides himself from the blind.

\section{$\mathrm{XV}$. Why we give worship to the Gods when they need notbing.}

This solves the question about sacrifices and other rites performed to the Gods. The Divine itself is without needs, and the worship is paid for our own benefit. The providence of the Gods reaches everywhere and needs only some congruity ${ }^{1}$ for its reception. All congruity comes about by representation and likeness; for which reason the temples are made in representation of heaven, the altar of earth, the images of life (that is why they are made like living things), the prayers of the element of thought, the mystic letters ${ }^{2}$ of the unspeakable celestial forces, the herbs and stones of matter, and the sacrificial animals of the irrational life in us.

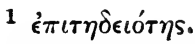

2 On the mystic letters see above, p. 123. 
From all these things the Gods gain nothing; what gain could there be to God? It is we who gain some communion with them.

\section{Concerning sacrifices and other worships, that we benefit man by them, but not the gods.}

I think it well to add some remarks about sacrifices. In the first place, since we have received everything from the gods, and it is right to pay the giver some tithe of his gifts, we pay such a tithe of possessions in votive offerings, of bodies in gifts of 〈hair and) adornment, and of life in sacrifices. Then secondly, prayers without sacrifices are only words, with sacrifices they are live words; the word gives meaning to the life, while the life animates the word. Thirdly, the happiness of every object is its own perfection; and perfection for each is communion with its own cause. For this reason we pray for communion with the Gods. Since, therefore, the first life is the life of the gods, but human life is also life of a kind, and human life wishes for communion with divine life, a mean term is needed. For things very far apart cannot have communion without a mean term, and the mean term must be like the things joined; therefore the mean term between life and life must be life. That is why men sacrifice animals; only the rich do so now, but in old days everybody did, and that not indiscriminately, but giving the suitable offerings to each god together with a great deal of other worship. Enough of this subject. 


\section{That the $W$ orld is by nature Eternal.}

We have shown above that the gods will not destroy the world. It remains to show that its nature is indestructible.

Everything that is destroyed is either destroyed by itself or by something else. If the world is destroyed by itself, fire must needs burn itself and water dry itself. If by something else, it must be either by a body or by something incorporeal. By something incorporeal is impossible; for incorporeal things preserve bodies-nature, for instance and soul-and nothing is destroyed by a cause whose nature is to preserve it. If it is destroyed by some body, it must be either by those which exist or by others.

If by those which exist : then either those moving in a straight line must be destroyed by those that revolve, or vice versa. But those that revolve have no destructive nature; else, why do we never see anything destroyed from that cause? Nor yet can those which are moving straight touch the others; else, why have they never been able to do so yet?

But neither can those moving straight be destroyed by one another: for the destruction of one is the creation of another; and that is not to be destroyed but to change.

But if the World is to be destroyed by other bodies than these it is impossible to say where such bodies are or whence they are to arise.

Again, everything destroyed is destroyed either in form or matter. (Form is the shape of a thing, matter 
the body.) Now if the form is destroyed and the matter remains, we see other things come into being. If matter is destroyed, how is it that the supply has not failed in all these years?

If when matter is destroyed other matter takes its place, the new matter must come either from something that is or from something that is not. If from that-which-is, as long as that-which-is always remains, matter always remains. But if that-which-is is destroyed, such a theory means that not the World only but everything in the universe is destroyed.

If again matter comes from that-which-is-not: in the first place, it is impossible for anything to come from that which is not; but suppose it to happen, and that matter did arise from that which is not; then, as long as there are things which are not, matter will exist. For I presume there can never be an end of things which are not.

If they say that matter 〈will become formless : in the first place, why does this happen to the world as a whole when it does not happen to any part? Secondly, by this hypothesis they do not destroy the being of bodies, but only their beauty.

Further, everything destroyed is either resolved into the elements from which it came, or else vanishes into not-being. If things are resolved into the elements from which they came, then there will be others : else how did they come into being at all? If that-which-is is to depart into not-being, what prevents that happening to God himself? (Which is absurd.) Or if God's power prevents that, it is not a mark of power to be 
able to save nothing but oneself. And it is equally impossible for that-which-is to come out of nothing and to depart into nothing.

Again, if the World is destroyed, it must needs either be destroyed according to Nature or against Nature. Against Nature is impossible, for that which is against Nature is not stronger than Nature. If according to Nature, there must be another Nature which changes the Nature of the World: which does not appear.

Again, anything that is naturally destructible we can ourselves destroy. But no one has ever destroyed or altered the round body of the World. And the elements, though they can be changed, cannot be destroyed. Again, everything destructible is changed by time and grows old. But the world through all these years has remained utterly unchanged.

Having said so much for the help of those who feel the need of very strong demonstrations, I pray the IVorld himself to be gracious to me.

XVIII. Why there are rejections of God, and that God is not injured.

Nor need the fact that rejections of God have taken place in certain parts of the earth and will often take place hereafter, disturb the mind of the wise : both because these things do not affect the gods, just as we saw that worship did not benefit them; and because the soul, being of middle essence, cannot be always right; and because the whole world cannot enjoy the providence of the gods equally, but some parts 
may partake of it eternally, some at certain times, some in the primal manner, some in the secondary. Just as the head enjoys all the senses, but the rest of the body only one.

For this reason, it seems, those who ordained Festivals ordained also Forbidden Days, in which some temples lay idle, some were shut, some had their adornment removed, in expiation of the weakness of our nature.

It is not unlikely, too, that the rejection of God is a kind of punishment : we may well believe that those who knew the gods and neglected them in one life may in another life be deprived of the knowledge of them altogether. Also those who have worshipped their own kings as gods have deserved as their punishment to lose all knowledge of God.

\section{Why sinners are not punished at once.}

There is no need to be surprised if neither these sins nor yet others bring immediate punishment upon sinners. For it is not only Spirits ${ }^{1}$ who punish the soul, the Soul brings itself to judgement : and also it is not right for those who endure for ever to attain everything in a short time : and also, there is need of human virtue. If punishment followed instantly upon sin, men would act justly from fear and have no virtue.

Souls are punished when they have gone forth from the body, some wandering among us, some going to hot or cold places of the earth, some harassed by 
Spirits. Under all circumstances they suffer with the irrational part of their nature, with which they also sinned. For its sake ${ }^{\mathbf{1}}$ there subsists that shadowy body which is seen about graves, especially the graves of evil livers.

XX. On Transmigration of Souls, and bow Souls are said to migrate into brute beasts.

If the transmigration of a soul takes place into a rational being, it simply becomes the soul of that body. But if the soul migrates into a brute beast, it follows the body outside, as a guardian spirit follows a man. For there could never be a rational soul in an irrational being.

The transmigration of souls can be proved from the congenital afflictions of persons. For why are some born blind, others paralytic, others with some sickness in the soul itself? Again, it is the natural duty of Souls to do their work in the body; are we to suppose that when once they leave the body they spend all eternity in idleness?

Again, if the souls did not again enter into bodies, they must either be infinite in number or God must constantly be making new ones. But there is nothing infinite in the world; for in a finite whole there cannot be an infinite part. Neither can others be made; for everything in which something new goes on being created, must be imperfect. And the World, being made by a perfect author, ought naturally to be perfect.

1 i. e. that it may continue to exist and satisfy justice. 
XXI. That the Good are happy, both living and dead.

Souls that have lived in virtue are in general happy, ${ }^{1}$ and when separated from the irrational part of their nature, and made clean from all matter, have communion with the gods and join them in the governing of the whole world. Yet even if none of this happiness fell to their lot, virtue itself, and the joy and glory of virtue, and the life that is subject to no grief and no master are enough to make happy those who have set themselves to live according to virtue and have achieved it.

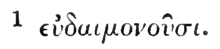




\section{INDEX}

Achaioi, 58, 64.

Aeschylus, 264 $42^{1}$, I 23, I $34^{2}$, I $38^{1}$; Zeus in, $69^{1}$.

Agathos Daimon, Hermes as, 75 .

Agricultural rites, cruelty of, 49 ; in spring, 46.

Agriculture, Religion in, $18 \mathrm{f}$.

Alcmaeon, $133^{2}$.

Alexander as God-Man, I34 f., I 40.

Allegory, in Hellenistic philosophy, I46-50; in Olympian religion, 95 .

Ammianus, I62, I73'.

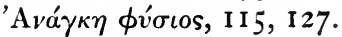

Anaxagoras, 82.

Anaximander, $47^{1}$.

$a ̈ v \delta \rho \epsilon$, duties of, 45 .

Anthesteria, 30-2.

Anthister, $3^{2}$.

Anthropomorphism, in Greek religion not primitive, $24-7$; in Hellenistic age, II8, I20; natural to primitive man, $23-5$, 37 ; result of agricultural rites, 46.

Anthropophuism, 25.

Antipater, I $39^{1}$.

Apaturia, 70.

Apellae, 70.

Apellôn = Apollôn, 70 .

Apbiktor, 42.

Aphrodite, absorbs other Korai, 83.

Apollo, attributes of, 34 ; in Athens, 92 ; in Homer, 65, 66 ; origin and character of, $69 \mathrm{f}$.
Apuleius, initiation of, $\mathbf{2} 29$.

Argos, in Homer, 76.

Aristarchus of Samos, 122.

Aristophanes, 33, 34 $4^{3}, 94^{1}$.

Aristotle, I08, I16, I20 $0^{3}$ I22 $\mathbf{1}^{1}$, I $33,135^{1}$.

Ark of Israel, 88.

Artemis, absorbs other Korai, 83 ; of Ephesus, 78.

Asceticism in antiquity, I63, I8r.

Asclepios, I32.

Astrology, I 23, I99', 200.

Atheïai, why permitted, I75, 2 I I $\mathrm{f}$.

Athena, absorbs other Korai, 83 ; as an ideal, 94; attributes of, 34 ; derivation, $\mathbf{7 2}^{\mathbf{1}}$; in Homer, 65 ; origin and character of, 70-2 ; original in Athens, 92 ; sent to Athenian colonies, 92 ; with owl's head, 38 .

Athenaeus, I $47^{1}$.

Athens, adoption of gods by, 92 ; Athena as Korê of, 7I.

Attis myth, explanation of, I9I ff. 'Attributes', animals as, 34 .

Augustine, St., 501, I6I.

Aurelius, Marcus, I59 f.

Australians, anthropomorphism among, 25 ; disbelief in natural death, 37 .

Avenger, Year as, 47.

Babylon, week of, 123 .

'Barbaroi' as opposed to Hellenes, 57.

Basileus, marriage of, $3 \mathbf{I}$. 
Baunack, J., $\mathbf{7 2}^{\mathbf{1}}$.

Beast-mask, $37 \mathrm{f}$.

Bendis, I3I.

Berôssos, I 24.

Bethe, E., I $3 \mathbf{I}^{1}$.

Bevan, A. A., I $45^{1}$.

Bevan, E., $57^{1}$, I $34^{2}$.

Bortheia, see Ortbia.

Boukolion, 32.

Boundary-stone, Hermes as, 74 .

Bousset, W., II $9^{1}$, I $27^{2}$, I $3 I^{3}$, I 43 , I $45^{2}$.

Bull, blood of, 34 ; in preHellenic ritual, $34-6$; mask, 38 ; why sacred, 33 .

Camel, sacramental eating of, 36 . Chadwick, H. M., 66, $77^{2}, 78$.

Chaldaeans, I24, I3I.

Christian era, characteristics of, I03 $\mathrm{f}$.

Christianity, belief in end of world by fire, I74; compared with Greek Philosophy, I05; early, organization of, $178 \mathrm{f}$.; rejection of gods, I66; struggle with Paganism, I79.

Christmas, Father, 29.

Chrysippus, I IO ${ }^{1}$, I I $5^{3}$, I I 7, I $_{2} 0^{3}$, I $25^{1}, 126^{1}, 139,146$.

Chthonioi, as oracles, 5 I ; sacrifice to, 28 ; snake lives among, 33.

Cicero, $4 \mathrm{I}^{3}, \mathbf{1} 25^{2}, \mathbf{1 2 7}, \mathbf{1} 33^{2}$, I 39 .

Circumcelliones, $5^{1}$.

Classification according to age, $45 \mathrm{f}$.

Cleanthes, I I 5, I22, I46.

Cleisthenes, constitution of, 87 .

Collitz and Bechtel, $72^{1}$.

Command, the religious, $19^{1}$.

Congress of Religions, Third International, 23.

Constantine, vision of, $4 \mathrm{I}$.

Constantius, I64, I67.
Cook, A. B., 301, 38, 392, 67 $7^{1}$, $68,7^{1}, 85^{1}$.

Corinna, $6 \mathrm{I}^{2}$.

Cornford, F. M., $47^{1}$.

Cornutus, I 47.

Corpus Hermeticum, I29, 143.

Crates, I46.

Creed, value of a, $15^{8}$.

Crete, religion of, $85^{1}$.

Cumont, F., $50^{1}$.

Cynics, I48.

Dadouchos, 38 .

Dance, religious, $4^{\mathrm{I}}-3$.

Darius as God, I34.

Davenport, Professor F. M., $4 \mathbf{I}^{1}$.

Davids, Mrs. Rhys, $23^{2}$.

Davy, G., I9 1 .

Dead, worship of, 82 .

Deification, origin of, 39 .

Delphi, bull at, 34 .

Demeter, and Korê in Athens, 92; in Thesmophoria, $29 \mathrm{f}$.

Demetrius of Phalerum, II $3^{1}$.

Democritus, I09, I332.

Dharma, 23.

Diadochi, I35.

Dialect in literature, change of, $6 \mathrm{I}$.

Diasia, 27-9.

Dicaearchus, 108.

Didymus, 108.

Dieterich, A., $3 \mathrm{I}^{2}, 37^{1}, 43^{2}$, I26, I $3 \mathrm{I}^{3}$.

Dike, possessed by King, 39 .

Dio Cassius, 123.

Diodorus, 124.

Diogenes Laertius, $1 \mathbf{2 0}^{\mathbf{3}}, \mathbf{1}^{6} \mathbf{6}^{1}$.

Diogenes of Oenoanda, I5 I f.

Dione, ousted by Hera, 75 .

Dionysus, at Anthesteria, $30 \mathrm{f}$. ; attributes of, 34; compared with Alexander, I40; in Athens, 92. 


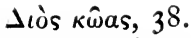

Dithyramb, 42 .

Dittenberger, W., 29 ${ }^{1}$, $137^{1}$.

Divination, belief in, $125 \mathrm{f}$.

Divine animal, in ritual, 30 , 33-5; origin of, 35 .

Doutté, E., 4I, 42 .

Drômena, spring, $44 \mathrm{ff}$.

Durkheim, Professor Émile, I $9^{1}$.

'Dying god', I44.

Earth, as divine, II7 ; as Kourotrophos, 43.

Edda, gods of the, 79 .

Egyptians, deification of material objects, I90; gods of, 37 .

Ekstasis, I 30 .

Elean gods, 63 .

Enthousiasmos, I3o.

Eôs, connexion with Athena, 7r.

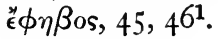

Epicureanism, exposition by

Diogenes of Oenoanda, I5 I f.; repudiated astrology, I 25 .

Epicurus, I09:., II6, I20 ${ }^{3}$, I2I, $176^{1}$.

Epiphanius, $145^{2}$.

Eratosthenes, Iog.

Euêtheia, I6.

Euhemerus, II9, I4I.

Euripides, $26^{4}, 43,73^{4}, 80^{1}, 94^{1}$, $96,115^{1}, 123,132$.

Eusebius, $4 \mathbf{I}^{\mathbf{5}}$.

Eusebius the Ionian, 182.

Evangelical movement, 58.

Evans, Sir A., 34, 85 .

Evil, non-existent, I 7 I, 203 f.

Expurgation, of legends, $80^{\mathbf{1}}$; of mythology, $95 \mathrm{f}$. ; of rites, $8 \mathrm{I}$ f.

Failure, sense of, I03 f., et III passim.
Faith, 2 I.

Farnell, Dr. L. R., $32^{1}, 34^{1}, 62$, $69^{2}$.

Fate, I 27 ; worship of, I $5 \mathrm{f}$.

Ferguson, W. S., I $33^{1}$.

Fertility of earth and tribe conceived as one, $43 \mathrm{ff}$.

Fick, A., 6 $\mathbf{I}^{2}$.

Fire, heavenly, I I 7 .

First Cause, and essence of God,

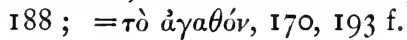

Florus, $4 \mathrm{I}^{3}$.

Forbidden Days, 2 I 2.

Fortune, beneath Moon, I27 ; worship of, I I 2-I 4, 201.

Frazer, Dr. J. G., $30^{1}, 3^{1}, 40$, $50^{1}, 134^{1}$.

French Revolution, 58 .

Gaertringen, Hiller v., $32^{2}$.

Gardner, Professor P., 77 $129^{2}$.

Geffcken, J., I8 $\mathrm{I}^{1}$.

Gennep, A. Van, $44^{3}$.

Gerontes, $5 \mathrm{I}$.

Ghosts, at Anthesteria, 3I, $4^{8}$.

Gladstone, Mr., 25.

Gnosticism, I28, I3 I, I43-6.

God, conception of, in savage tribes, 23.

God-Man, as King, I33-40; as

Redeemer, I4I-6.

Gods, appearing in battle, 4I ;

Cosmic and Hypercosmic, I94 f. ; existence admitted by Stoics and Epicureans, Iog f.; man's relation to, I $7 \mathrm{I}$ f., $206 \mathrm{f}$. ; nature of, $\mathrm{I} 87 \mathrm{f}$.

Gomperz, T., $69^{1}$.

Gorgon, head worn by Athena, 38.

Gregory, 162.

Gruppe, Dr., 32 $2^{1}, 69^{2}, 70^{1}, 71^{1}$, $72^{1}, 7^{61}$. 
Hagia Triada, sarcophagus of, 34.

Halliday, W. R., $46^{2}, 47^{1}$.

Hallucination, power of, $4 \mathrm{I}$.

Harnack, A., I 78 .

Harrison, Miss J. E., 27-53 passim, $63^{1}, 69^{1}, 70^{1}, 75^{2}, 76$, I I 8, I 28.

Hartland, E. S., 23.

Haverfield, Professor F. J., I08.

Hecataeus, I I9.

Heimarmenê, II 5, 199.

Helen, Korê as, I I9.

Hellenes, conquered tribes took name of, 60; distinguished from ' barbaroi', 57 ; no tribe of, existing in historical times, 59 ; same as Achaioi, 58.

Hellenism, as standard of culture, 59 ; strife against barbarism, 80 . Hellenistic, Age, documents and sources, 106 ; stage of Religion, 17.

Hephaistos, 66.

Hera, attributes of, 34 ; derivation of, $76^{1} ;$ origin and character of, $75 \mathrm{f}$. ; with cow's head, 38.

Heraclitus, I47, $148 \mathrm{f}$.

Herakles, connexion with Hera, 76 ; in lion-skin, 38 .

Hercules, becomes a god, I39.

Heretics, burning of, 52,53 .

Hermêneis, Planets as, I 24 .

Hermes, as Mediator, $\mathbf{1} 32$; origin and character of, $74 \mathrm{f}$.; liturgies, I3I f.; and planet Mercury, $\mathbf{I} 20$.

Hermetic lore, transmission of, I32.

Herodotus, $4 \mathrm{I}^{4}, 57,59,60^{1}, 62$, 70,107, I 59 .

'Heroes', philosophers as, I34; tombs used for oracles, $5 \mathrm{I}$.
Heroic Age, 66 f., 77.

Hesiod, 62, I $3^{1}$; attempt to systematize religion, 84 f.; religious system compared with Homer's, 85 .

High Church movement, 58.

Hippocrates, I09.

Hippolytus, I 27, I 43.

Hippothoon, 26.4

Hoffmann, Dr. O., 6 $\mathrm{I}^{2}, 7 \mathrm{I}^{2}$.

Hogart', D. G., $3^{8}$.

Homer, Achaian and aristocratic by tradition, 78 ; allegorical interpretation of, I49; Aphrodite and Ares in, 76 f.; Argos in, 76; Athena's position in, $\mathbf{7 2}^{\mathbf{1}}$; brought to Athens, 6I; date of written, $67^{\mathbf{1}}$; expurgation in, 68, 75; Hera in, 76; Hermes in, 75; Hymns, 69; Iliad, $4^{81}$; mainly Ionian, 79 ; not primitive, $23 ; O d ., 75^{1}$; Poseidon prominent in, 73; produced religious reformation, 78-87 ; religious system compared with Hesiod's, 85 ; unCretan, $85^{\mathbf{1}}$; word ' barbaroi' does not occur in, $60^{2}$.

Hosiôtêr, bull as, 35 .

Hubert and Mauss, MM., $173^{2}$. Hubris, committed by Year, 47 . Humility based on 'asthenic emotion', 104'.

Idealism in Stoicism, Gnosticism, \&c., I $49 \mathrm{f}$.

Idols, defence of, $98^{1}$.

Infanticide, I6I.

Initiations, Hellenistic， I28-33; tribal, $44 \mathrm{ff}$.

Ionians, Apollo Patrôos as god of, 70 .

Iranes, $45,4^{6}$.

Irenaeus, I I $9^{1}, \mathrm{I}_{3} \mathbf{I}^{2}$. 
Iris, 75 .

Isis, I32 ; derivation of, I47.

Jacoby, $\mathbf{I}_{4} \mathbf{I}^{\mathbf{1}}$.

Jaldabaoth $=$ Saturn, $\mathbf{1 2 7}$.

Jars, Wine and Funeral, $3 \mathbf{I}$.

Jason, 76 .

Javan, sons of, 60 .

Jews, gave up sacrifice, $\mathbf{1 7 2}$; rejected Planet week, I23.

Julian, as ascetic, I6 3, I 81 ; belief in gods, I66 f., I68; friendship with Sallustius, I63-5; on the Sun, I9 $\mathbf{I}^{\mathbf{1}}$.

Justin, $84^{1}$.

Juvenal, I I 3 .

Kaibel, 80 1 .

Kant, I 6 .

$\kappa \epsilon i \rho \omega$, connexion with кov̂pos, 44 .

Kêres, 48.

Kern, O., $35^{2}$.

King, I., $43^{2}$.

Kings, divinity of, I33 ; divine, titles of, 136 .

Koios, 147.

Korai, crystallized into types, $83 \mathrm{f}$.

Korê, as universal religious ideal, I $8 \mathrm{f}$. ; in Thesmophoria, $29 \mathrm{f}$.; Rape of, 193.

Kosmokratores, $126 \mathrm{ff}$., 145.

Kourêtes, I $3 \mathbf{I}$; Hymn of, 431, 44.

Kouroi, crystallized into types, $83 \mathrm{f}$.; dance of, 42 .

Kouros, Megistos, as Zeus, Apollo, \&c., 43, 69, 70 ; Sun as, 44 .

Kourotrophoi, Earth, 43; nymphs and rivers, 44 ; Moon, 44 .

кра́тos and Bía, of $\theta \epsilon o ́ s, 39, \mathbf{1} 38^{1}$.
Kronos, explanation of myth, I90; ousted from Olympia by Zeus, 64 .

Lake Regillus, gods at, $4 \mathrm{I}$.

Lang, A., $30^{\mathbf{1}}, 37^{\mathbf{1}}$.

Langloh Parker, Mrs., 25.

Language, mystic treatment of, 147.

Leaf, W., $5^{1}, 67^{1}$.

Leto, 69, 801.

Lincoln, Abraham, 58 .

Lucian, Icaro-Menippos, 281.

Lucretius, 53 .

Lysander, I 36 .

Macedon, Gods of, II 2 ; rise of, I07.

Mackail, Professor J. W., 6r.

Macrobius, I 27.

Magnesia, bull-ritual at, 35 .

Mana, 33, 37-9, 48, 50, I381.

Man-god, rejection of, by Philosophy, 175; worship of, 82, I 33-46.

Marathon, heroes at, $4 \mathrm{I}$.

Marett, R. R., I04 ${ }^{1}$.

Margoliouth, Professor, I $48^{1}$.

Marriage, Sacred, 3I f., I3I.

Martyrs, voluntary, 49.

Mate, $45^{1}$.

Maximus of Tyre, $98^{1}$.

Mayer, M., $64^{2}$.

McDougall, W., IO4 ${ }^{1}$.

Mediator between God and worshipper, I 3 I f.; Saviour as, I $\mathbf{4}^{2}$.

Medicine-king, as $\theta$ єós, 39, I 33 ; differentiation from real $\theta \epsilon o ́ s$, 40 ; knows what is Themis, $5 \mathrm{I}$; large families of, $39^{1}$; powers of, 39 .

Meilichios, half-anthropomorphic, 40 ; in the Diasia, 27-9; 33 . 
Meister, R., $\mathbf{7 2}^{\mathbf{1}}$.

Melanippe, 132.

Melissus, $133^{2}$.

'Men's House', I3I.

Meyer, Ed., I35 ${ }^{1}$.

Migrations, $64,86$.

Mind, nature of, 197.

Minoan element in Greek life, $85^{1}$.

Minos, bull of, 34 ; as bull-god, 37.

Minucius Felix, I66, I74.

Mithraism, 35, 128.

Mithras, as Mediator, I3I f. ; as Sun, I20; Liturgy, I26, I29, I33.

Mommsen, August, 27 $, 31^{1}, 32^{1}$, $38^{2}$.

Monotheism in classical period, $25 \mathrm{f}$., $90 \mathrm{f}$.

Moon, divinity of, I $7 \mathrm{ff}$.

Morals in antiquity, $16 \mathrm{I} \mathrm{f}$.

Moret, $37^{1}$.

Mountain, sacred, 40.

Mülder, D., 721 $76^{2}$.

Müller, H. D., $76^{2}$.

Murray, G., $39^{1}, 42^{1}, 46^{2}, 67^{1}, 69^{1}$, $82^{1}, 86^{1}, 133^{1}, 138^{1}, 162^{3}$.

Music of the Spheres, I22.

Myres, Professor J. L., $5^{81}$.

Myths, Sallustius' treatment of, I68 f., I 88-93: why divine, I $88 \mathrm{f}$.; five species, I90; explanation of examples, I9I-3.

Naassenes, I27, 143.

Nature-religion, danger of humanizing, $88 \mathrm{f}$.

Nazarius, $4 \mathrm{I}^{\mathbf{5}}$.

Neo-Platonism, 165.

Nilsson, M. P., $32^{2}, 35^{2}, 44^{3}$.

Nilus, St., 36 .

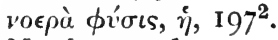

Norden, I $40^{1}$.
Ogdoas, 128.

Old Men, as authorities on Themis, 5 I $\mathrm{f}$.

Olympia, $63 \mathrm{f}$.

Olympian gods, brought by Northern invaders, 64 ; character of, $65-77$; coming of, 62 ; explained as deified mortals, $\mathbf{I} 40$; firmly established in fifth century в. C., 24 ; not present at Diasia, \&c., 32 ; not primary, 27 ; origin of, $36 \mathrm{ff}$. ; substitutes for: Fortune and Fate, I I I-I6, Heavenly bodies, I 6-33, Soul, I33-46; why so called, $63 \mathrm{f}$.

- religion, achievements of, $93 \mathrm{ff}$; ; aims of, 78-87; beauty of, $93 \mathrm{f}$.; failure of, 87-93, I07.

Olympieum, 63 .

Olympus, Mount, $63 \mathrm{f}$.

Oracles, $5 \mathrm{I}-3$.

Oreibasia, 42 .

Oreibates, 42.

Organization, social, $202 \mathrm{f}$.

Orphic Hymns, $44^{1}, 84^{1}, \mathrm{I} 28$.

Ortbia, 45.

Osiris, derivation of, 147 .

Othin, $68^{2}$.

Ovid, Metam., $7 \mathbf{I}^{2}$.

Pagan, prayer, a, I 82 f.; reaction, chap.iv.

Paganism, final development of, I $77 \mathrm{f}$.; struggle with Christianity, $179 \mathrm{f}$.

Palladion, $7 \mathrm{I}$.

Pallas, Athena as, 71, 92 ; giant, 72.

Panaetius, 125.

Panathenaia, Homer recited at, 6r.

Paribeni, R., $34^{2}$. 
Paris myth, explanation of, I9I. Parmenides declares God is One, $25,26^{1}$.

Paul, St., 2I, 37, 47, 80, 104, I I 8 , 129, 138 ; and Barnabas, 142 ; his religious system, $145 \mathrm{f}$.

Pausanias, $4 \mathrm{I}^{4}, 63^{1}, 64^{2}, 73^{3}, 75$.

Payne, E. J., $43^{2}, 44^{2}$.

'Pearl', the, 145 .

Pelasgians, Athenians as, 59 ; gods of, 62 .

Pelopidas, $80^{1}$.

$\pi \hat{\epsilon} \mu \pi \tau o \nu$ $\sigma \hat{\omega} \mu \alpha, 117,197^{1}$.

Pericles, Funeral Speech of, 96.

Perseus of Macedon, defeat of, I $13^{1}$.

Phallic, gods, 62, 74; rites expurgated, 8I.

Pharmakos, 48.

Philo, I6I f.

Philolaus, $146^{1}$.

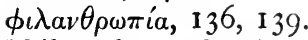

Philosophy, Greek, compared with Christianity, 105.

Pigs, sacrifice of, 29; sacrifice to, 30 ; why sacred, 33 .

Pindar, $45^{2}, 7 \mathrm{I}^{2}$.

Pisistratus, $60 \mathrm{f}$. $63,67^{1}, 73$.

$\pi i \sigma \tau \iota s, 2 \mathrm{I}$.

Planets, seven, history and worship of, 1 20-33.

Plato, $26^{4}, 70^{2}, 73^{1}, 96$, 109, II920, I33 f., I44, I48, I6I, I70, I $9^{1}, 202^{1}$.

Pliny, I I4, I 39 .

Plotinus, $130^{1}$.

Plutarch, $41^{4}, 46^{1}, 48^{2}, 73^{3}, 80^{1}$, I I $3,119,120^{1}$.

Polis, collapse of, 107 ; higher ideal than Nation, I08; religion of, 9I, $96 \mathrm{f}$; replaces Tribe, $86 \mathrm{f}$.

Polybius, II 3 .

Porphyry, $130^{i}$.
Poseidon, origin and character of, $73 \mathrm{f}$.

Posidonius, 108, I203, I $39 \mathrm{f}$.

Precariousness of ancient life, 49. Predestination, 126.

Presbiston, $5 \mathrm{I}$ f.

Preuss, Dr., 16.

Proclus, 124, $197^{2}$.

Projection, Father Christmas as d, 29 ; in magic ceremonies, 32 ; of collective emotion as god, $4 \mathrm{I}-3$.

Pronoia, Stoic belief in, 125.

Prophecy, belief in, $125 \mathrm{f}$.

Protomê, 38 .

Providence, $198 \mathrm{f}$.

Psychopompos, Hermes as, 74.

Ptah, I32.

Ptolemy, Epiphanês, 137 f.; Philadelphus claims divine honours, I 35 .

Punishment, why not immediate, 212.

Pythagoras, $12^{1}, 148$.

Reformation, the, 58 .

Reinach, A. J., $39^{2}$.

Reinach, S., $39^{2}, 88^{1}, 172^{1}$.

Re-incarnation, $3 \mathrm{I}$.

Reitzenstein, I3 $1^{3}$, I43.

Religion, crimes committed in the name of, 22; description of, 18-22; distinguished from superstition, 97 f.; Greek, significance of, 15 ; reformed by Homer : (expurgation of rites, $8 \mathrm{I}-2$; systematization, $82-5$; adaptation to new social order, 85-7) trend of, in Hellenistic age, $108 \mathrm{f}$.; work of the tribe, I $9^{1}$.

Reutershiold, $35^{3}$.

Ridgeway, Professor, $5^{81}, 73^{2}$. 
Rivers, Dr., $45^{1}$.

Robertson Smith, Dr., 35 f., $38^{1}$.

Rodin, 24.

Rome, as a Polis, 108.

Roosevelt, T., 58.

Ruah, II8.

Sacramental feast, $35 \mathrm{f}$.

Sacrifice, human, 49 f., $80^{1}$; reason for, $172 \mathrm{f}$., $207 \mathrm{f}$.

St. Gaudens, 24, 27.

Sallustius, $119^{2}, 146$; analysis of religious views, $167-76$; creed of, I87-2I4; friendship with Julian, 163-5 ; Neo-Platonist, I65.

2 Sam., $88^{1}$.

Sarpedon, 48 .

Saturn, I 27.

Saviour, as Son of God and Mediator, I42 f., I 44 ; dying, 50 ; Gnostic, I $43-5$; YearDaimon as, 47 .

Schleiermacher, IOt $^{1}$.

Schurtz, $44^{3}$.

Schwartz, Ed., I $40^{1}$.

'Second Man', I 44 f.

Seeck, O., 501, $72^{1}$.

Selene, Korê as, II 9 .

Siloam, Tower of, II I.

Simon, $119^{1}$.

Sin, pollution of, 47,49 .

Slavery, I6I.

Snake, supernatural, 33.

Sophocles, 264, 104.

Sopbrosynê, I33, I82.

Soul, divinity of, I16 f., 133-46; nature of, $197 \mathrm{f}$.

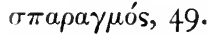

Sparta, initiation ceremonies in, $45 \mathrm{f}$.

Sphere, Fixed, 196.

Stars, divinity of, 116-33.
Steiner, H., 24.

Stobaeus, 182 .

Stoicheia, divinity of, $1 \mathbf{1 7}$; planets as, I22; seven vowels in Greek A B C, I23.

Stoics, $120^{2}, 125$.

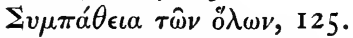

Sun, = both orb and ray, I9I ${ }^{1}$; divinity of, II7-20; in agriculture, 44 .

Superstition, a bad form of religion, 20; distinguished from religion, $97 \mathrm{f}$.; flourishes in unstable societies, II3; rejected by Stoics and Epicureans, IIO.

Swift, Modest Proposal, $2 \mathrm{I}^{\mathbf{1}}$.

$\mathcal{T} a b u, 4^{8} \mathrm{fi}$.

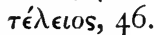

Teletai, 46 .

Themis, 39, $50 \mathrm{ff}$.

Theodoret, I 65 .

Theophrastus, I 24.

$\theta \epsilon o ́ s=\theta \epsilon \sigma o ́ s, 39 ;$ use of the word by poets, 26 .

Theseus in Athens, 92.

$\theta \epsilon \sigma \mu o^{\prime}$, derivation of, $29^{1}$.

Thesmophoria, $29 \mathrm{f}$.

Thesmophoros, 29 f., 33, 40.

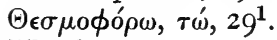

Thoth, I32.

Thucydides, 59, I 59.

Thumb, A., 6I ${ }^{2}, 64^{1}$.

Tomb-oracles, $5 \mathrm{I}$.

Tombs of kings, 79 .

Transmigration of souls, $2 \mathrm{I} 3$.

Tribe, religion of, $82 \mathrm{f}$., $85 \mathrm{f}$.; replaced by Polis, $86 \mathrm{f}$.

$\tau$ гíros $\sigma \omega \tau \eta \dot{\rho} \rho, 47,50,144$.

Troy, Poseidon's connexion with,

73.

Tyrtaeus, $138^{1}$. 
Uncharted region of experience, I 8 ff., I 52, I 83 .

Urdummbeit, 16, 62, 93.

Uzzah, 88.

Vandal, $58^{2}$.

Vegetarianism, $2 \mathrm{I}^{1}$.

Vegetation-spirit, 46 .

Verrall, A. W., $29^{1}$.

Vice, definition of, 202.

Virgin, fallen, Korê as, 118 f., I 45 .

Virtue, definition of, $201 \mathrm{f}$; ; its own reward, 176, 214; rewards of, I75, 214 .

Visions, I $29 \mathrm{f}$.

Vowels as signs of Seven Planets, I 23, I 26, 207.

Warde Fowler, W., $3^{1}{ }^{1}$.

Webster, H., $44^{3}$.

Week of seven days established, I 23.

Wendland, P., I $37^{1}, 139^{2}$.

Wide, S., $92^{1}$.
Wilamowitz-Moellendorff, U.von, $61^{2}, 69^{3}, 79$.

Winckelmann, 24.

Witches, burning of, $2 \mathrm{I}^{1}, 53$.

Woodward, A. M., $46^{1}$.

World, eternal and indestructible, 170, 174, 196, 209-II ; origin of, 204-6.

Xenophanes, on the nature of God, 26.

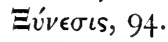

Year-Daimon, 46, 47 .

Zeller, E., I09.

Zeno, Iog f., II $5,133^{2}$.

Zeus, Aphiktor, 42; attributes of, 34 ; conquered Cronos, 65 ; in Magnesia bull-ritual, 35; Meilichios, 27-9; origin and character of, $68 \mathrm{f}$. ; sacrifice at Diasia not given to, 28 .

Zoilus, I 48 .

Zoroastrianism, $58^{1}, 127^{2}$. 
Published by William Heinemann

HISTORY OF ANCIENT GREEK LITERA'TURE. I897. $6 s$.

CARLYON SAHIB: A Play. I899. Is. 6d. ANDROMACHE: A Play. Igoo. Is. $6 d$.

Published by the Clarendon Press

EURIPIDIS FABULAE: Brevi Adnotatione Critica Instructae, Vols. I, II, III. I90I-I909. From 3s. each. India Paper, one volume, I2s. $6 d$.

'THE RISE OF 'THE GREEK EPIC. Second Edition. I9I I. 7s. 6d. net.

'THE INTERPRETA'TION OF ANCIEN'T GREEK LITERATURE. Inaugural Lecture at Oxford. I909. Is, net. NEFREKEPTA : An Egyptian Story done into Verse. I9Io. 4 s. 6 d. net.

Published by George Allen \& Sons.

EURIPIDES: Hippolytus; Bacchae; Aristophanes' 'Frogs'. With an Appendix on The Lost Tragedies of Euripides, and an Introduction on The Significance of tile Bacchae in Athenian History, and 12 Illustrations. Fifth Edition. $7 s .6 d$.

\section{ALSO SEPARATELY}

PLAYS. Translated into English Rhyming Verse, with Explanatory Notes.

Hippolytus. I4th Thousand.

BACChAE. Ioth Thousand.

The Trojan Women. gth Thousand.

Electra. IIth Thousand.

MEDEA. 8th Thousand.

IPHIGENIA in TAURIS. 6th Thousand.

Tile Frogs of Aristophanes. Ioth Thousand.

Edipus Tyrannus of Sophocles. 8th Thousand.

Separate Plays, Is, or $2 s$. 





\section{DATE DUE}

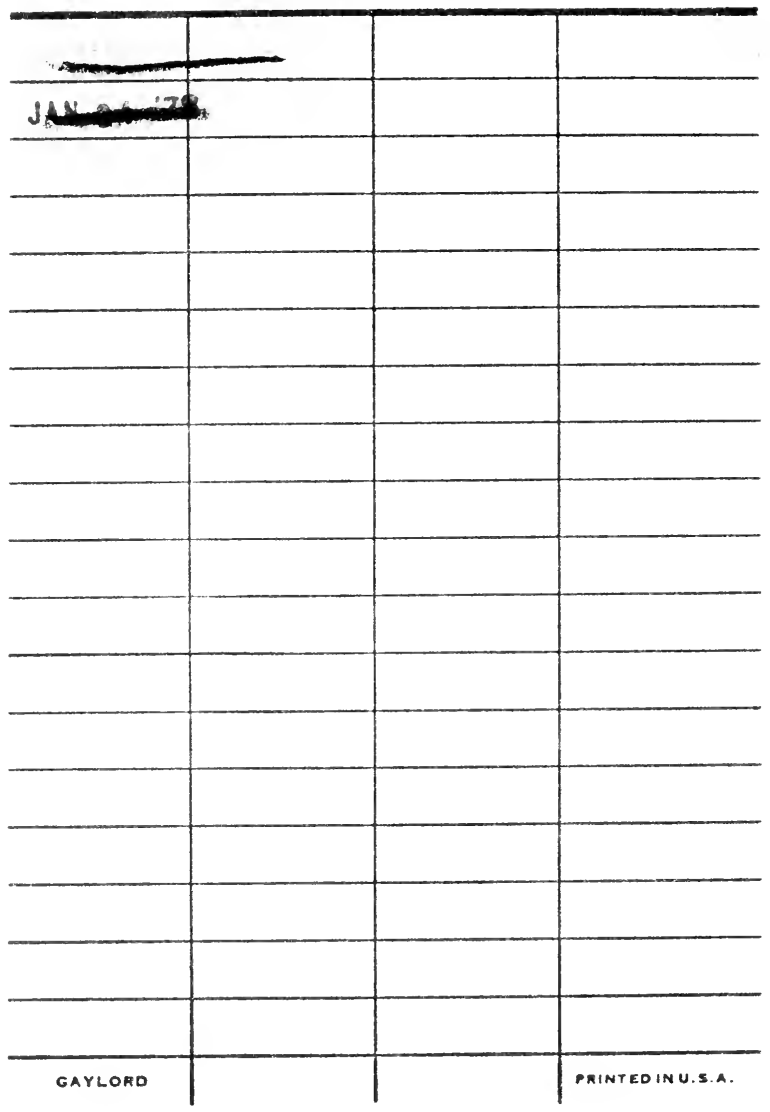




$$
\text { • }
$$


Four stages of Greek religion: studies

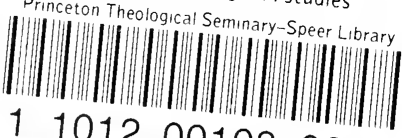

11012001080631 